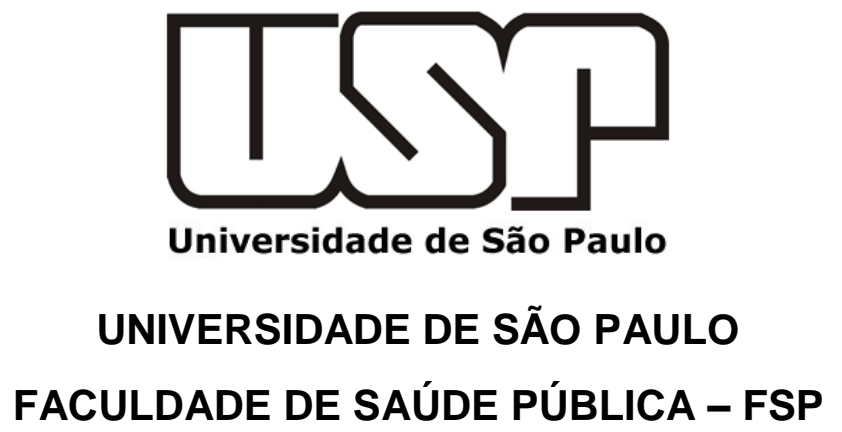

Tatiana Oliveira Moneró

Aplicação do GHS na indústria de saneantes: Roteiro para classificação de produtos saneantes

Versão Corrigida

São Paulo

2016 
TATIANA OLIVEIRA MONERÓ

\section{Aplicação do GHS na indústria de saneantes: Roteiro para classificação de produtos saneantes}

Dissertação apresentada ao

Programa de Mestrado Profissional em Ambiente, Saúde e Sustentabilidade da Faculdade de Saúde Pública da Universidade de São Paulo para obtenção do título de Mestre Profissional em Ambiente, Saúde e Sustentabilidade.

Orientador: Prof. Dr. José Marçal Jackson Filho

São Paulo

2016 
Autorizo a reprodução e divulgação total ou parcial desse trabalho, por qualquer meio convencional ou eletrônico, para fins de estudo e pesquisa, desde que citada a fonte.

Moneró, Tatiana Oliveira

Aplicação do GHS na indústria de saneantes: Roteiro para classificação de produtos saneantes / Tatiana Oliveira Moneró. - 10 de Agosto de 2016.

140f. : il.

Orientador: Prof. Dr. José Marçal Jackson Filho

Dissertação (Mestrado) - Universidade de São Paulo, 2016

1. GHS. 2. Saneantes. 3. Saúde do Trabalhador I. Filho, José Marçal Jackson II. Aplicação do GHS na indústria de saneantes: Roteiro para classificação de produtos saneantes 
Nome: MONERÓ, Tatiana Oliveira

Título: Aplicação do GHS na indústria de saneantes: Roteiro para classificação de produtos saneantes

Dissertação apresentada ao Programa de Mestrado Profissional em Ambiente, Saúde e Sustentabilidade da Faculdade de Saúde Pública da Universidade de São Paulo para obtenção do título de Mestre Profissional em Ambiente, Saúde e Sustentabilidade.

Aprovado em:

\section{Banca Examinadora}

Prof. Dr. Instituição:

Julgamento: Assinatura

Prof. Dr. Instituição: Julgamento: Assinatura:

Prof. Dr. Instituição:

Julgamento: Assinatura: 


\section{AGRADECIMENTOS}

Agradeço à toda minha família pelo apoio recebido desde o início, principalmente minha mãe, Tânia, que é minha maior inspiração e exemplo de determinação.

Agradeço ao meu noivo Rodrigo pela paciência, pela compreensão, pelo incentivo e pela ajuda que sempre me deu, principalmente nos quesitos "computacionais".

Agradeço às companheiras de sala e novas amigas que o mestrado me deu, Laís e Nelly. Sem vocês nada teria sido igual!

E, principalmente, agradeço ao meu orientador, Marçal, por aceitar minhas propostas e não ter desistido de mim quando precisei viajar. Agradeço pelas suas palavras cheias de motivação que sempre me colocaram pra cima e não me deixaram desistir. 


\section{RESUMO}

MONERÓ, T.O. Aplicação do GHS na indústria de saneantes: Roteiro para classificação de produtos saneantes. 2016. 138f. Dissertação (Mestrado) Faculdade de Saúde Pública, Universidade de São Paulo, São Paulo, 2016.

Com o aumento gradativo da tecnologia e da necessidade de consumo humana, a cada dia são desenvolvidos novos produtos e novas substâncias. Além dos benefícios desta modernização, surgem as preocupações relacionadas com o uso excessivo de produtos químicos. Muitos produtos químicos possuem potencial de causar efeitos adversos à saúde humana e ao meio ambiente e, por isso, de uns anos pra cá, passou a ser essencial e obrigatória a comunicação dos riscos advindos desses produtos dentro do ambiente de trabalho. O GHS, um sistema globalmente harmonizado de classificação e rotulagem de produtos químicos foi criado pela ONU para trazer critérios e elementos harmonizados para a comunicação desses perigos. A identificação dos perígos do GHS é um procedimento complexo e muito difícil para as empresas, com destaque para aquelas de menor porte, como é o exemplo do setor de saneantes, que é, em sua maioria, constituido por micro e pequenas empresas. Além de terem a obrigação de seguir os requisitos estabelecidos pelo GHS, os fabricantes de saneantes seguem as exigências da Anivsa para comercialização de seus produtos. Combinando os requisitos da Anvisa com os do GHS, percebe-se que algumas classes e categorias de perigo do GHS não se aplicam para saneantes. Com isso, o propósito desse trabalho foi desenvolver um roteiro para classificação do GHS destinado especificamente ao setor de saneantes. Para o desenvolvimento do roteiro foram elaborados fluxogramas de decisões lógicas com requisitos do GHS e exigências da Anvisa. $O$ trabalho atingiu o seu objetivo como um todo, criando um modelo de roteiro para aplicação do GHS para o setor de saneantes. Após a aplicação do roteiro em um produto exemplo e após as discussões levantadas, percebeu-se que alguns detalhes poderiam ser melhor incorporados no roteiro. Apesar do roteiro possuir suas limitações e algumas imperfeições, acredita-se que possa contribuir de alguma forma para o setor. Ao invés dos profissionais consultarem o GHS como um todo, um guia simplificado, resumido e com particularidades do setor, pode fazer com que as indústrias tenham uma maneira mais fácil de aplicar o GHS e, assim, contribuir para que as classificações sejam realizadas de uma maneira correta.

Palavras-chave: GHS; Saneantes; Saúde do Trabalhador; Comunicação de Perigos 


\begin{abstract}
MONERÓ, T.O. GHS implementation for sanitizer industries: Classification Guide for cleaning products. 2016. 138f. Dissertação (Mestrado) - Faculdade de Saúde Pública, Universidade de São Paulo, São Paulo, 2016.
\end{abstract}

With the technology gradual increase and the need of human consumption every day new products and new substances are developed. In addition to the benefits of this modernization, there are concerns about the excessive use of chemicals. Many chemicals have potential to cause adverse effects on human health and the environment and, therefore, a few years ago the risk communication of these products in a workplace became essential and mandatory. The GHS, a globally harmonized system of classification and labeling of chemicals was created by the UN to bring harmonized criteria and elements to communicate these dangers. The GHS hazard identification is a complex and difficult procedure for the industries, especially those ones that are small, as sanitizer sector for example, which is mostly composed of micro and small companies. In addition to have the GHS obligation the sanitizer manufacturers follow the Anvisa regulation as well. Combining the Anvisa requirements with GHS ones, it is clear that some GHS hazard classes and categories do not apply for cleaning products. Thus, the purpose of this study was to develop a GHS classification guide intended specifically for sanitizer industry. To build the guide flowcharts were developed with logical decisions with GHS and Anvisa requirements. This study reached its goal as a whole, creating a guide model for GHS implementation in sanitizer industries. After the guide application in a product sample and the discussions, it was noted that some details could be better incorporated into the script of the guide. Although the guide has some limitations and imperfections, it can contribute in some way to the industry. Instead of a professional consulting GHS as a whole, a simplified, summarized and with the sanitizer particularities guide may give to the industries an easier way to apply the GHS contributing to the correct classifications.

Keywords: GHS; sanitizer; Worker's health; Hazard Communication 


\section{LISTA DE FIGURAS}

Figura 1 - Elementos de classificação e comunicação do GHS. Adaptado de ABNT 2005, (MATTA, 2011)

Figura 2 Comparação entre a classificação de toxicidade para um produto com uma DL50 de 257,0 mg/kg entre os países usando seus sistemas de classificação antes da harmonização pelo GHS. Adaptado de Mercosul (2013) .

Figura 3 Diferentes pictogramas presentes no rótulo de um mesmo produto antes da harmonização pelo GHS. Adaptado de Mercosul (2013) .27

Figura 4- Pictogramas harmonizados pelo GHS (MERCOSUL, 2013) 31

Figura 5- Quantidades de registros de números CAS no decorrer dos anos.

Adaptado de (CAS, 2016). 39

Figura 6 - Composição típica de um desinfetante

Figura 7 - Efeitos respiratórios causados por agentes de limpeza (WORKPLACE SAFETY \& PREVENTION SERVICES; OCCUPATIONAL HEALTH CLINICS FOR ONTARIO WORKERS, 2010) 


\section{LISTA DE QUADROS}

Quadro 1 - Pictogramas usados entre os diferentes países para comunicar um mesmo perigo antes da harmonização pelo GHS. (quadro criado pela autora)

Quadro 2- - Perigos abrangidos pelo GHS com suas respectivas categorias (UNITED NATIONS, 2015) .30

Quadro 3 - Tipos de produtos saneantes (ANVISA, 2005)

Quadro 4 - Composição básica de um produto de limpeza. FONTE : Adaptado de (WOLKOFF et al., 1998)

Quadro 5 - Substâncias utilizadas em grande escala para produção de saneantes e seu potencial de causar efeitos prejudiciais ao meio ambiente (FEIJTEL;

PLASSCHE, 1995)

Quadro 6 - Substâncias usadas na composição de saneantes e os potenciais perigos à saúde. Adaptado de (CORRÊA, 2005) 


\section{LISTA DE FLUXOGRAMAS}

Fluxograma 1 - Perigos físicos que podem ser aplicados para saneantes . .57

Fluxograma 2 - Decisão lógica para classificação de Líquidos Inflamáveis . .59

Fluxograma 3 - Decisão lógica para classificação de Líquidos Oxidantes 61

Fluxograma 4 - Decisão lógica para classificação de sólidos inflamáveis .63

Fluxograma 5 - Decisão lógica para classificação de Corrosivo para os metais.....64

Fluxograma 6 - Decisão lógica para classificação de Aerossóis. .66

Fluxograma 7 - Decisão lógica para classificação de aerossóis em forma de spray67 Fluxograma 8 - Decisão lógica para classificação de aerossóis em forma de espuma

Fluxograma 9 - Decisão lógica para classificação de toxicidade aguda oral em saneantes líquidos

Fluxograma 10 - Decisão lógica para classificação de toxicidade aguda oral em saneantes sólidos.

Fluxograma 11 - Decisão lógica para classificação de toxicidade aguda dérmica...74 Fluxograma 12 - Decisão lógica para classificação de toxicidade aguda inalatória para produto que liberam névoas e poeiras .76

Fluxograma 13 - Decisão lógica para classificação de toxicidade aguda inalatória para produto que liberam vapores.

Fluxograma 14 - Decisão lógica para classificação de toxicidade aguda inalatória para produto que liberam gases 78

Fluxograma 15 - Decisão lógica para classificação corrosão/irritação a pele. 83

Fluxograma 16 - Decisão lógica para classificação de lesões oculares graves/irritação ocular .88

Fluxograma 17 - Decisão lógica para classificação de sensibilização à pele .92

Fluxograma 18 - Decisão lógica para classificação de sensibilização respiratória ..96 Fluxograma 19 - Decisão lógica para classificação de mutagenicidade em células germinativas. 100

Fluxograma 20 - Decisão lógica para classificação de carcinogenicidade 103

Fluxograma 21 - Decisão lógica para classificação de toxicidade à reprodução ...107 Fluxograma 22 - Decisão lógica para classificação de toxicidade para órgãos-alvo específicos - exposição única 
Fluxograma 23 - Decisão lógica para classificação de toxicidade para órgãos-alvo

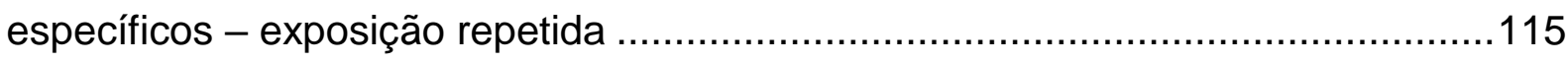

Fluxograma 24 - Decisão lógica para classificação de perigo por aspiração .........119

Fluxograma 25 - Decisão lógica para classificação de perigoso para o meio ambiente aquático - agudo

Fluxograma 26 - Decisão lógica para classificação de perigoso para o meio ambiente aquático - crônico 122 


\section{LISTA DE ABREVIATURAS E SIGLAS}

Abipla Associação Brasileira das Indústrias de Produtos de Limpeza e Afins

ABNT Associação Brasileira de Normas Técnicas

ANSI

Instituto Americano de Normas (American National Standards Institute)

Anvisa

Agência Nacional de Vigilância Sanitária

$\mathrm{BCF}$

Fator de Bioconcentração

CAS

Serviço de Resumo de Produtos Químicos (Chemical Abstract Service)

CCCR Produtos Químicos de Consumo e Regulamentações de Conteiners (Consumer Chemicals and Containers Regulations)

CE50 Concentração Efetiva Média

CEr50 Concentração média efetiva em termos de redução da taxa de crescimento

$\mathrm{Ci} \quad$ Concentração dos Ingredientes

CL50 Concentração Letal Média

CLP Classificação, rotulagem e embalagem (Classification Labelling and Packaging)

DL50 Dose Letal Média

DSD/DPS Diretiva de Substâncias Perigosas/ Diretiva de Produtos Perigosos (Dangerous Substances Directive/ Dangerous Products Directive)

ECHA Agência Européia de Produtos Químicos (European Chemicals Agency)

EPI Equipamento de Proteção Individual

ESIS Sistema Europeu de Informações de Substâncias Químicas (European Chemical Substances Information System)

ETAi Estimativa de Toxicidade Aguda do Ingrediente

ETAm Estimativa de Toxicidade Aguda da Mistura

EUA Estados Unidos da América

FDS Ficha com Dados de Segurança

FISPQ Ficha de Informações de Segurança de Produtos Químicos

GESTIS Base de Dados Alemã de Substâncias Químicas (German Databases on Hazardous Susbtance)

GHS Sistema Globalmente Harmonizado de Classificação e Rotulagem de Produtos Químicos (Globally Harmonized System of Classification and Labelling of Chemicals) 
IFA Instituto de Saúde e Segurança Ocupacional do Seguro de Acidentes Sociais da Alemanha (Institute for Occupational Safety and Health of the German Social Accident Insurance)

INCHEM Programa Internacional de Produtos Químicos (International Programme on Chemical)

INRS Instituto Nacional de Pesquisa e Segurança da França (Institut national de recherche et de sécurité)

MSDS Ficha de Dados de Segurança de Produtos (Material Safety Data Sheet)

MTE Ministério do Trabalho e Emprego

NBR Norma Brasileira

NR Norma Regulamentadora

NVZ Associação Holandesa de Sabão (Nederlandse Vereniging van Ziekenhuizen)

OIT Organização Internacional do Trabalho

ONU Organização das Nações Unidas

PE Ponto de Ebulição

PF Ponto de Fulgor

Ppmv Partes por milhão por volume

RDC Resolução da Diretoria Colegiada

SDS Ficha de Dados de Segurança (Safety Data Sheet)

SINITOX Sistema Nacional de Informações Tóxico-Farmacológicas

STOT Toxicidade sistêmica para órgãos-alvo específicos (Specific Target Organ Toxicity-STOT)

TOXNET Rede de dados Toxicológicos (Toxicology Data Network)

USEPA Agência de Proteção ao Meio Ambiente dos Estados Unidos (US Enviromental Protection Agency)

WHMIS Sistema de Informação de Produtos Perigosos no Ambiente de Trabalho do Canadá (Workplace Hazardous Materials Information System) 


\section{SUMÁRIO}

1. INTRODUÇÃO

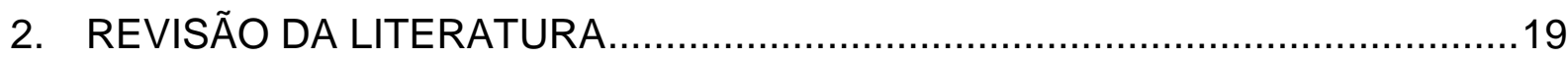

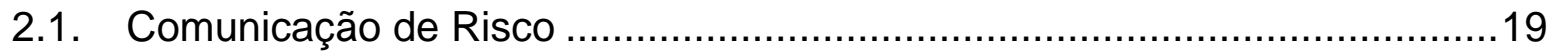

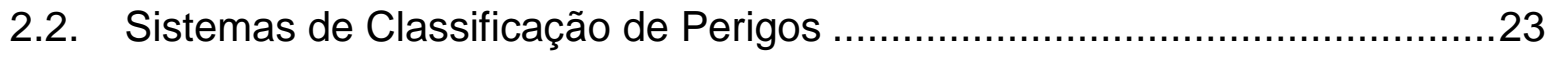

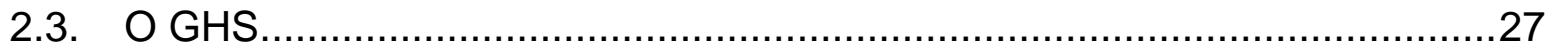

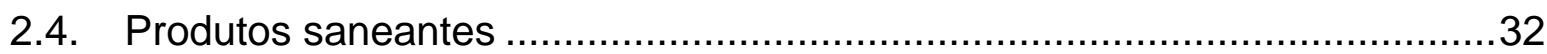

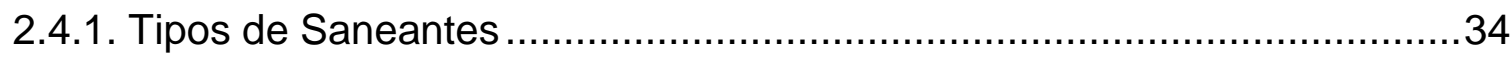

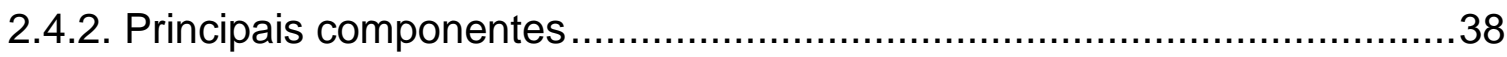

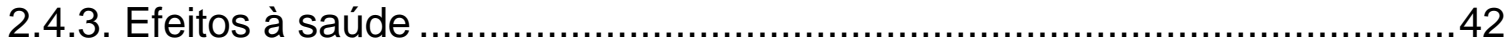

3. OBJETIVOS

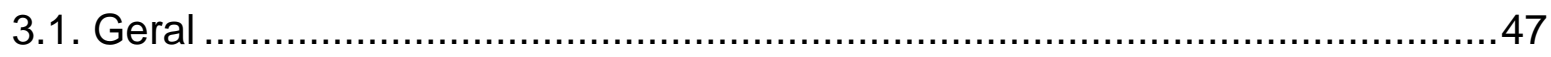

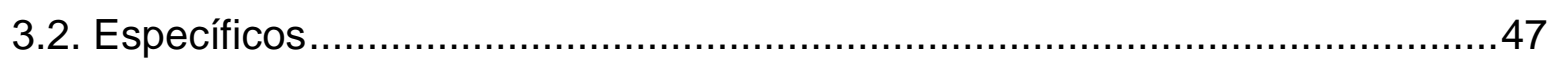

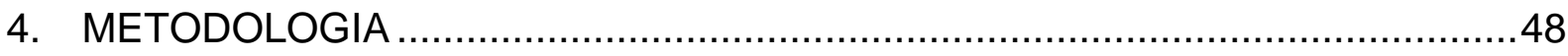

4.1. Elementos para elaboração do Roteiro ……….....................................49

5. ROTEIRO PARA APLICAÇÃO DO GHS PARA PRODUTOS SANEANTES......52

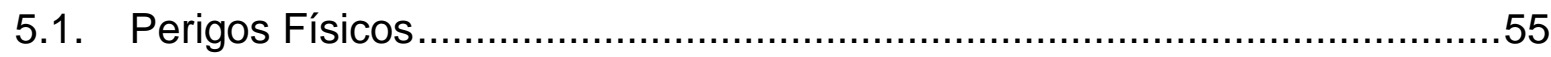

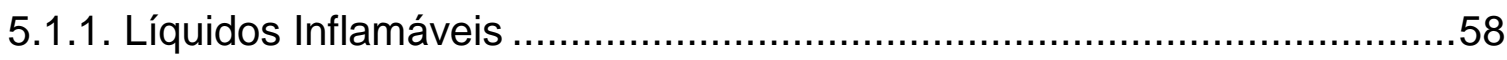

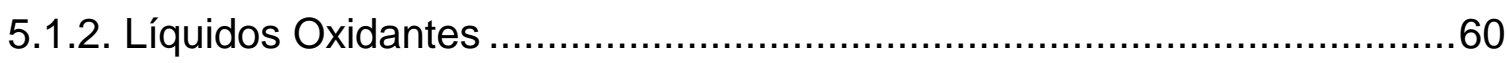

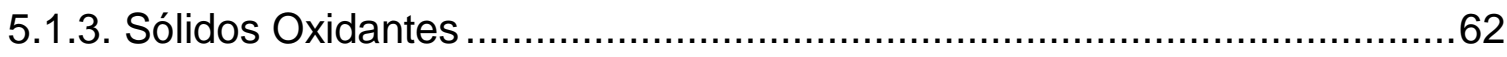

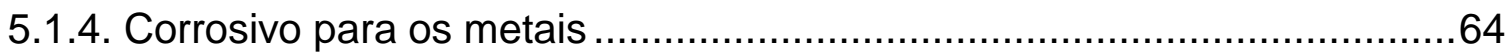

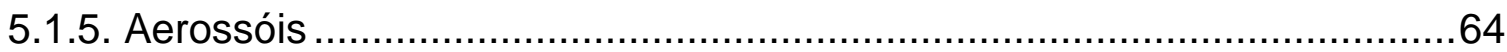

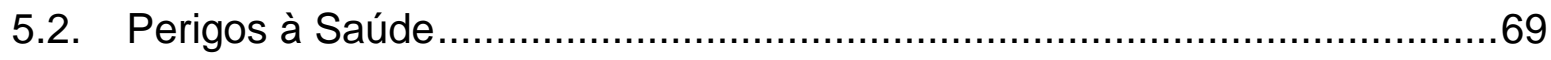

5.2.1. Toxicidade Aguda (Oral, Dérmica e Inalatória) …...................................69

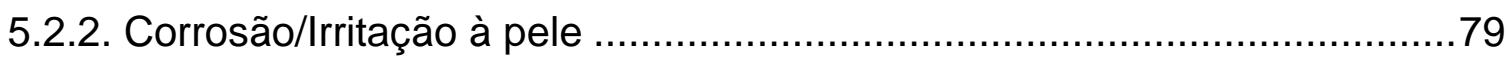

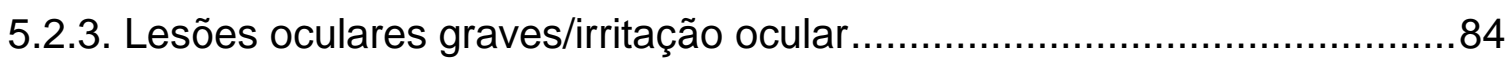

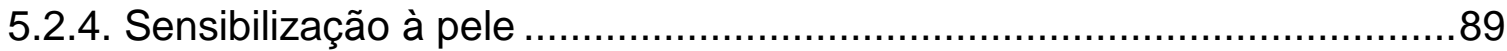

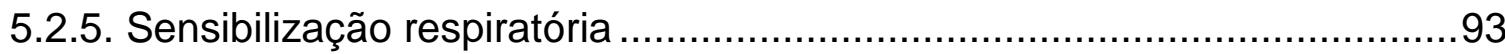

5.2.6. Mutagenicidade em Células germinativas, Carcinogenicidade e Toxicidade

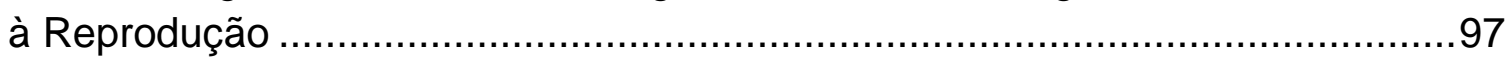

5.2.7 Toxicidade para órgãos-alvo específicos - Exposição única....................108

5.2.8 Toxicidade para órgãos-alvo específicos - Exposição repetida ...............112

5.2.9 Perigo por aspiração............................................................................116 


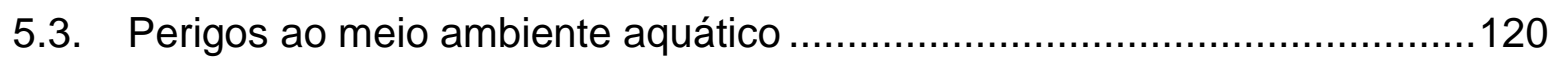

5.3.1. Perigoso para o meio ambiente aquático - Agudo ..............................120

5.3.2. Perigoso para o meio ambiente aquático - Crônico ……………...........122

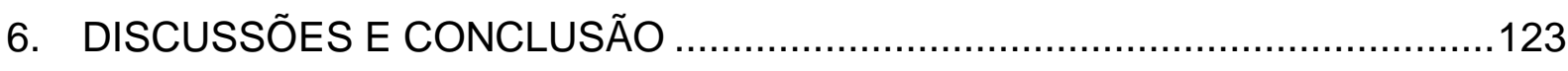

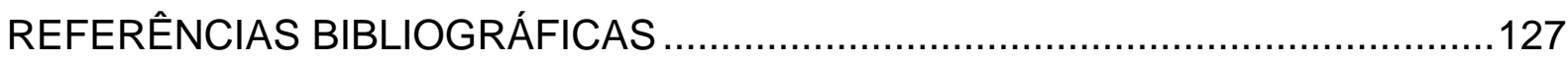

ANEXO I - Exemplo de Aplicação do Roteiro ....................................................132 


\section{INTRODUÇÃO}

Nos dias atuais, um grande número de produtos químicos é usado por diferentes indústrias ao redor do mundo (CHANG et al., 2013). Com o aumento gradativo da tecnologia, do desenvolvimento industrial e da necessidade de consumo humana, não se pode imaginar a vida sem o uso de químicos. A cada dia são desenvolvidos novos processos industriais, novos produtos e novas substâncias.

Juntamente com os benefícios dessa constante modernização, surgem as preocupações relacionadas com o uso excessivo de produtos químicos e possíveis efeitos adversos à saúde humana e meio ambiente. Segundo Wallau e Júnior (2013), nos anos 1960 as legislações para regulamentar o uso de produtos químicos perigosos se restringiram aos agrotóxicos e, somente a partir de 1998 atingiram os produtos químicos em geral.

Sabe-se que grande parte dos produtos químicos possui um potencial de causar efeitos adversos à saúde humana e ao meio ambiente e, por isso, um passo fundamental para o uso seguro de produtos químicos passou a ser a comunicação dos riscos advindos desses produtos. A identificação dos perigos é o passo principal para se fazer a comunicação de riscos. Essa e outras informações são apresentadas por meio de Fichas de Segurança e de Rótulos que devem acompanhar o produto dentro do ambiente de trabalho.

Para a identificação dos perigos, primeiro se fazia necessário o desenvolvimento de critérios para classificação de produtos e, em seguida, de uma legislação que inserisse o sistema de classificação de perigo dos produtos químicos, assim sendo cada país desenvolveu e colocou em prática a sua própria legislação (CHANG et al., 2013).

As leis ou regulamentações criadas em cada país eram similares em muitos aspectos, mas suas diferenças eram significantes o bastante para resultarem em diferentes classificações para o mesmo produto químico. Por causa de variações nos critérios de classificação, um produto químico poderia ser considerado inflamável em um país e não inflamável em outro país. Ou, poderia ser considerado cancerígeno em um país, mas não em outro (UNITED NATIONS, 2015). Isso se transformou em um 
grande problema se tratando, principalmente de importação e exportação de produtos entre países; enquanto o mercado global se intensificava, os sistemas de classificação se tornavam inconsistentes entre si (CHANG et al., 2013).

O reconhecimento desse problema levou à um desejo gradativo de uma harmonização mundial de classificação de perigo pelas autoridades responsáveis por controlar as leis de produtos químicos (MORITA; MORIKAWA, 2011). Integrar dados e unificar sistemas de classificação e rotulagem de produtos químicos pareceu ser um importante objetivo para comunidades e associações internacionais, já que isso poderia tanto eliminar substancialmente os perigos ao meio ambiente e à saúde quanto reduzir efetivamente os erros cometidos pelos mercados globais (CHANG et al., 2013).

A partir do pressuposto, a ONU criou, em 2003, o GHS, um sistema globalmente harmonizado de classificação e rotulagem de produtos químicos. Essa iniciativa consiste em trazer critérios harmonizados de classificação para perigos físicos, perigos à saúde e perigos ao meio ambiente, bem como frases e símbolos harmonizados para a comunicação desses perigos (CLARK et al., 2013).

O sistema do GHS possui em sua totalidade 30 classes de perigo e, para cada uma delas, há categorias diferentes, considerando a sua severidade. Ainda que o GHS tenha sido criado com o intuito de facilitar a comunicação de perigos, a sua aplicação não é tão simples. A identificação dos perígos e a alocação na classe e categoria corretas ainda são uma tarefa muito difícil para as empresas, com destaque para aquelas de menor porte, como é o exemplo do setor de saneantes.

De acordo com a Abipla, 95\% do setor de Saneantes é composto por micro e pequenas empresas e com um elevado ingresso de novos empreendedores a cada ano, pois não há barreiras de entrada, uma vez que o investimento de capital é baixo, não é necessária tecnologia de ponta e não se requer conhecimento técnico especializado (ABIPLA, 2013).

Só nos últimos 10 anos, 1239 empresas de saneantes obtiveram autorização de funcionamento (ABIPLA, 2015). Porém, o maior problema está na informalidade, que é muito grande no setor, resultado da falta de conhecimento das pessoas sobre as providências necessárias à abertura de uma empresa, como regras, documentações, 
alvarás e impostos (ABIPLA, 2013) e a obrigação de registros e/ou notificações dos produtos saneantes junto à Anvisa.

Como a obrigatoridade da comunicação dos riscos cabe ao fabricante e/ou fornecedor do produto e as indústrias de saneantes são, em sua maioria, micro e pequenas empresas, esse é um dos setores mais afetados na aplicação dos critérios do GHS, pelo fato de faltarem profissionais especializados nesse tipo de serviço dentro do setor. Além de terem a obrigação de seguir os requisitos estabelecidos pelo GHS, os fabricantes de saneantes são regulamentados também pela Anvisa, que instaura suas próprias normas e resoluções a serem aplicadas. Combinando os requisitos da Anvisa com os do GHS, percebe-se que algumas classes e categorias de perigo do GHS não se aplicam para esse setor, como é o caso, por exemplo, da Toxicidade Aguda. Os critérios estabelecidos pela Anvisa para comercialização de um produto saneante, não permitem que esse produto seja classificado como Toxicidade Aguda Oral - Categoria 1, 2 nem 3, apesar de, no GHS, essa classe de perigo se estender até a Categoria 5

O gerenciamento de produtos perigosos é essencial para garantir a segurança e a saúde dos trabalhadores e assegurar a proteção do meio ambiente, bem como para evitar acidentes industriais. Portanto, com esse trabalho, pretende-se estabelecer critérios para elaboração de um roteiro de aplicação do GHS voltado para o setor de saneantes, explicando o que se aplica e quais são as especificidades do setor. O objetivo desse roteiro é contribuir para que esse ramo de indústrias apresente uma correta comunicação de riscos e um gerenciamento seguro de produtos químicos. Pretende-se, com esse roteiro, otimizar a comunicação de riscos e perigos, assegurar o manuseio correto do produto durante a fabricação e a proteção dos funcionários, garantindo, assim, uma maior segurança no ambiente de trabalho. 


\section{REVISÃO DA LITERATURA \\ 2.1. Comunicação de Risco}

Embora os perigos relacionados com as subtâncias químicas já fossem conhecidos desde o século XIX, nessa época eram considerados como o 'mal necessário' para o progresso econômico e científico. Com o passar do tempo, após o aparecimento de acidentes de trabalho, contaminações ambientais e evidentes danos à saúde humana, surgiu a preocupação em comunicar esses riscos aos trabalhadores e regulamentar o uso de produtos químicos perigosos (WALLAU; JÚNIOR, 2013).

"Risco" e "Perigo" são conceitos diferentes que precisam ser entendidos antes da introdução ao tema da comunicação de risco. Perigo é a característica intrínseca ao produto de provocar algum dano, enquanto risco é a probabilidade de ocorrência de um dano causado por um produto perigoso. O perigo sempre existe, mas o risco pode ser minimizado dependendo das medidas de proteção utilizadas (UNITED NATIONS, 2015).

O termo Comunicação de Risco apareceu pela primeira vez no ano de 1984 e, desde então, se tornou um tema de debate (RODRIGUES, 2010). O público-alvo, para a comunicação de risco, deve ser tanto os trabalhadores quanto os consumidores dos produtos químicos. Empregados e trabalhadores precisam saber os perigos específicos dos químicos usados e/ou manuseados no ambiente de trabalho; bem como as informações sobre as medidas de proteção requeridas para evitar qualquer efeito adverso que possa ser causado por tais perigos. Já para o consumidor final do produto, o rótulo, muitas vezes é a única fonte informação prontamene disponível para aquele produto. Portanto, o rótulo deve ser suficientemente detalhado e conter informações relevantes ao produto. Para a comunicação de risco funcionar bem, devese haver um bom gerenciamento quanto ao uso seguro dos produtos químicos, levando em conta diferentes etapas do processo (UNITED NATIONS, 2015).

O gerenciamento do uso seguro de produtos químicos no ambiente de trabalho pode ser entedido por meio de uma pirâmide, representada na Figura 1. Na sua base está a classificação de perigos de acordo com um sistema de classificação, nesse caso, o GHS. A identificação dos perigos de um produto é o passo principal para o restante das ações. Os perigos são comunicados ao trabalhador através de documentos como a Ficha de Segurança (FDS), também conhecida como FISPQ 
(Ficha de Informações de Segurança de Produtos Químicos) e os rótulos. Esse documento, juntamente com os rótulos são, para muitos trabalhadores, a única fonte de informação disponível para o produto que estão usando (SULEIMAN; SVENDSEN, 2014) justificando, assim, sua importância.

Um documento bem elaborado deve conter informações sobre maneiras de minimizar os riscos potenciais desse produto, tais como os EPI's que devem ser usados, as medidas de engenharia que devem ser aplicadas no ambiente em que o produto é manuseado, e o monitoramento da exposição através dos limites de exposição ocupacional e dos cenários de exposição. Portanto, através desses documentos, as empresas comunicam os riscos do produto aos seus trabalhadores e constroem sistemas para gerenciamento desses riscos. Com a pirâmide bem estruturada é possível chegar, então, no uso seguro dos produtos químicos, garantindo assim a segurança dos trabalhadores.

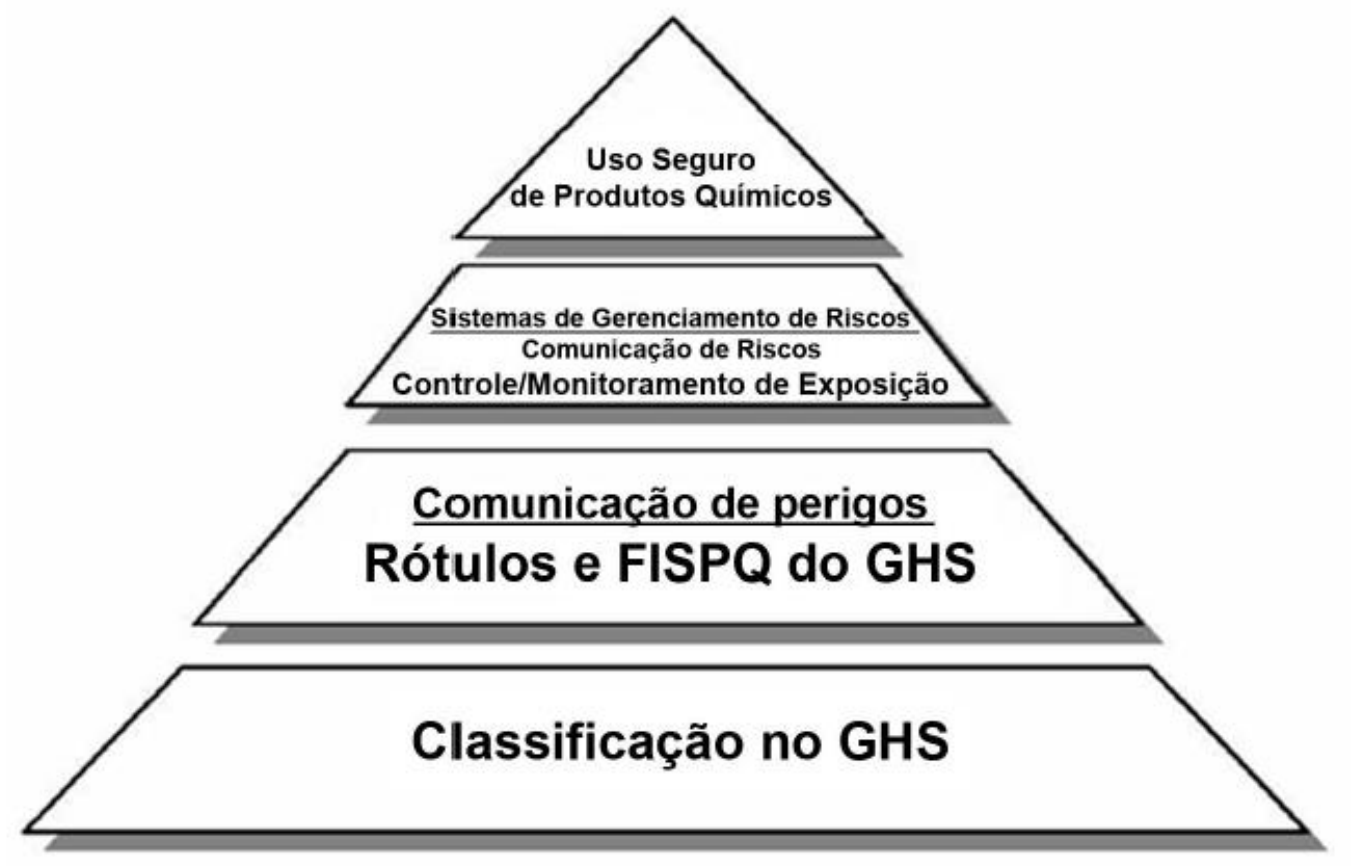

Figura 1 - Elementos de classificação e comunicação do GHS. Adaptado de ABNT 2005, (MATTA, 2011)

No Brasil, de acordo com o Decreto nํ2 2657, de 1998, que Promulga a Convenção no 170 da OIT, relativa à Segurança na Utilização de Produtos Químicos no Trabalho, assinada em Genebra, em 25 de junho de 1990, o acesso à informação acerca dos produtos químicos utilizados no local de trabalho é um direito dos trabalhadores. 
'Artigo 7

ROTULAÇÃO E MARCAÇÃO

1. Todos os produtos químicos deverão portar uma marca que permita a sua identificação.

2. Os produtos químicos perigosos deverão portar, ainda, uma etiqueta facilmente compreensível para os trabalhadores, que facilite informações essenciais sobre a sua classificação, os perigos que oferecem e as precauções de segurança que devam ser observadas".

mesmo decreto, em seu Art. 8ํㅜ, considera:

"Artigo 8

FICHAS COM DADOS DE SEGURANÇA

1. Os empregadores que utilizem produtos químicos perigosos deverão receber fichas com dados de segurança que contenham informações essenciais detalhadas sobre a sua identificação, seu fornecedor, a sua classificação, a sua periculosidade, as medidas de precaução e os procedimentos de emergência.

2. Os critérios para a elaboração das fichas com dados de segurança deverão ser estabelecidos pela autoridade competente ou por um organismo aprovado ou reconhecido pela autoridade competente, em conformidade com as normas nacionais ou internacionais.

3. A denominação química ou comum utilizada para identificar o produto químico na ficha com dados de segurança deverá ser a mesma que aparece na etiqueta”.

(BRASIL, 1998)

As fichas de segurança são usadas para comunicar informações referentes ao meio ambiente, à saúde e aos perigos de um produto químico. Contam com informações para manuseio seguro, armazenamento e disposições de substâncias puras e misturas através da cadeia de suprimentos de produtos químicos entre os mercados globais (NAYAR et al., 2015). A FISPQ ou FDS é chamada em inglês de Safety Data Sheet (SDS) ou Material Safety Data Sheet (MSDS) (ABNT, 2014).

O Decreto $\mathrm{n}^{\circ} 2657$, estabeleceu algumas responsabilidades a serem cumpridas pela ABNT NBR 14725:

a necessidade de fornecer informações sobre substâncias ou misturas perigosas relativas à segurança, à saúde e ao meio ambiente; 
$\checkmark \quad$ o direito do público-alvo de conhecer e de identificar as substâncias ou misturas perigosas que utilizam e os perigos que elas oferecem;

$\checkmark$ a utilização de um sistema simples de identificação, de fácil entendimento e aplicação, nos diferentes locais onde as substâncias ou misturas perigosas são utilizadas;

$\checkmark$ a necessidade de compatibilização desse sistema com o critério de classificação para todos os perigos previssos pelo GHS;

$\checkmark$ a necessidade de facilitar acordos internacionais e de proteger o segredo industrial e as informações confidenciais;

$\checkmark$ a capacitação e o treinamento dos trabalhadores; e

$\checkmark$ a educação e a conscientização dos consumidores.

A ficha com dados de segurança é composta por um total de 16 seções que englobam informações de diversas áreas de gerenciamento de um produto. São elas:

1 - Identificação do produto e da empresa

2 - Identificação de perigos

3 - Composição e informações sobre os ingredientes

4 - Medidas de primeiros-socorros

5 - Medidas de combate a incêndio

6 - Medidas de controle para derramamento ou vazamento

7 - Manuseio e armazenamento

8 - Controle de exposição e proteção individual

9 - Propriedades físicas e químicas

10 - Estabilidade e reatividade

11 - Informações toxicológicas

12 - Informações ecológicas

13 - Considerações sobre destinação final 
14 - Informações sobre transporte

15 - Informações sobre regulamentações

16 - Outras informações

O conteúdo das fichas nem sempre é confiável. Conforme destacado por (WILLEY, 2012), muitas vezes as FDS são preparadas com o objetivo de estarem em conformidade com a legislação, enquanto os requisitos de informar e proteger a saúde humana e o meio ambiente são deixados de lado. A falta de qualidade das fichas pode surgir quando uma FDS não fornece detalhes suficientes em relação aos perigos das substâncias e misturas e das medidas de proteção adequadas que devem ser tomadas para utilizar um produto de forma segura. Variações nos conteúdos das fichas podem ser resultado da falta de informações disponíveis, da competência e conhecimento da pessoa que está elaborando o documento e da falta de comunicação com a cadeia de fornecedores (NAYAR et al., 2015).

Devido ao setor de saneantes ser, em sua maioria, composto por pequenas e médias empresas, dificilmente encontram-se profissionais especializados na classificação de produtos e elaboração de documentos de segurança que farão uma análise completa das informações a serem inseridas nas fichas e nos rótulos ${ }^{1}$.

\subsection{Sistemas de Classificação de Perigos}

A partir da premissa de que os riscos dos produtos deveriam ser comunicados, cada país desenvolveu e/ou adotou um sistema de classificação. Alguns países adotaram sistemas já existentes e outros criaram sistemas novos. Porém, pela falta de harmonização, havia grande divergência na forma classificar e de comunicar os perigos.

Comparando-se alguns sistemas de classificação, é possível ver a complexidade de atender a todos os regulamentos locais e globais. Além da diversidade de

\footnotetext{
${ }^{1}$ No Brasil ainda faltam profissionais especializados na busca e análise de informações de substâncias para a correta classificação de acordo com o GHS, fazendo com que grande parte das industrias contratem empresas especializadas de consultoria para realizarem esse serviço ou peguem uma classificação de produto similar disponível na internet e copiem para seu produto.
} 
pictogramas existentes, os critérios de classificação para cada classe de perigo eram diferentes de um sistema para outro.

A toxicidade aguda oral é um bom exemplo para exemplificar essa diferença. Apesar de a maioria dos sistemas existentes definirem e incluirem em sua lista de perigos a Toxicidade Aguda, os critérios para classificação variavam consideravelmente de país para país, dependendo do sistema de classificação adotado em cada um deles. Essas diferenças faziam com que o mesmo produto fosse considerado perigoso em um país ou por um sistema, mas não em outro.

Por exemplo, uma substância com uma DL50² Oral de 257 mg/kg nos EUA, Canadá, Japão e Coréia do Sul, era considerada como sendo uma substância tóxica. Já na União Européia, Austrália, Malásia e Tailândia, essa mesma substância era classificada como nociva. Seguindo os critérios de classificação da Índia, essa era uma substância não-tóxica. E, para a China, essa era uma substância não perigosa. Observou-se então que havia entre os países uma disparidade tanto dos nomes das classes de perigos quanto entre critérios estabelecidos para classificação em cada um deles.

$$
\mathrm{DL} 50=257,0 \mathrm{mg} / \mathrm{kg}
$$

\footnotetext{
${ }^{2}$ DL50 : Dose Letal que afeta $50 \%$ da população estudada. É medida em $\mathrm{mg} / \mathrm{L}$ de peso corpóreo. Os estudos de toxicidade aguda destinados a avaliar os efeitos sistêmicos letais, expressam o grau de toxicidade de uma substância com base no valor da DL50 (dose letal média) e/ou da CL50 (concentração letal média), as quais determinam a dose média (oral e dérmica) ou concentração média administrada (por inalação) da substância que produz o óbito em $50 \%$ dos animais testados.
} 


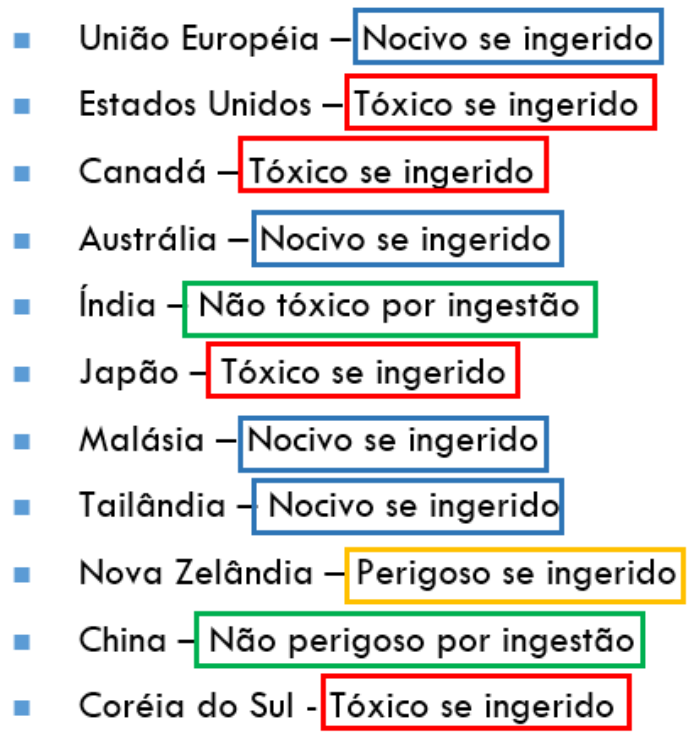

Figura 2 Comparação entre a classificação de toxicidade para um produto com uma DL50 de $257,0 \mathrm{mg} / \mathrm{kg}$ entre os países usando seus sistemas de classificação antes da harmonização pelo GHS. Adaptado de (MERCOSUL, 2013) .

Além da diferença entre os critérios de classificação, os pictogramas, ou símbolos usados para comunicar um perigo, eram diferentes. A tabela abaixo compara pictogramas para duas diferentes classes de perigo, tóxico e inflamável, entre 6 diferentes sistemas de classificação.

\begin{tabular}{|l|l|l|}
\hline Sistema de Classificação & Tóxico & Corrosivo \\
\hline WHMIS (Canadá) & & \\
\hline CCCR (Canadá) &
\end{tabular}




DSD/DPD (Europa)

Quadro 1 - Pictogramas usados entre os diferentes países para comunicar um mesmo perigo antes da harmonização pelo GHS. (quadro criado pela autora)

É notável, então, que a comunicação de perigo de um produto variava bastante ao redor do mundo. As empresas que desejassem importar e/ou exportar produtos deveriam ter funcionários totalmente especializados capazes de elaborar rótulos e fichas de segurança de acordo com as regulamentações de cada país ou região. Além disso, dada a complexidade do desenvolvimento e manutenção de um sistema de classificação e rotulagem de produtos químicos compreensível e eficiente, muitos países ainda não possuiam o seu próprio sistema de classificação (UNITED NATIONS, 2015), assim como, muitos ainda não o possuem. 


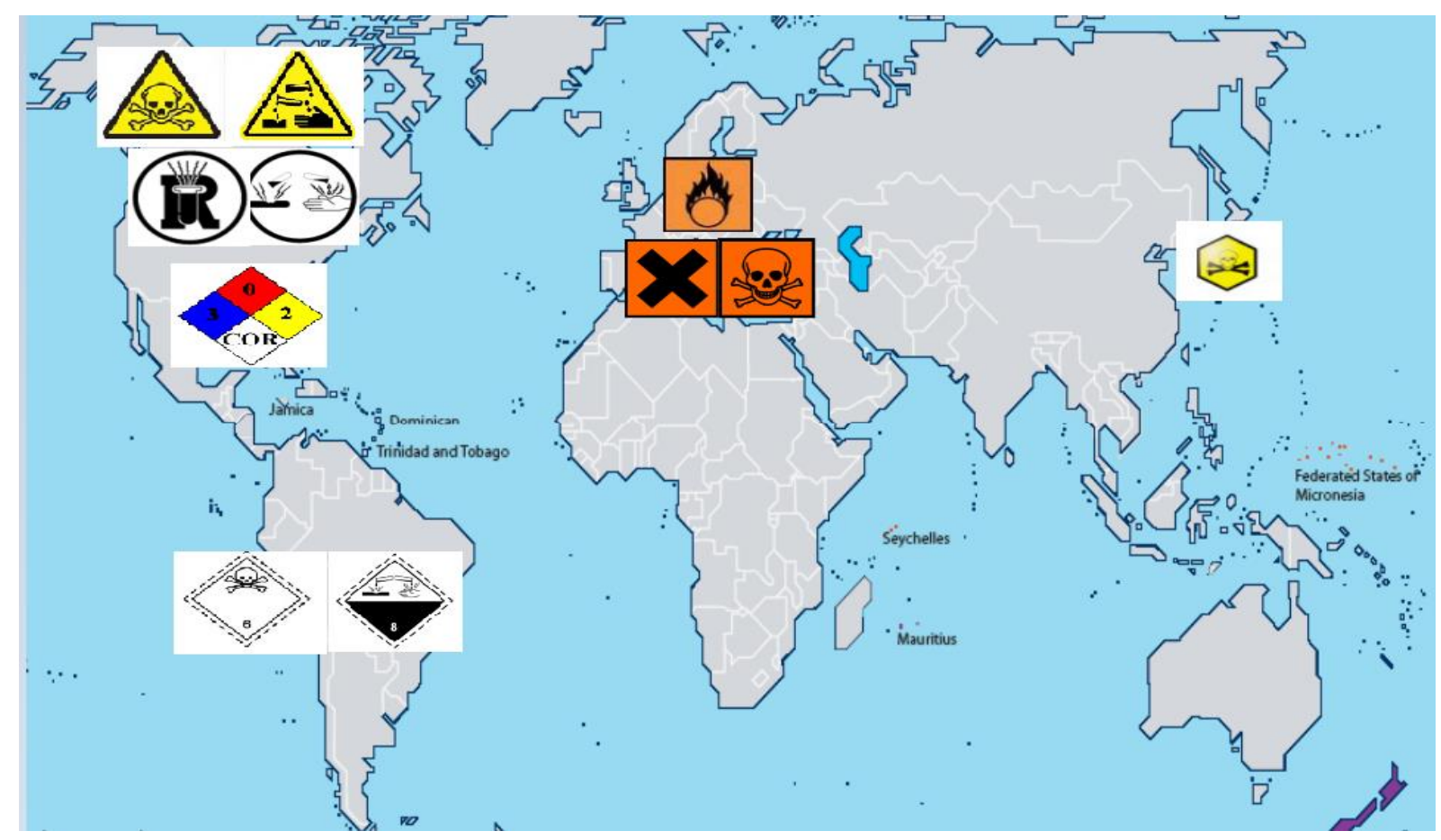

Figura 3 Diferentes pictogramas presentes no rótulo de um mesmo produto antes da harmonização pelo GHS. Adaptado de (MERCOSUL, 2013; PUIATTI, 2011)

Foi então que a ONU, após diversas constatações de que um sistema harmonizado entre os países seria exremamente útil, recomendou e publicou o GHS que visa reforçar a proteção à saúde e ao meio ambiente fornecendo um sistema internacionalmente compreensível para a comunicação de perigo (MORITA; MORIKAWA, 2011).

\subsection{O GHS}

O GHS - Sistema Globalmente Harmonizado de Classificação e Rotulagem de Produtos Químicos, também conhecido como Purple Book, foi resultado da Conferência das Nações Unidas sobre Meio Ambiente e Desenvolvimento Sustentável realizada em 1992 na cidade do Rio de Janeiro, a Eco 923 ${ }^{3}$ (ABNT, 2010).

\footnotetext{
${ }^{3}$ Eco 92, Conferência das Nações Unidas sobre o Meio Ambiente e o Desenvolvimento, foi uma conferência de chefes de estado organizada pelas Nações Unidas e realizada de 3 a 14 de junho de 1992 na cidade do Rio de Janeiro, e teve como objetivo discutir problemas ambientais. Teve como principal resultado a Agenda 21.
} 
"Até o ano de 2000 deve-se dispor, se possível, um sistema de classificação de riscos e rotulagem harmonizado mundialmente, incluindo-se fichas de segurança $e$ símbolos de fácil compreensão" (CÂMARA DOS DEPUTADOS, 1995)

O Purple Book foi inicialmente aprovado em 2002, por um comitê de peritos sobre Transporte de Produtos Perigosos das Nações Unidas e sobre o Sistema Globalmente Harmonizado de Classificação e Rotulagem de Produtos Químicos. O intuito foi fornecer um sistema harmonizado de classificação das substâncias químicas por tipos de perigos, rótulos e fichas de segurança para assegurar que as informações sobre perigos físicos e toxicidade dos produtos químicos estivessem disponíveis (ALMEIDA, 2010).

A ONU publicou então, em 2003 a primeira edição do Purple Book, e que vem sendo atualizada constantemente de dois em dois anos e, atualmente, está em sua 6ª revisão (UNITED NATIONS, 2015).

Estão, entre os objetivos do GHS, aumentar a proteção da saúde humana e do meio ambiente e facilitar o comércio internacional de produtos químicos cujos riscos sejam apropriadamente avaliados e identificados em uma base internacional (ABNT, 2010).

Uma das finalidades do GHS é identificar os perigos intrínsecos tanto de substâncias quanto de misturas. Os critérios de classificação de perigos do GHS foram harmonizados com base na análise dos principais sistemas de classificação mundiais, na avaliação de bases científicas e na discussão entre especialistas.

O GHS engloba um total de 30 classes de perigos, as quais se dividem, dependendo da sua natureza, em Perigos Físicos (16 Classes), Perigos à Saúde (11 Classes) e Perigos ao Meio Ambiente (3 Classes). Cada uma das classes de perigo possui categorias, que variam conforme a severidade do efeito. A tabela abaixo ilustra as classes de perigo com suas respectivas categorias. Quanto menor a categoria, mais severo é o dano. 


\begin{tabular}{|c|c|c|c|c|c|c|c|}
\hline \multirow{17}{*}{ 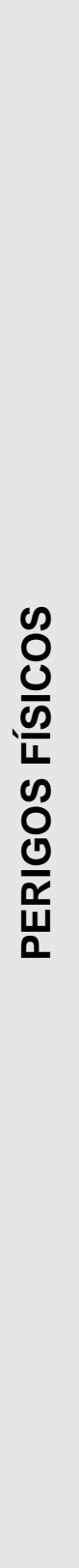 } & Classe de Perigo & \multicolumn{6}{|c|}{ Categorias } \\
\hline & Explosivos & 1.1 & 1.2 & 1.3 & 1.4 & 1.5 & 1.6 \\
\hline & Gases Inflamáveis & 1 & 2 & & & & \\
\hline & Aerossóis & 1 & 2 & 3 & & & \\
\hline & Gases Oxidantes & 1 & & & & & \\
\hline & Gases sob pressão & $\begin{array}{c}\text { Compri- } \\
\text { mido }\end{array}$ & Liquefeito & $\begin{array}{l}\text { Liquefeio } \\
\text { refrigerado }\end{array}$ & Dissolvido & & \\
\hline & Líquidos Inflamáveis & 1 & 2 & 3 & 4 & & \\
\hline & Sólidos Inflamáveis & 1 & 2 & & & & \\
\hline & $\begin{array}{l}\text { Substâncias e misturas autor- } \\
\text { reativas }\end{array}$ & $A$ & B & $\mathrm{C}$ & $\mathrm{D}$ & $E$ & $\mathrm{Fe} \mathrm{G}$ \\
\hline & Líquidos pirofóricos & 1 & & & & & \\
\hline & Sólidos pirofóricos & 1 & & & & & \\
\hline & $\begin{array}{l}\text { Substâncias e misturas sujei- } \\
\text { tas a autoaquecimento }\end{array}$ & 1 & 2 & & & & \\
\hline & $\begin{array}{l}\text { Substâncias e misturas que, } \\
\text { em contato com a água, emi- } \\
\text { tem gases inflamáveis }\end{array}$ & 1 & 2 & 3 & & & \\
\hline & Líquidos oxidantes & 1 & 2 & 3 & & & \\
\hline & Sólidos oxidantes & 1 & 2 & 3 & & & \\
\hline & Peróxidos orgânicos & $A$ & B & C & $\mathrm{D}$ & $E$ & $\mathrm{Fe} \mathrm{G}$ \\
\hline & Corrosivo para os metais & 1 & & & & & \\
\hline \multirow{7}{*}{ 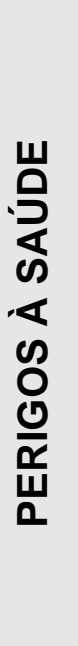 } & $\begin{array}{l}\text { Toxicidade Aguda (Oral, Dér- } \\
\text { mica e/ou Inalatória }\end{array}$ & 1 & 2 & 3 & 4 & 5 & \\
\hline & Corrosão/Irritação à pele & $\begin{array}{l}1(\mathrm{~A}, \mathrm{~B} \\
\mathrm{C})\end{array}$ & 2 & 3 & & & \\
\hline & $\begin{array}{l}\text { Lesões Oculares graves//rrita- } \\
\text { ção ocular }\end{array}$ & 1 & $2(A, B)$ & & & & \\
\hline & Sensibilização à pele & 1 & & & & & \\
\hline & Sensibilização Respiratória & $1(A, B)$ & & & & & \\
\hline & $\begin{array}{l}\text { Mutagenicidade em células } \\
\text { germinativas }\end{array}$ & $1(A, B)$ & 2 & & & & \\
\hline & Carcinogenicidade & $1(A, B)$ & 2 & & & & \\
\hline
\end{tabular}




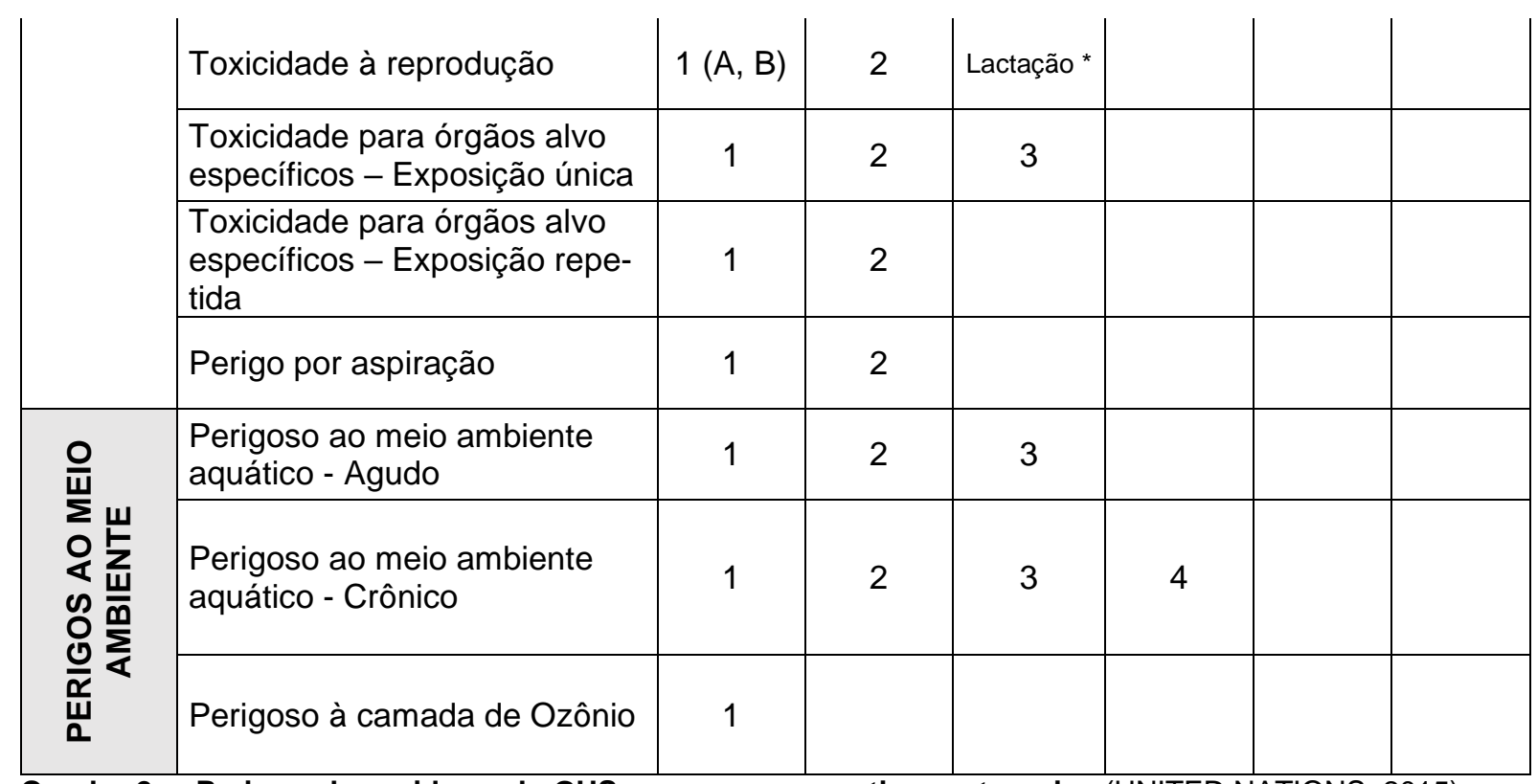

Quadro 2- - Perigos abrangidos pelo GHS com suas respectivas categorias (UNITED NATIONS, 2015)

No GHS estão contidos tanto os critérios para classificação de substâncias puras, como também os critérios para classificação de misturas. Entende-se por mistura, duas ou mais substâncias misturadas ou em solução que não reagem entre si (UNITED NATIONS, 2015).

A forma de comunicar os perigos, já classificados por um critério harmonizado ficou então, consistente. Todos os países deveriam adotar os pictogramas estabelecidos pelo GHS. 


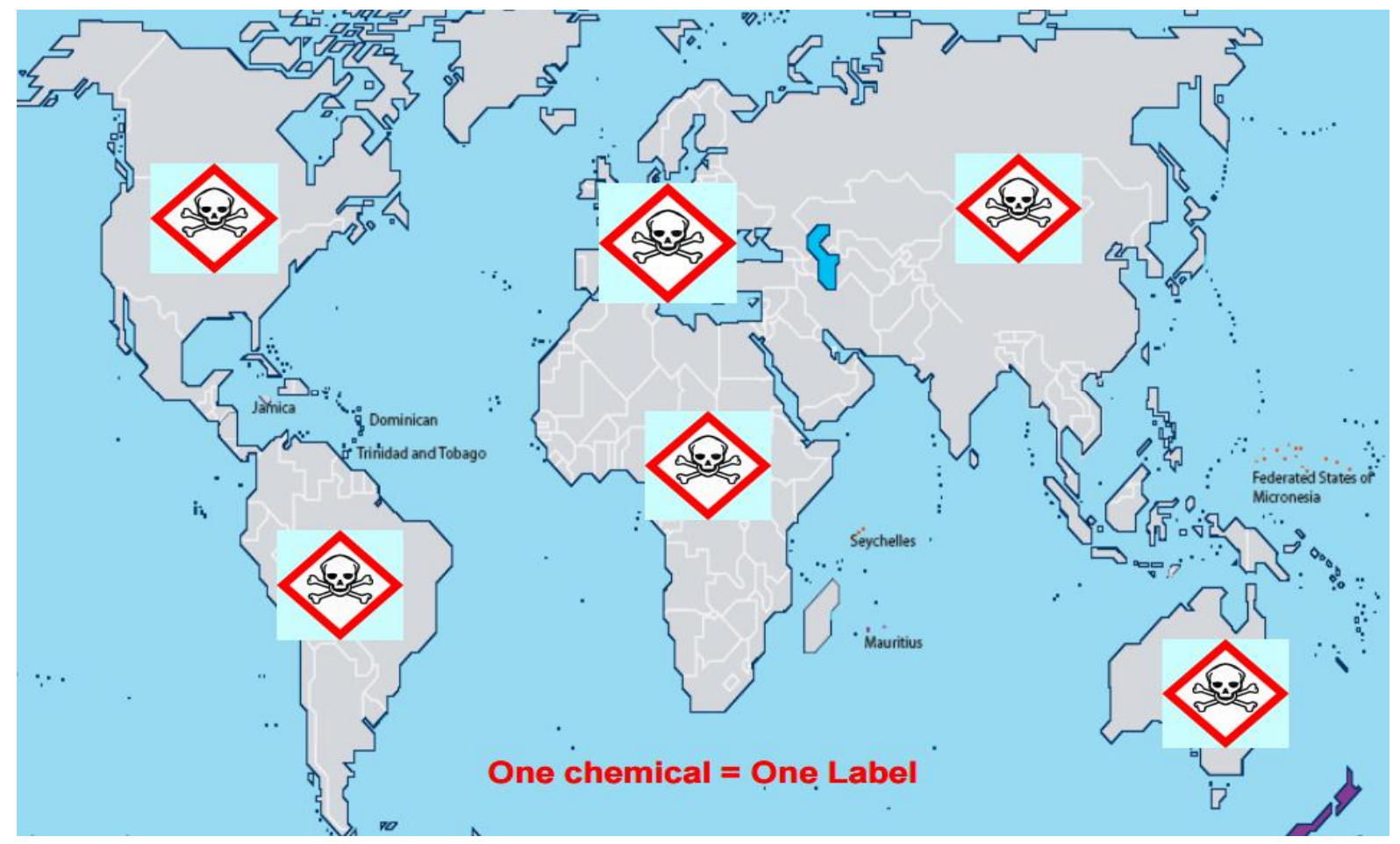

Figura 4- Pictogramas harmonizados pelo GHS (MERCOSUL, 2013; PUIATTI, 2011)

Apesar do conceito de GHS ser um "sistema globalmente harmonizado", cada país se adequou ou está se adequando a esse sistema. Por isso, as autoridades competentes de cada país ou região podem adaptar o GHS de acordo com a realidade local, decidindo quais classes de perigo serão aplicadas, priorizando algumas ou não adotando determinada categoria de perigo. Porém, para fazer essa adaptação, algumas restrições devem ser observadas para preservar a harmonização:

a) os critérios de classificação, tais como os valores de corte das categorias, deverão ser mantidos, com exceção das categorias limites que tem um tratamento especial;

b) quando se adota uma categoria para uma classe de perigo, as categorias acima desta também devem ser incluídas; e

c) quando se adota uma classe de perigo, pelo menos a categoria de maior perigo deverá ser incluída.

A classificação por perigo incorpora três etapas:

- identificação de dados relevantes sobre o perigo da substância ou mistura. 
- revisão e análise de todos esses dados para verificar os perigos da substância ou mistura.

- decisão em relação à classificação do produto ou mistura como perigosa ou não e sobre o grau de perigo de acordo aos critérios de classificação.

Por isso, por mais que haja um sistema globalmente harmonizado, ainda estão presentes diferenças nas classificações, principalmente no que diz respeio às categorias adotadas em cada país ou região.

A classificação de produtos químicos de acordo com o GHS e a elaboração dos documentos de segurança (rótulos e FDS) de acordo com a metodologia do GHS requer análise e interpretação de propriedades físico químicas e dados tóxicológicos e ecotoxicológicos das substâncias. Esse não é um processo fácil e demanda uma vários profissionais de diversas disciplinas para o fazerem, visso que abrange diferentes áreas de atuação (química, biologia, medicina, meio ambiente, farmácia, bombeiros e socorristas).

\subsection{Produtos saneantes}

Os produtos de limpeza doméstica são usados para manter a funcionalidade, aparência e as condições de higiene adequadas em nossas casas (CASAS et al., 2013). Tais produtos se tornaram parte indispensável da vida moderna e são usados diariamente na maioria dos ambientes. Uma grande variedade de novos agentes de limpeza tem sido desenvolvida para facilitar a remoção de sujeira e desinfetar superfícies (QUIRCE; BARRANCO, 2010).

De acordo com a Associação Holandesa de Produtos de Limpeza (NVZ), o consumo total de detergentes e produtos de limpeza na Holanda é de 330 mil toneladas por ano (FEIJTEL; PLASSCHE, 1995). O Brasil, em 2014, ficou em 4ㅇ lugar no ranking de crescimento mundial do setor de produtos de limpeza, atingindo um faturamento da ordem de USD 7,8 bilhões. Os EUA lideram o ranking, movimentando um total de 25,5 bilhões. Entre os EUA e o Brasil aparecem China e Japão (ABIPLA, 2015). Dentre os produtos que mais se destacaram pelo crescimento nos últimos cinco anos estão os produtos para lavagem de louças $(37,3 \%)$, produtos para limpeza de 
superfícies (25,7\%), purificadores de ar (19,5\%), produtos de cuidado com o lar $(17,3 \%)$ e, por último, os produtos de cuidado com a roupa $(15,6 \%)$ e produtos para o banheiro $(15,2 \%)$.

Porém, os saneantes, quando utilizados de forma inadequada, representam risco para a saúde, devido à alta toxidade da maioria de seus compostos (SANTOS et al., 2011). Há estudos que relatam também o potencial de efeitos tóxicos ao ambiente aquático devido à presença de ingredientes de produtos saneantes. Os tratamentos de água existentes hoje em dia não são capazes de remover completamente algumas destas substâncias que prejudicam a biota aquática (ELGAWAD, 2014).

Grande parte dos produtos saneantes leva em sua composição, ingredientes conhecidamente tóxicos, irritantes e com potencial sensibilizante à pele e ao sistema respiratório (ARIF; DELCLOS, 2012; BÉDARD et al., 2014; BERNSTEIN et al., 1994; DUMAS et al., 2014; ROSENMAN et al., 2003; VIZCAYA et al., 2013). As fragrâncias, usadas para melhorar o odor de vários produtos, contêm uma série de substâncias tóxicas em sua composição (BÉDARD et al., 2014). Por outro lado, os saneantes em forma de sprays têm grande risco por exposição inalatória, existindo evidências de que podem causar asma (BELLO et al., 2010).

Na composição de saneantes pode haver a presença de substâncias cáusticas, como por exemplo, cloreto de benzalcônio em detergentes, fenol em antissépticos, ácido oxálico em desinfetantes, ácido fórmico em desodorizantes e hipoclorito de sódio em alvejantes. As exposições tóxicas a esses produtos são comuns no Brasil e os acidentes tóxicos, especialmente os não intencionais, constituem a principal causa de atendimento de emergência pediátrica (FOOK et al., 2013).

No período de 1994 até 2003, foram notificados 694.538 casos de intoxicação humana no Brasil, sendo 291.783 casos (42\%) por produtos regulamentados pela Anvisa (medicamentos, saneantes, cosméticos, alimentos). Os medicamentos e os produtos saneantes (pesticidas domésticos, raticidas e domissanitários) são as principais causas de intoxicação, sendo que os casos não intencionais ocorrem em sua mairoria com produtos saneantes (PRESGRAVE; CAMACHO; VILLAS BOAS, 2009). Já no ano de 2013 , os produtos domissanitários foram a causa de $8,55 \%$ das intoxicações por produtos químicos registradas pelo SINITOX no Brasil, provocando 
um total de 3601 casos de intoxicação e ficando abaixo somente dos medicamentos $(28,45 \%)$ e drogas de abuso (10,29\%) (SINITOX, 2013).

O grande número de intoxicações com saneantes não significa, porém, que são mais perigosos que outros produtos químicos, mas que eles são mais frequentemente ingeridos do que outros (DICKEY, 2009-2015).

Além da intoxicação por consumidores de produtos saneantes, os trabalhadores do setor de limpeza estão entre os grupos ocupacionais com maior incidência de dermatite de contato (BAUER, 2013; CARØE; EBBEHØJ; AGNER, 2014) e têm um risco elevado de asma e rinite (FOLLETTI et al., 2014; VIZCAYA et al., 2013). Uma percepção comum entre os trabalhadores e as empresas do setor de saneantes, entretanto, é a de que produtos de limpeza são menos perigosos do que produtos químicos de outros setores (SULEIMAN; SVENDSEN, 2014).

E não é só isso, há também uma grande preocupação com a quantidade de produtos clandestinos, que estão à venda sem permissão e avaliação do Ministério da Saúde. Os saneantes clandestinos são vendidos não só por ambulantes em 'caminhões', diretamente nas residências, mas também em estabelecimentos comerciais que revendem produtos e artigos para limpeza. O comércio de saneantes clandestinos no país coloca em riscos a saúde da população, uma vez que suas formulações não possuem ingredientes próprios para a finalidade informada, ou os contêm em quantidade insuficiente ou aumentada. Trata-se de um problema para a Saúde Pública e um desafio para a Vigilância Sanitária, porque torna a população susceptível a eventos adversos e a intoxicações (SANTOS et al., 2011).

\subsubsection{Tipos de Saneantes}

De acordo com a definição da Anvisa, saneantes são substâncias ou preparações destinadas à higienização, desinfecção ou desinfestação domiciliar, em ambientes coletivos e/ou públicos, em lugares de uso comum e no tratamento de água, podendo ser separados em detergentes, alvejantes, desinfetantes, desodorizantes, esterilizantes, algicidas para piscinas, fungicidas para piscinas, 
desinfetante de água para o consumo humano, água sanitária, produtos biológicos, inseticidas, raticidas, jardinagem amadora, repelentes (SANTOS et al., 2011).

A Anvisa agrupa os produtos saneantes de acordo com seguintes conceitos:

\begin{tabular}{|c|c|}
\hline ÁGUA SANITÁRIA & $\begin{array}{l}\text { - São soluções aquosas à base de hipoclorito de sódio ou } \\
\text { cálcio, com teor de cloro ativo entre } 2,0 \text { a } 2,5 \% \text { p/p, durante } \\
\text { o prazo de validade (máximo de } 6 \text { meses). esse produto } \\
\text { pode conter apenas hidróxido de sódio ou cálcio, cloreto de } \\
\text { sódio ou cálcio e carbonato de sódio ou cálcio como } \\
\text { estabilizantes. Pode ter ação de alvejante e de desinfetante } \\
\text { de uso geral. }\end{array}$ \\
\hline $\begin{array}{l}\text { ALGICIDAS PARA } \\
\text { PISCINAS }\end{array}$ & $\begin{array}{l}\text { - São substâncias ou produtos que têm o objetivo de matar } \\
\text { algas em piscinas. }\end{array}$ \\
\hline ALVEJANTES & $\begin{array}{l}\text { - É qualquer substância com ação química, oxidante ou } \\
\text { redutora, que exerce ação branqueadora. }\end{array}$ \\
\hline $\begin{array}{c}\text { DESINFETANTE DE ÁGUA } \\
\text { PARA O CONSUMO } \\
\text { HUMANO }\end{array}$ & $\begin{array}{l}\text { - São substâncias ou produtos destinados à desinfecção de } \\
\text { água potável, própria para consumo humano. }\end{array}$ \\
\hline DESINFETANTES & $\begin{array}{l}\text { - São formulações que têm na sua composição substâncias } \\
\text { microbicidas e apresentam efeito letal para microrganismos } \\
\text { não esporulados. Podem ser usados para uso geral, em } \\
\text { indústrias alimentícias, em piscinas, em lactários, em } \\
\text { superfícies fixas ou outros artigos de hospitais. }\end{array}$ \\
\hline DESODORIZANTES & $\begin{array}{l}\text { - São formulações que têm na sua composição substâncias } \\
\text { microbioestáticas, capazes de controlar os odores } \\
\text { desagradáveis advindos do metabolismo microrgânico. Não } \\
\text { apresentam efeito letal sobre microrganismos, mas inibem o } \\
\text { seu crescimento e multiplicação. Podem ser usados para } \\
\text { desodorizar ambientes, aparelhos sanitários, entre outros. }\end{array}$ \\
\hline
\end{tabular}




\begin{tabular}{|c|c|}
\hline $\begin{array}{l}\text { DETERGENTES E SEUS } \\
\text { CONGÊNERES }\end{array}$ & $\begin{array}{l}\text { - São substâncias que apresentam como finalidade a } \\
\text { limpeza e conservação de superfícies inanimadas, como por } \\
\text { exemplo: detergentes; alvejantes; amaciante de tecidos; } \\
\text { antiferruginosos; ceras; desincrustantes ácidos e alcalinos; } \\
\text { limpa móveis, plásticos, pneus, vidros; polidores de sapato, } \\
\text { superfícies metálicas; removedores; sabões; saponáceos e } \\
\text { outros. }\end{array}$ \\
\hline ESTERILIZANTES & $\begin{array}{l}\text { - São formulações que têm na sua composição substâncias } \\
\text { microbicidas e apresentam efeito letal para microrganismos } \\
\text { esporulados e não esporulados. }\end{array}$ \\
\hline $\begin{array}{l}\text { FUNGICIDAS PARA } \\
\text { PISCINAS }\end{array}$ & $\begin{array}{l}\text { - São substâncias ou produtos destinados a matar todas as } \\
\text { formas de fungos. }\end{array}$ \\
\hline INSETICIDAS & $\begin{array}{l}\text { - São produtos desinfestantes destinados à aplicação em } \\
\text { domicílios e suas áreas comuns, no interior de instalações, } \\
\text { edifícios públicos ou coletivos e ambientes afins para } \\
\text { controle de insetos e outros animais incômodos e nocivos à } \\
\text { saúde. }\end{array}$ \\
\hline JARDINAGEM AMADORA & $\begin{array}{l}\text { - São produtos destinados à aplicação em jardins ou plantas } \\
\text { ornamentais, cultivadas sem fins lucrativos, para o controle } \\
\text { de pragas e doenças e bem como aqueles destinados a } \\
\text { revitalização e ao embelezamento das plantas. }\end{array}$ \\
\hline PRODUTOS BIOLÓGICOS & $\begin{array}{l}\text { - São produtos à base de microrganismos viáveis para o } \\
\text { tratamento de sistemas sépticos, tubulações sanitárias de } \\
\text { águas servidas, e para outros locais, com a finalidade de } \\
\text { degradar matéria orgânica e reduzir os odores. }\end{array}$ \\
\hline RATICIDAS & $\begin{array}{l}\text { - São produtos desinfestantes destinados à aplicação em } \\
\text { domicílios e suas áreas comuns, no interior de instalações, } \\
\text { edifícios públicos ou coletivos e ambientes afins para } \\
\text { controle de roedores. }\end{array}$ \\
\hline
\end{tabular}




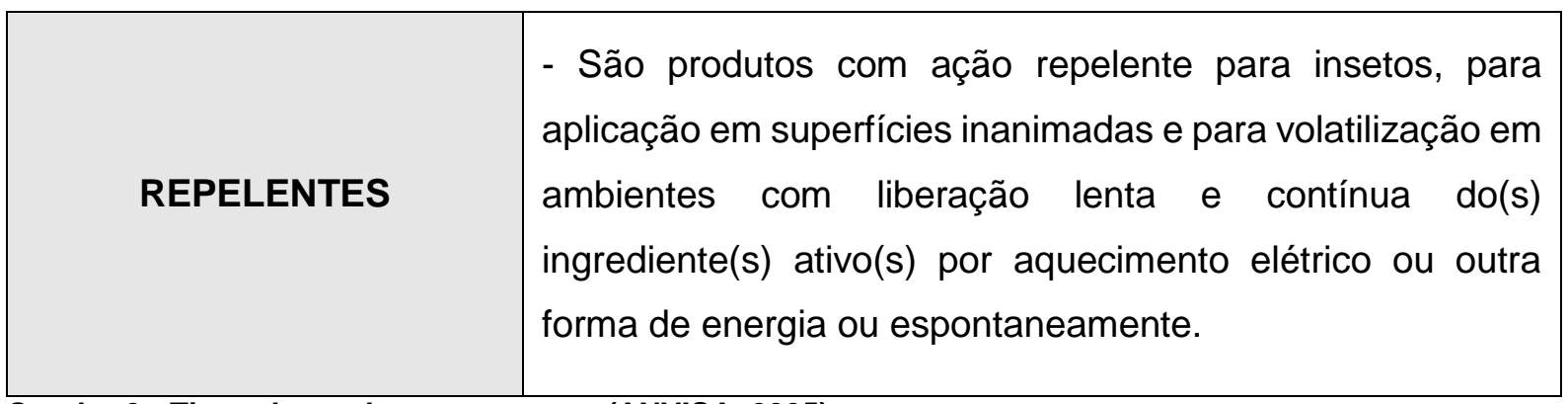

Quadro 3 - Tipos de produtos saneantes (ANVISA, 2005)

É possível encontrar saneantes nos 3 estados físicos existentes. Apesar da maioria ser líquida (desinfetante, amaciante, limpa vidro, esterilizantes, alvejantes) também são encontrados na forma sólida (ceras, sabão em pó, sabão em barra) aerossól.

Além de cenceitualizar os tipos de produtos saneantes, a Anvisa estabelece uma classificação, que deve ser seguida para a comercialização de produtos de limpeza.

No Brasil, o registro e a notificação de produtos saneantes são regulamentados pela Anvisa através da Resolução da Diretoria Colegiada nำ59, que dispoe sobre as regras estabelecidas pelo Ministério da Saúde e a Anvisa sobre embalagem, rotulagem, risco, importação e aspectos técnicos. Dentro desse regulamento, os produtos são classificados em risco I e II. Para serem comercializados, os de risco I devem atender às exigências da Anvisa e possuem um processo de regularização simplificado via notificação de produto, enquanto que os de risco II precisam de analise técnica e registro para sua liberação (ABIPLA, 2015).

Para ser classificado como Risco I, o produto não pode possuir pH extremo $(\mathrm{pH}$ $<2$ ou $\mathrm{pH}>11$,5) nem apresentar características de corrosividade, ação antimicrobiana, ação desinfestante e não ser à base de microorganismos viáveis. Também não podem conter, em sua composição, algum dos seguintes ácidos inorgânicos: fluorídrico (HF), nítrico (HNO3), sulfúrico (H2SO4); ou seus sais que os liberem nas condições de uso do produto (ANVISA, 2010).

Já os produtos de Risco II, possuem valor de $\mathrm{pH}$ extremo, características de corrosividade, ação antimicrobiana, ação desinfestante ou são à base de microorganismos viáveis. Podem conter, em sua composição, algum dos seguintes 
ácidos inorgânicos: fluorídrico (HF), nítrico (HNO3), sulfúrico (H2SO4); ou seus sais que os liberem nas condições de uso do produto(ANVISA, 2010).

De maneira geral, os produtos de Risco I são categorizados como alvejantes; branqueadores; desincrustantes; detergentes; finalizadores (amaciantes, lustradores, ceras para pisos, facilitadores de passagem de roupas, polidores, engomadores de roupas, acidulantes, neutralizadores para lavagem de roupa); limpadores; neutralizadores de odores; polidores de metais; produtos para pré-lavagem e póslavagem; removedores; sabões; saponáceos e outros (com exceção daqueles que possuem valor de pH extremo. Enquanto que os de Risco II são categorizados como: Desinfetantes, Desodorizantes, Esterilizantes, Algicidas para piscinas, Fungicidas para piscinas, Desinfetante de água para o consumo humano, Água sanitária, Produtos biológicos, Inseticidas, Raticidas, Jardinagem amadora e Repelentes (ANVISA, 2016).

As duas categorias de produto, tanto os de Risco I quanto os de Risco II não podem conter em sua composição componente que apresente efeitos comprovadamente mutagênicos, teratogênicos ou carcinogênicos para mamíferos. Nenhuma das duas classes pode também, apresentar componentes com valores de DL50 oral para ratos inferior a $2000 \mathrm{mg} / \mathrm{kg}$ de peso corpóreo para produtos líquidos e inferior a 500mg/kg de peso corpóreo para produtos sólidos (ANVISA, 2010).

\subsubsection{Principais componentes}

A sistematização de informações existentes sobre substâncias químicas - é feita pelo Chemical Abstract Service (CAS), uma divisão da Sociedade Americana de Química (American Chemical Society), que possui uma equipe de cientistas altamente treinados que encontra, coleta, organiza e divulga publicamente todas as informações sobre uma substância química, criando uma valiosa coleção de um conteúdo que é vital para a inovação em todo o mundo. O CAS mantém uma imensa base de dados de substâncias químicas. Cada substância desta base recebe um número, definido como número CAS e esse se torna o mais importante meio de identificação desta substância. 
Os números de registro CAS são cadastrados desde 1907. No ano de 2015 a quantidade de números CAS registrados chegou a 100.000 .00 e, no ano de 2014, foram cadastradas mais substâncias químicas do que no período de 1960 a 1990 (CAS, 2016).

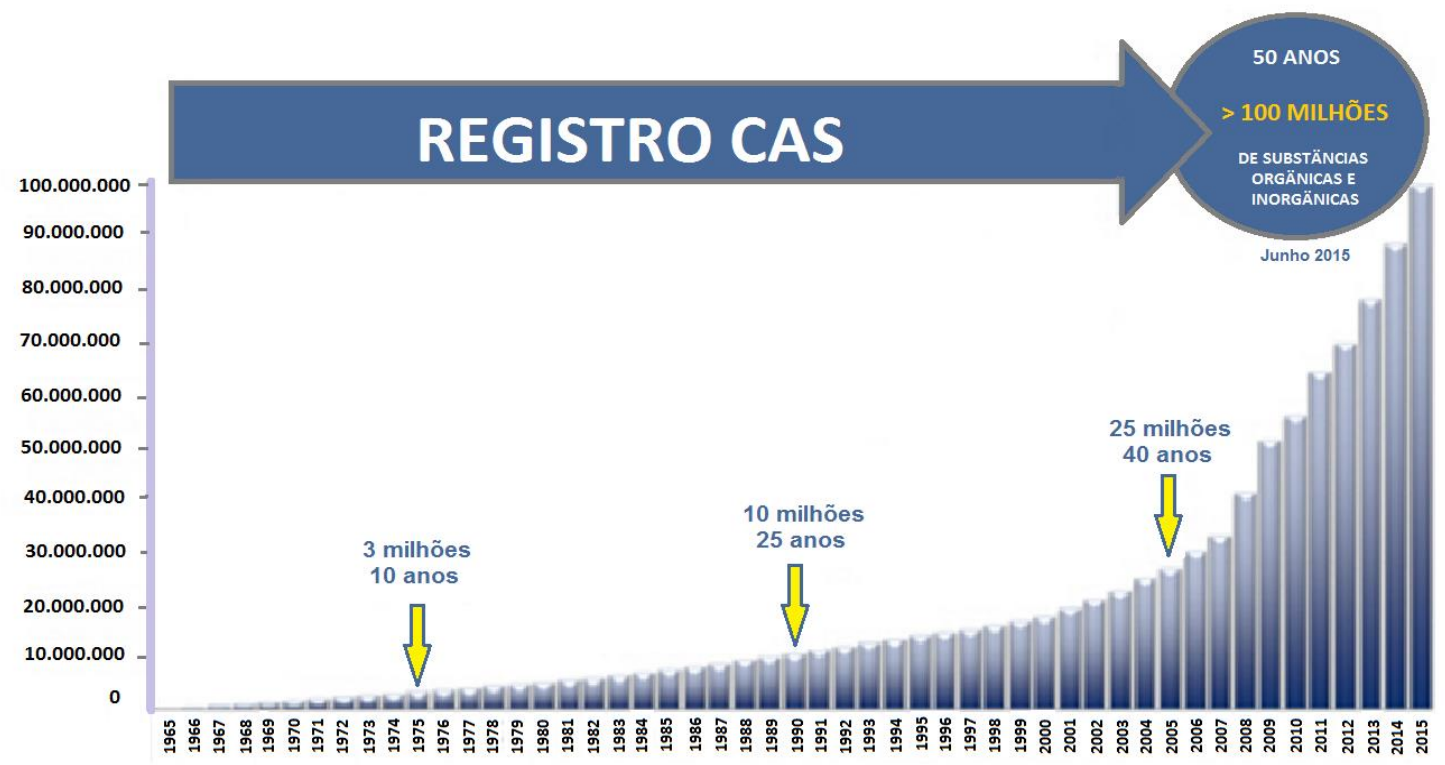

Figura 5- Quantidades de registros de números CAS no decorrer dos anos. Adaptado de (CAS, 2016).

Dentre todas estas substâncias cadastradas anualmente no CAS, muitas são utilizadas como agentes de limpeza. Especialistas químicos da indústria de saneantes estão constantemente estudando e testando novas substâncias para serem utilizadas em suas formulações.

Os agentes de limpeza são basicamente compostos de: componente(s) ativo(s), aditivo(s) e geralmente, água, dependendo da sua funcionalidade (WOLKOFF et al., 1998). Alguns dos principais grupos de componentes ativos são mostrados na tabela seguinte:

\begin{tabular}{|l|l|}
\hline $\begin{array}{l}\text { Componentes ativos } \\
\text { Essenciais para a função técnica do produto. }\end{array}$ \\
\hline $\begin{array}{c}\text { SURFACTANTES (OU TEN- }- \\
\text { SOATIVOS) }\end{array}$ & $\begin{array}{l}\text { são os principais componentes da maioria dos agentes de limpeza. } \\
\text { Sua função é diminuir a tensão de superfície da água e, com isso, } \\
\text { adicionar a característica do agente de limpeza. }\end{array}$ \\
\hline
\end{tabular}




\begin{tabular}{|c|c|}
\hline BASES & $\begin{array}{l}\text { possuem o efeito de dissolver as gorduras. Também se ligam para } \\
\text { melhorar o efeito de outras substâncias por meio da regulação do pH } \\
\text { da solução, como por exemplo os surfactates. } \\
\text { Exemplos: metassilicatos, dissilicatos, carbonato de sódio, carbonato } \\
\text { de cálcio, hidróxido de potássio e hidróxido de sódio. }\end{array}$ \\
\hline ÁCIDOS & $\begin{array}{l}\text { possuem o efeito de dissolver o cálcio. Substâncias ácidas também } \\
\text { podem agir como desinfetantes. } \\
\text { Exemplos: ácido fosfórico, ácido acético, ácido peracético, áido oxá- } \\
\text { lico, ácido cítrico, ácido fórmico e ácido sulfâmico. }\end{array}$ \\
\hline $\begin{array}{l}\text { AGENTES COMPLEXANTES } \\
\text { OU "AMACIANTES DE } \\
\text { ÁGUA" }\end{array}$ & $\begin{array}{l}\text { adicionados para dissolver e dar liga ao cálcio, magnésio e outros } \\
\text { íons metálicos, como os íons que diminuem o efeito do surfactante. } \\
\text { Exemplos: tripolifosfato, zeólito, citratos, policarboxilatos, NTA (ácido } \\
\text { nitriloacético) e EDTA (ácido etilenodiamino tetra-acético). }\end{array}$ \\
\hline DESINFETANTES & $\begin{array}{l}\text { a principal finalidade do uso de desinfetantes é destruir as bactétias } \\
\text { e outros microorganismos. São usados em superfícies quando uma } \\
\text { limpeza ou esterilização especial são requeridos, como por exemplo } \\
\text { em hospitais. Os componentes ativos de desinfetantes liberam cloro } \\
\text { (hipocloritos, álcoois (etanol e isopropanol), aldeídos (formaldeídos e } \\
\text { glutaraldeídos) e compostos quaternários de amônia (cloreto de ben- } \\
\text { zalcônio). Compostos que liberam oxigênio e enzimas também po- } \\
\text { dem ser usados para esse fim. }\end{array}$ \\
\hline $\begin{array}{l}\text { LIMPADORES DE SUPERFÍ- } \\
\text { CIE }\end{array}$ & $\begin{array}{l}\text { esse componente pode ser dividido em diversos subgrupos. Dentre } \\
\text { eles, os produtos para lavar superfície e ceras são agentes com uma } \\
\text { proporção equilibrada de componentes de limpeza e componentes de } \\
\text { manutenção de superfície, formando uma película de proteção nas } \\
\text { superfícies cuja função é proteger o piso contra a destruição química } \\
\text { ou o desgaste pelo uso, ao mesmo tempo em que facilitam a limpeza } \\
\text { devido ao efeito antiestático que alguns possuem. O efeito da película } \\
\text { protetora geralmente é formado por polímeros acrílicos, polietileno e } \\
\text { cera. Para se aplicar uma nova camada de cera no piso, é necessário } \\
\text { usar removedor para remover os resíduos da cera antiga. Esses re- } \\
\text { movedores são emulsões aquosas de etanolaminas, éter glicol, ten- } \\
\text { soativos, conservantes e sal alcalino ou metassilicato. A maior parte } \\
\text { dos produtos empregados como polidores e removedores contêm } \\
\text { substâncias potencialmente perigosas, tais como alergênicos, carci- } \\
\text { nogênicos, neurotóxicos ou tóxicos para a reprodução humana. }\end{array}$ \\
\hline SOLVENTES & $\begin{array}{l}\text { usados para dissolver as substâncias gordurosas. São usados para } \\
\text { promover a homogeinidade do produto. } \\
\text { Exemplos: álcoois (propanol e etanol) e éteres glicóis. }\end{array}$ \\
\hline
\end{tabular}




\begin{tabular}{|c|l|}
\begin{tabular}{|c|} 
Aditivos \\
Os aditivos não são essenciais para a função técnica do produto.
\end{tabular} \\
\hline $\begin{array}{c}\text { PERFUMES OU FRA- } \\
\text { GRÂNCIAS }\end{array}$ & $\begin{array}{l}\text { são usados para oferecer ao produto um odor agradável ou mascarar } \\
\text { um odor desagradável. Grande parte das fragrâncias e perfumes é } \\
\text { listada como alergênicos. }\end{array}$ \\
\hline CORANTES E PIGMENTOS & usados para dar cor aos produtos. \\
\hline CONSERVANTES & $\begin{array}{l}\text { inibem crescimento microbiano durante o armazenamento e o uso de } \\
\text { um produto, e servem, portanto, para prolongar a sua vida útil. Os } \\
\text { conservantes freqüentemente criam problemas no ambiente de tra- } \\
\text { balho, uma vez que muitos deles são considerados sensibilizantes. } \\
\text { Exemplos de sensibilizantes: isotiazolinonas e formaldeído (que além } \\
\text { do efeito alergênico, também é considerado carcinogênico categoria } \\
\text { 3). }\end{array}$ \\
\hline INIBIDORES DE & protegem as superfícies metálicas. \\
\hline CORROSÃO &
\end{tabular}

Quadro 4 - Composição básica de um produto de limpeza. FONTE : Adaptado de (WOLKOFF et al., 1998)

A imagem abaixo representa a composição típica de um produto desinfetande, com os componentes e cada uma de suas faixas de concentração presentes no produto final.

\begin{tabular}{lll}
\hline Component & $\begin{array}{l}\text { Concentration } \\
(\% \mathrm{w} / \mathrm{w})\end{array}$ & Examples of compounds \\
\hline Disinfectant (active substance) & $0.1-10$ & $\begin{array}{l}\text { Benzalkonium chloride } \\
\text { Sodium hypochlorite } \\
\text { Benzenesulphonic acid, dodecyl-, sodium salt }\end{array}$ \\
Surfactant & $0.1-10$ & Sodium hydroxide \\
Base & $0.1-25$ & Potassium hydroxide \\
Complexing agent & $5-30$ & Pentasodium triphosphate \\
Corrosion inhibitor & $1-10$ & EDTA \\
Solvent & $0.1-10$ & Disodium metasilicate \\
Perfume & $0.002-1$ & 2-Propanol \\
Pigment & $0.01-2$ & Citrus oils, eucalyptus oil \\
Acid & $0.1-35$ & Phosphoric acid \\
Diluent & $15-95$ & Citric acid \\
\hline
\end{tabular}

Figura 6 - Composição típica de um desinfetante

É possível perceber que muitas das substâncias químicas presentes na composição de saneantes podem provocar fortes impactos ambientais e graves danos 
à saúde humana. O manuseio inadequado de produtos de limpeza pode ocasionar efeitos adversos com diversos graus de severidade, causando dor e desconforto para o trabalhador e, em alguns casos, comprometimento laboral (CORREIA et al., 2013).

\subsubsection{Efeitos à saúde}

O risco oferecido por produtos de limpeza está relacionado com a toxicidade das substâncias químicas e suas concentrações nos produtos. Trabalhadores da área de saúde, principalmente os que atuam nos hospitais, são constantemente expostos a esses produtos e, consequentemente submetidos aos riscos trazidos por eles, pois é necessária a limpeza e desinfecção frequente das superfícies, dos materiais e dos equipamentos desses ambientes (SANTOS et al., 2011). A exposição à produtos de limpeza é comum tanto nos ambientes de trabalho quanto dentro das casas e as mulheres estão mais propensas a essa exposição do que os homens (DUMAS et al., 2014).

Entre os desinfetantes registrados que estão disponíveis para o consumidor, os ingredientes mais comuns são o amônio quaternário e o hipoclorito de sódio (BONDI, 2011). O hipoclorito de sódio é classificado como corrosivo de acordo com a Lista de Substâncias Perigosas da Europa. Há diversos estudos presentes na literatura que mostram os efeitos à saúde devido à exposição ao hipoclorito e a maioria dos estudos descreve problemas de dermatite de contato (WOLKOFF et al., 1998). Os compostos de amônio quaternário têm sido amplamente utilizados como preservativos em produtos domésticos, como sabonetes, pomadas, desinfetantes e outros produtos saneantes. Estudo realizado com limpadores de banheiro contendo amônio quartenário, mais especificamente o cloreto de benzalcônio, apresentaram evidências de induzir asma ocupacional (BERNSTEIN et al., 1994).

Os desinfetantes podem conter outros componentes que causam sérios problemas crônicos de saúde, tais como boratos que são considerados tóxicos para a reprodução humana. Há evidências de que os ingredientes ativos dos desinfetantes convencionais além de sérios problemas à saúde humana, podem contribuir para a poluição do ar e para bioacumulação e toxicidade à reprodução em animais (BONDI, 2011). 
Há uma série de estudos que analisa os produtos saneantes no ambiente de trabalho pelo seu potencial de causar asma (ARIF; DELCLOS, 2012; CASAS et al., 2013; DODSON et al., 2012; DUMAS et al., 2014; MOUAL et al., 2014; PECHTER et al., 2005; ROSENMAN et al., 2003; VIZCAYA et al., 2013).

Asma é uma doença crônica (exposição repetida) dos pulmões que causa dificuldades de respiração. Pessoas diagnosticadas com asma possuem maior sensibilidade nas vias aéreas, que podem ficar irritadas e inflamadas quando substâncias potencialmene causadoras de asma são inaladas. Por causa desta inflamação, os músculos ao redor das vias aéreas se contraem, os tecidos incham e ocorre excesso da produção de muco, tudo isso dificultando a pessoa a inspirar e expirar o ar fresco para dentro dos pulmões. Já a asma laboral é causada por um agente que a pessoa entra em contato no ambiente de trabalho. Geralmente esses agentes são inalados na forma de gáses, poeira, fumos ou vapores e são classificados como sensibilizantes ou irritantes. A asma laboral pode ser de dois tipos, a asma ocupacional e a asma agravada pelo trabalho. Asma ocupacional é o termo usado para descrever o tipo de asma que é induzida por uma substância sensibilizante ou irritante no ambiente de trabalho ( WORKPLACE SAFETY \& PREVENTION SERVICES; OCCUPATIONAL HEALTH CLINICS FOR ONTARIO WORKERS., 2010).

Vários outros agentes de limpeza como cloroexidina, glutaraldeído, formaldeído, isotialinona e cloramina foram descritos por causar asma ocupacional. Outro caso relatado é de um farmacêutico que teve seu primeiro ataque de asma aos 22 anos de idade após cloroxileno ser derramado no chão. $O$ ataque foi associado com cianose e durou algumas horas. Ele notou que os sintomas retornaram ao entrar em contato com triclorofenol (BURGE; RICHARDSON, 1994). 


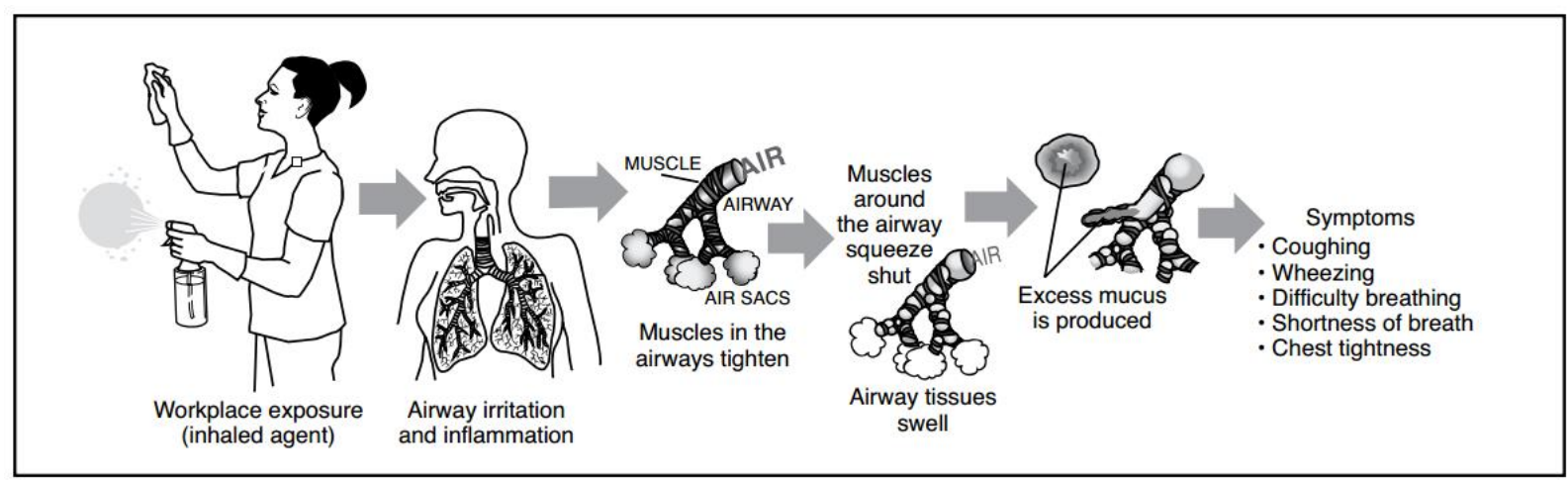

Figura 7 - Efeitos respiratórios causados por agentes de limpeza (WORKPLACE SAFETY \& PREVENTION SERVICES; OCCUPATIONAL HEALTH CLINICS FOR ONTARIO WORKERS, 2010)

Além dos problemas respratórios que os saneantes podem causar, uma revisão com 1250 substâncias usadas em produtos de limpeza mostrou também que 49 destas substâncias (4\%) são conhecidamente causadoras de dermatite de contato (ROSENMAN et al., 2003), outro problema bastante comum dos produtos saneantes.

Em adição aos efeitos à saúde, também são relatados efeitos prejudiciais ao meio ambiente pelo grande uso de produtos de limpeza. Uma lista com os ingredientes de detergentes mais relevantes, ou seja, consumidos em mais de 100 toneladas por ano, foi elaborada em 1991 pela NVZ (Associação Holandesa de Detergentes) baseada nos perigos ao meio ambiente. Dentre estas substâncias estão algumas com potencial efeito prejudicial ao meio ambiente, como as do quadro abaixo, que possuem valores de CL50 $<100 \mathrm{mg} / \mathrm{L}$, caracterizando, assim, uma classificação para perigoso ao meio ambiente segundo o GHS.

\begin{tabular}{|c|c|c|}
\hline Ingrediente & $\begin{array}{c}\text { Toneladas por } \\
\text { ano (em 1991) }\end{array}$ & CL50 (mg/L) \\
\hline $\begin{array}{c}\text { Linear } \\
\text { alquilbenzeno } \\
\text { sulfonato }\end{array}$ & 16.154 & $4(3,2-9,2)$ \\
\hline $\begin{array}{c}\text { Álcool etoxilado } \\
\text { Álcool etoxilado } \\
\text { sulfato }\end{array}$ & 8.934 & $4(0,6-460)$ \\
\hline
\end{tabular}

\footnotetext{
${ }^{4}$ CL50 = Concentração letal que mata $50 \%$ da população de organismo estudada
} 


\begin{tabular}{|l|l|l|}
\hline Sabão & 13.187 & $20(6,7-150)$ \\
\hline
\end{tabular}

Quadro 5 - Substâncias utilizadas em grande escala para produção de saneantes e seu potencial de causar efeitos prejudiciais ao meio ambiente (FEIJTEL; PLASSCHE, 1995)

Os surfactantes, assim como outros ingredients de detergentes são constituintes comuns de efluentes municipais e domésticos e podem ser tóxicos para os organismos aquáticos. Estudos envolvendo os efeitos tóxicos de surfactantes no meio ambiente foram muitos no passar dos anos, mas os efeitos dos detergentes como um todo, foram raramente considerados. Os vários componentes de um detergente podem interagir entre si de forma antagônica, aditiva ou sinérgica em relação à toxicidade no meio ambiente aquático. Os estudos comprovaram que o detergente Ariel prejudica a morfologia, fisiologia e bioquimica das algas Eugleno gracilis (AZIZULLAH; RICHTER; HÄDER, 2011).

O quadro 6, apresentado a seguir, indica de forma esquemática os principais perigos para seres humanos representados por alguns agentes químicos presentes em produtos saneantes.

\begin{tabular}{|c|c|}
\hline $\begin{array}{l}\text { Hipoclorito de sódio } \\
\text { (alvejantes) }\end{array}$ & Provoca irritação de olhos e pulmões. \\
\hline $\begin{array}{c}\text { Destilados do petróleo } \\
\text { (polidores de meais) }\end{array}$ & $\begin{array}{l}\text { Mesmo uma exposição por curto período de tempo pode causar tempora- } \\
\text { riamente visão turva. Uma exposição por período mais longo pode afetar } \\
\text { o sistema nervoso, pele, rins e olhos. }\end{array}$ \\
\hline $\begin{array}{c}\text { Amônia } \\
\text { (limpa vidros) }\end{array}$ & $\begin{array}{l}\text { Pode causar irritação à pele e aos pulmões. Se misturado com cloro, li- } \\
\text { bera gás tóxico cloroamina. A exposição a esse gás, mesmo por curto } \\
\text { período de tempo, pode causar tosse, parada respiratória e danos aos } \\
\text { pulmões. Os asmáticos são particularmente vulneráveis aos vapores } \\
\text { desse gás. }\end{array}$ \\
\hline
\end{tabular}




\begin{tabular}{|c|c|}
\hline $\begin{array}{l}\text { Fenol e Cresol } \\
\text { (desinfetantes) }\end{array}$ & $\begin{array}{l}\text { Corrosivo. Pode causar diarréia, vertigem, tontura e danos ao fígado e } \\
\text { aos rins. }\end{array}$ \\
\hline $\begin{array}{l}\text { Nitrobenzeno } \\
\text { (lustra-móveis e ceras para } \\
\text { o chão) }\end{array}$ & $\begin{array}{l}\text { Pode provocar dificuldades respiratórias, vômitos e até a morte. essa } \\
\text { substância está associada a câncer e defeitos de nascimento. }\end{array}$ \\
\hline $\begin{array}{l}\text { Formaldeído } \\
\text { (matéria-prima de muitos } \\
\text { produtos caseiros, tais como } \\
\text { móveis de madeira compen- } \\
\text { sada) }\end{array}$ & $\begin{array}{l}\text { Provável carcinogênico humano. Um nível de formaldeído no ar a 0,1ppm } \\
\text { pode causar lacrimejamento, sensação de ardência nos olhos, nariz e gar- } \\
\text { ganta, dificuldades para respirar, náusea, tosse, pressão no peito, racha- } \\
\text { duras na pele e reações alérgicas. }\end{array}$ \\
\hline $\begin{array}{l}\text { Percloroetileno ou solven- } \\
\text { tes 1-1-1 tricloroetano } \\
\text { (lavagem à seco, removedo- } \\
\text { res de manchas, limpadores } \\
\text { de carpete) }\end{array}$ & $\begin{array}{l}\text { Provoca irritações nos olhos, pele e pulmões. Pode prejudicar o fígado e } \\
\text { os rins se for ingerido. O percloroetileno pode causar câncer em alguns } \\
\text { animais de laboratório e é considerado um provável carcinógeno humano. } \\
\text { Pode se acumular e persistir nos tecidos gordurosos humanos e nas lac- } \\
\text { tantes. }\end{array}$ \\
\hline $\begin{array}{l}\text { Naftaleno ou paradicloro- } \\
\text { benzeno } \\
\text { (bolinhas de naftalinas e sa- } \\
\text { pólios) }\end{array}$ & $\begin{array}{l}\text { Os vapores do naftaleno podem irritar os olhos, a pele e o sistema respi- } \\
\text { ratório. A exposição crônica ao naftaleno pode causar danos ao fígado, } \\
\text { rins, pele e sistema nervoso central. O paradiclorobenzeno é um provável } \\
\text { carcinógeno que também pode afetar o sistema nervoso central, fígado e } \\
\text { rins. Uma alta concentração dos seus vapores pode irritar os olhos, nariz, } \\
\text { garganta e pulmões. }\end{array}$ \\
\hline $\begin{array}{l}\text { Ácido hidroclorídrico ou } \\
\text { sulfato ácido de sódio } \\
\text { (sapólios) }\end{array}$ & $\begin{array}{l}\text { Ambos podem causar queimaduras na pele, vômitos, diarréia e queima- } \\
\text { ção no estômago se ingeridos. Também podem causar cegueira se des- } \\
\text { cuidadamente caírem nos olhos. }\end{array}$ \\
\hline $\begin{array}{l}\text { Formaldeído, fenol e pen- } \\
\text { taclorofenol } \\
\text { (sprays) }\end{array}$ & Qualquer tipo de aerossóis pode irritar os pulmões. \\
\hline
\end{tabular}

Quadro 6 - Substâncias usadas na composição de saneantes e os potenciais perigos à saúde. Adaptado de (CORRÊA, 2005) 


\section{OBJETIVOS}

\subsection{Geral}

O propósito desse trabalho foi analisar as particularidades envolvidas no setor de saneantes e desenvolver um roteiro/guia para classificação do GHS destinado especificamente a esse setor.

\subsection{Específicos}

$\checkmark \quad$ Identificar matérias-primas da indústria de saneantes e relacionar os potenciais riscos da exposição a esses produtos;

$\checkmark$ Detalhar procedimentos para classificação do GHS, explicando os critérios e considerando as especificidades dessa categoria de produtos;

$\checkmark \quad$ Desenvolver um roteiro de classificação destinado ao setor;

$\checkmark \quad$ Exemplificar a utilização do roteiro para um caso típico;

$\checkmark \quad$ Contribuir para a segurança do trabalhador, para a proteção do consumidor e para a manutenção do meio ambiente. 


\section{METODOLOGIA}

O presente estudo é de natureza qualitativa, envolvendo a análise da legislação brasileira para produtos saneantes e os critérios de classificação do GHS.

O passo inicial foi levantar os principais problemas de comunicação de risco presentes nas indústrias de saneantes. Foram pesquisadas e coletadas na internet Fichas de Segurança de produtos saneantes para serem avaliadas a qualidade e precisão com que esses documentos são elaborados pelos profissionais da indústria.

Em seguida, avaliou-se as exigências estabelecidas pela Anvisa para produção e comercialização de produtos saneantes, de acordo com a RDC 59, as quais foram listadas e, quando pertinentes, comparadas com os critérios de classificação de produtos estebelecidos pelo GHS. A revisão dos critérios e procedimentos de classificação e comunicação de perigos pressupostos pelo GHS teve como base a análise do conteúdo da 6ª edição do Purple Book. O conhecimento sobre GHS já é bem consolidado devido à experiência profissional de 4 anos da autora.

Posteriormente foi feita uma vasta pesquisa bibliográfica sobre os tipos de saneantes e seus componentes mais comumente utilizados. Estudos sobre os potenciais efeitos prejudiciais à saúde e ao meio ambientes desses componentes também foram realizados e tiveram seus resultados confirmados através de pesquisas em bases de dados internacionalmente conhecidas. Utilizou-se as informações das bases gratuitas e disponíveis para o público, como European Chemicals Agency (ECHA, 2016), European Chemical Substances Information System (ESIS, 2012), German Databases on Hazardous Susbtance - GESTIS (GESTIS, 2016), Toxicology Data Network (TOXNET, 2012), US Enviromental Protection Agency (USEPA, 2012a) e International Programme on Chemical (INCHEM, 2012) e Institut national de recherche et de sécurité (INRS, 2016) para reunir dados físico-químicos e estudos toxicológicos de substâncias usadas como matérias-primas de produtos saneantes.

Para a elaboração do roteiro de classificação do GHS baseou-se na publicação oficial da 6 edição do Purple Book, publicada em 2015. Foi consultada também a última versão da ABNT NBR 14725, norma brasileira que implementa os critérios do 
GHS no país, publicada em 2009, com sua versão corrigida em 2010. As particularidades dos saneantes foram levadas em conta para criar um roteiro eficiente e simplificado totalmente aplicável para o setor.

Conhecendo, então, as classes de perigo abrangidas pelo GHS e também as características das matérias-primas utilizadas para produção de saneantes, foram verificados quais dos perigos listados elo GHS são aplicáveis para o setor e foram elaborados fluxogramas a serem seguidos pela indústria de saneantes. No roteiro aqui listado constam os fluxogramas de aplicação para o produto final, pronto para comercialização. Para classificação de uma substância pura, consulte os critérios de classificação descritos no livro do GHS.

Para a criação dos fluxogramas foram tidos como modelo os fluxogramas presentes no Guia de Classificação GHS para Empresas, publicado pelo governo do Japão (JAPAN, 2013).

Para a classificação de uma mistura de substâncias, é essencial conhecer as classificações de perigo de cada um dos ingredientes e suas respectivas concentrações na mistura em porcentagem. Para a elaboração dos critérios de classificação citados no roteiro, foi utilizado substancialmente o GHS, descrevendo, quando existentes, as particularidades do setor de saneantes.

A classificação de cada um dos ingredientes do produto utilizado como exemplo no Anexo I foram buscadas nas bases de dados internacionais disponíveis gratuitamente na internet. Através destas informações, aplicou-se os cálculos de extrapolação, os métodos somatórios e/ou os limites de corte exemplificados nos fluxogramas.

\subsection{Elementos para elaboração do Roteiro}

Os elementos para elaboração do roteiro foram:

a) Legislações brasileiras:

Dentre elas, a mais importante para o objetivo do presente trabalho foi a Resolução da Diretoria Colegiada ํo 59 da Anvisa, a qual estabelece os critérios para 
registros e notificações de produtos saneantes. A partir desta legislação pudemos colher informações do que é permitido ou o que é proibido conter nas formulações de Saneantes.

b) Tipos de produtos saneantes:

Conhecer os tipos de produtos saneantes foi essencial para poder avaliar as classes de perigo existentes no GHS e excluir aquelas que realmente não eram aplicáveis ao setor, como por exemplo Explosivos e Carcinogênicidade - Categoria 1.

c) Critérios de classificação de misturas do GHS:

Avaliar os critérios de classificação do GHS foi importante para entender em quais categorias de produtos não podiam se enquadrar os saneantes.

d) Fluxogramas do Guia de Classificação do GHS para Empresas, do Japão:

Os fluxogramas do Guia do Japão foram tidos como modelo para elaboração do roteiro para saneantes. O intuito foi facilitar a aplicação do GHS na forma de fluxogramas e decisões lógicas. 


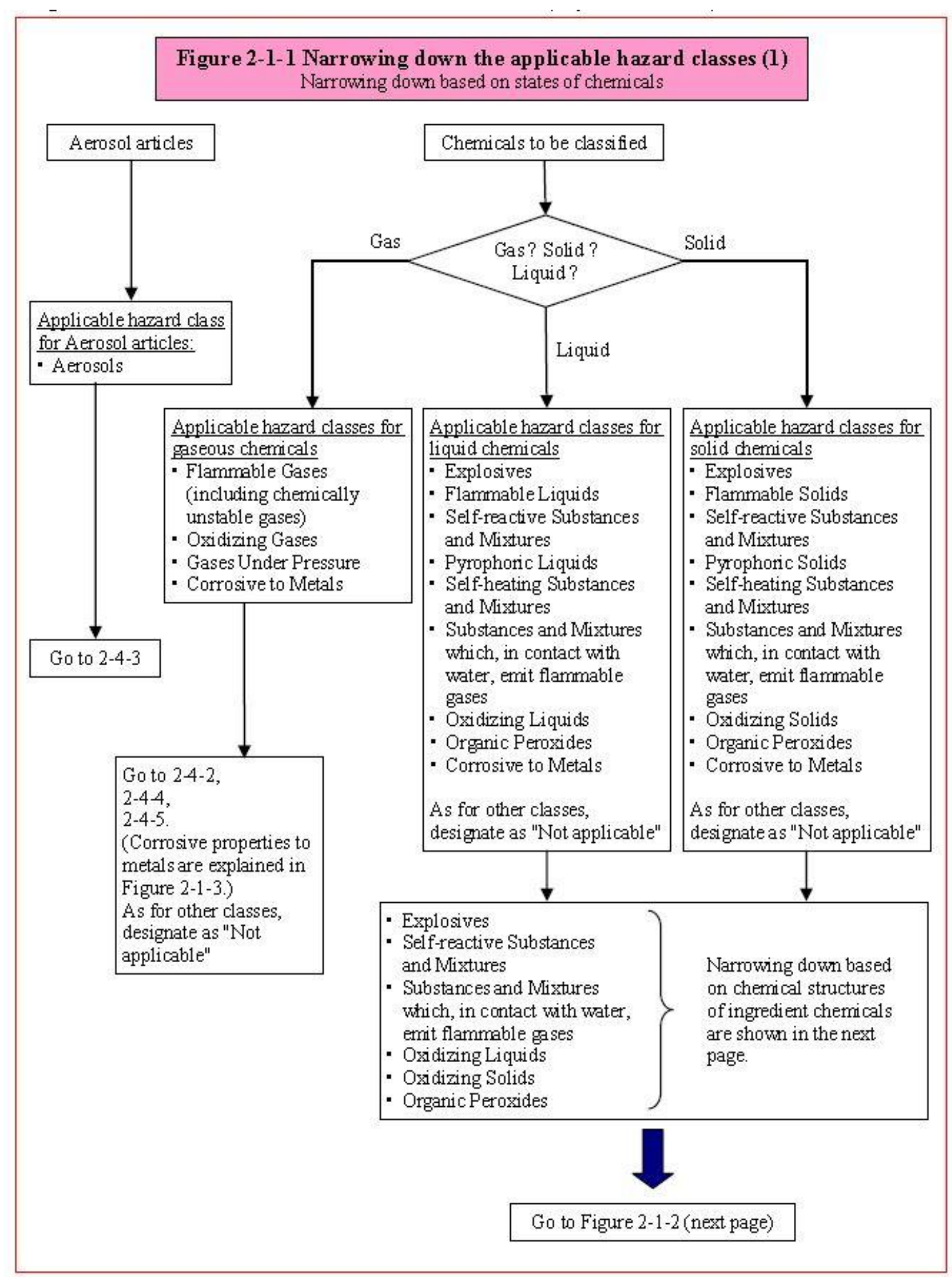

Figura 1-- Fluxograma do Guia do Japão que foi utulizado como modelo para desenvolvimento dos fluxogramas desse trabalho 


\section{ROTEIRO PARA APLICAÇÃO DO GHS PARA PRODUTOS SANEANTES}

Esse roteiro foi desenvolvido para auxiliar a classificação do GHS de produtos saneantes com o intuito de melhorar a qualidade das FDS, dos rótulos e, consequentemente, criar um sistema de comunicação eficiente no setor. É destinado a todos os tipos de produtos saneantes, mais espeficicamente, aos produtos finais, ou seja, as misturas de duas ou mais substâncias.

De acordo com o GHS, uma mistura é uma combinação ou uma solução de duas ou mais substâncias que não reagem entre si. Dentre os produtos saneantes, a grande maioria é, portanto, uma mistura. Por esse motivo, esse Roteiro contempla as etapas necessárias para classificação de misturas. Os critérios para classificação de substâncias puras podem ser encontrados no livro do GHS .

Previamente, foram divididos 3 grupos de Perigo, sendo eles: Perigos Físicos, Perigos à Saúde e Perigos ao Meio Ambiente. Cada um deles contém todas as Classes de Perigo aplicáveis ao setor de saneantes, com um fluxograma explicativo para cada uma delas.

É importante que se avalie todas as classes de perigo para cada produto saneante. Um produto pode ser classificado para mais de uma classe ao mesmo tempo.

Para utilizar o roteiro, é necessário seguir os seguintes passos:

\section{1ํ PASSO: Reunir informações sobre o produto que deseja classificar}

- Propriedades físico-químicas da mistura como um todo

Os dados relevantes para a classificação são: Ponto de Fulgor, Ponto de Ebulição, valor de $\mathrm{pH}$, viscosidade medida a $40^{\circ} \mathrm{C}$.

- Resultados de ensaios laboratoriais, se disponíveis

São relevantes estudos de oxidação, corrosão para metais, inflamabilidade, DL50 (oral e dérmica), CL50 (Inalatória e para organismos aquáticos - peixes, 
crustáceos e algas), CE50, CEr50, estudos de irritação à pele, estudos de sensibilização, possibilidade de afetar algum órgão específico, estudo de degradabilidade no meio ambiente, entre outros.

\section{- Informações sobre os componentes do produto}

É importante aqui, coletar todos os dados disponíveis para os ingredientes da mistura, para aplicá-los nos critérios de classificação do produto. São essenciais: a concentração dos ingredientes em porgentagem e a classificação GHS de cada um deles. É possível obter a classificação nas FDS fornecidas pelos fornecedores das matérias primas, caso estas estejam elaboradas corretamente de acordo com o GHS.

\section{2'PASSO: Verificar quais dos ingredientes estão abaixo das concentrações de corte-limite}

O GHS estabelece valores de limite de corte para cada um dos perigos, os quais devem ser seguidos para a classificação de uma mistura. A soma da concentração dos ingredientes classificados para um mesmo perigo que esteja abaixo dos limites de corte pode ser desconsiderada para o cálculo do perigo da mistura, com exceção de casos em que existam evidências de que um ingrediente contribui para o perigo da mistura mesmo estando em concentração abaixo do limite de corte. A tabela de limites de corte está apresentada abaixo:

\begin{tabular}{|l|c|}
\hline \multicolumn{1}{|c|}{ Classe de perigo } & Valor de limite de corte de concentração \\
\hline Toxicidade aguda oral, dérmica e inalatória & $\geq 1.0 \%$ \\
\hline Corrosão/irritação da pele & $\geq 1.0 \%$ \\
\hline Lesões oculares grave/irritação ocular & $\geq 1.0 \%$ \\
\hline Sensibilização respiratória/dérmica & $\geq 0.1 \%$ \\
\hline Mutagenicidade em células germinativas (categoria 1) & $\geq 0.1 \%$ \\
\hline Mutagenicidade em células germinativas (categoria 2) & $\geq 1.0 \%$ \\
\hline Carcinogenicidade & $\geq 0.1 \%$ \\
\hline Toxicidade reprodutiva & $\geq 0.1 \%$ \\
\hline $\begin{array}{l}\text { Toxicidade para órgão-alvo específico (exposição única) - Ca- } \\
\text { tegorias 1 e 32 }\end{array}$ & $\geq 1.0 \%$ \\
\hline $\begin{array}{l}\text { Toxicidade para órgão-alvo específico (exposição única) - Ca- } \\
\text { tegoria 3 }\end{array}$ & $\geq 20 \%$ \\
\hline Toxicidade para órgão-alvo específico (exposição repetida) & $\geq 1.0 \%$ \\
\hline
\end{tabular}




\begin{tabular}{|l|c|}
\hline Toxicidade por aspiração (categoria 1) & $\begin{array}{c}\geq 10 \% \text { de ingrediente (s) categoria } 1 \text { e visco- } \\
\text { sidade cinemática } \leq 20.5 \mathrm{~mm} 2 / \mathrm{s} \mathrm{a} 40^{\circ} \mathrm{C}\end{array}$ \\
\hline Toxicidade por aspiração (categoria 2) & $\begin{array}{c}\geq 10 \% \text { de ingrediente (s) categoria } 2 \text { e visco- } \\
\text { sidade cinemática } \leq 14 \mathrm{~mm} 2 / \mathrm{s} \mathrm{a} 40^{\circ} \mathrm{C}\end{array}$ \\
\hline Perigoso pro meio ambiente aquático & $\geq 1.0 \%$ \\
\hline
\end{tabular}

Tableau 1 - Valore de limite de corte para cada um dos perigos do GHS

\section{3o PASSO: Aplicar os fluxogramas}

Utilizando as informações coletadas no $1^{\circ}$ e $2^{\circ}$ passos, seguir os fluxogramas para cada uma das classes de perigo. Verificar se o produto é classificado e, se sim, encaixar na categoria adequada. Caso o produto não se encaixe em nenhum dos critérios estabelecidos para cada classe de perigo, esse não será classificado para determinada classe.

\section{PASSO: Listar os perigos do produto}

Após passar por todos os fluxogramas, listar cada uma das classes com suas respectivas categorias de perigo para o produto selecionado. Essa classificação é essencial para ser informada na seção 2 da FDS e no Rótulo. Um exemplo de aplicação do Roteiro está representado no Anexo I desse trabalho.

\section{PASSO: Comunicar os riscos do produto classificado}

Depois de classificar corretamente o produto é hora de elaborar a FDS e o rótulo para comunicar os perigos do produto aos trabalhadores. Esses documentos devem conter também as informações necessárias para mitigar os riscos, diminuir a exposição, proteger o trabalhador e o meio ambiente. 


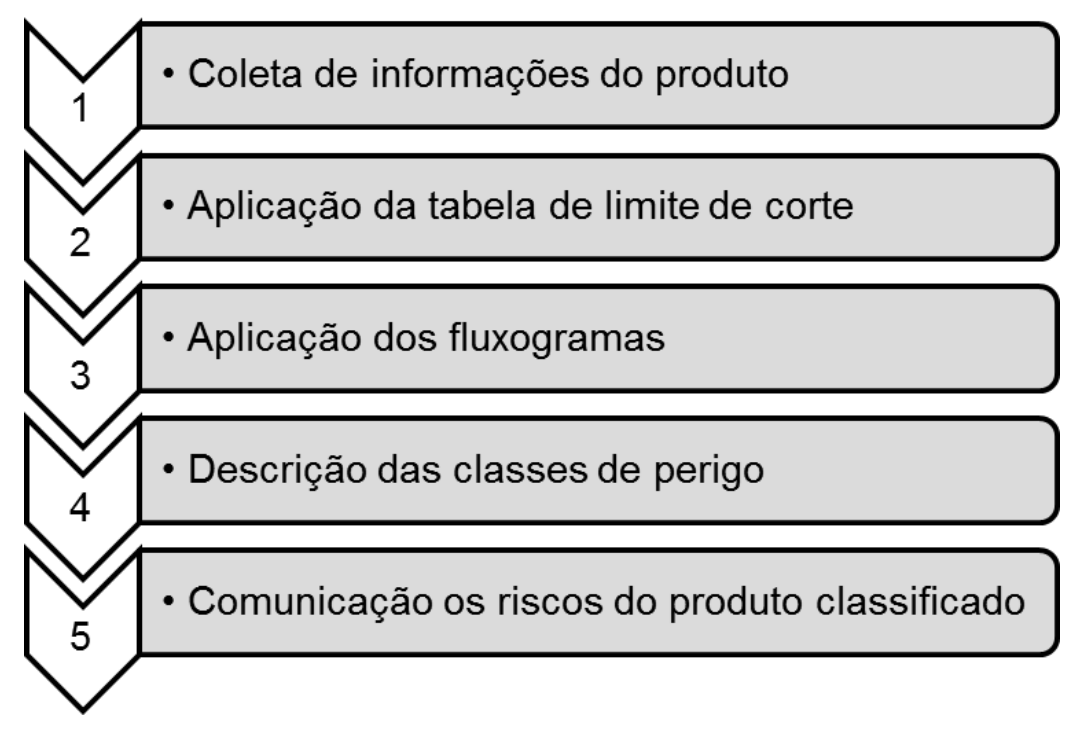

Figura 2 - Passos a serem seguidos desde a coleta de informações até a comunicação dos riscos de um produto

\subsection{Perigos Físicos}

Inicialmente, avaliando as classes de perigo existentes no GHS e as especificidades do setor de saneantes, percebeu-se que algumas classes de perigos físicos não precisavam ser abrangidas no roteiro, uma vez que não se aplicam para produtos saneantes:

$X$ Explosivos

X Gases Inflamáveis

X Gases Oxidantes

X Gases sob pressão

X Sólidos Inflamáveis

X Substâncias ou misturas autoreativas

X Substâncias ou misturas que apresentam auto-aquecimento

X Substâncias ou misturas que, em contato com a água, liberam gases inflamáveis 


\author{
X Líquidos Pirofóricos \\ X Sólidos Pirofóricos \\ X Peróxidos orgânicos
}

Portanto, as classes de perigo físico nas quais os produtos saneantes podem se enquadrar são:

Líquidos Inflamáveis. (Exemplo: removedores)

Líquidos oxidantes.( Exemplo: produto para limpeza de aço inox)

Sólidos oxidantes. (Exemplo: produto para limpeza de piscina)

Corrosivos para os metais. (Exemplo: produtos para desoxidar metais)

Aerossóis. (Exemplo: aromatizador de ambiente, inseticidas)

Os perigos físicos associados às misturas são avaliados por meio de propriedades físico químicas. Não é possível extrapolar os perigos físicos dos ingredientes para a mistura. Por exemplo, se uma mistura possui $30 \%$ de um ingrediente inflamável e 70\% de um ingrediente não inflamável, não é possível concluir se a mistura desses dois ingredientes será inflamável ou nao, a não ser avaliando o ponto de fulgor da mistura como um todo. Esse é um equívoco comum entre as indústrias na hora de preparar a FDS.

Porém, caso a mistura não possua em sua composição nenhum ingrediente classificado como inflamável, não é necessário determinar as propriedades de inflamabilidade, já que a possibilidade desta mistura ser inflamável, é nula. 


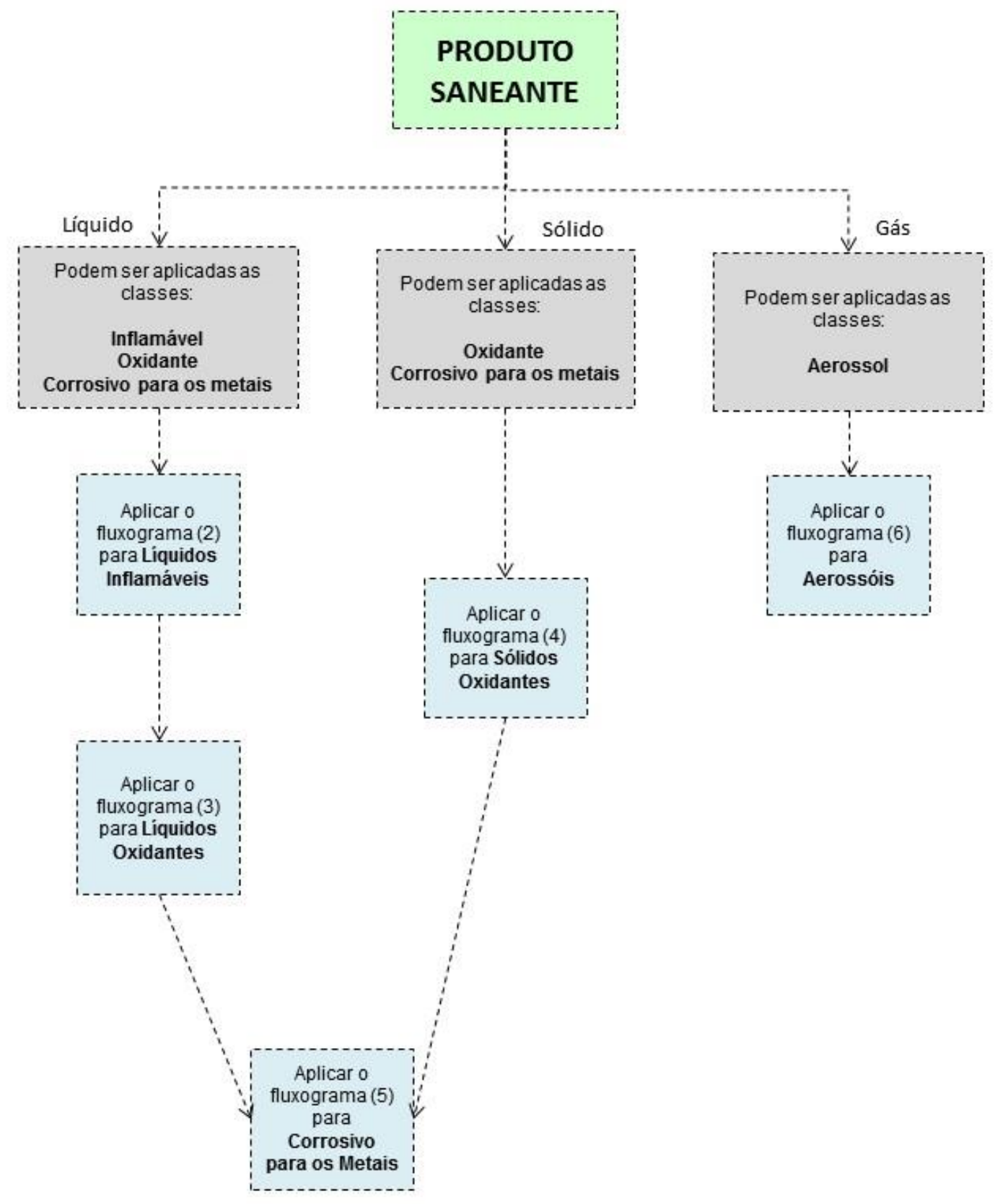

Fluxograma 1 - Perigos físicos que podem ser aplicados para produtos saneantes 


\subsubsection{Líquidos Inflamáveis}

Segundo o GHS, um líquido inflamável é aquele que possui um ponto de fulgor (PF) menor ou igual a 93ํ $\mathrm{C}$. Na categoria de saneantes, muitos produtos são enquadrados como líquidos inflamáveis.

Uma alternativa que pode ser útil para classificar o produto saneante como líquido inflamável é através do seu número ONU. Caso o produto possua um número ONU que tenha como classe ou subclasse de risco o número 3 (Líquidos Inflamáveis) para o transporte, esse será, também, classificado para o GHS. Nos critérios de classificação de perigos para transporte, a severidade do perigo, ao invés de ser separada por categorias, como no GHS, é dividida em Grupo de Embalagem, sendo o grupo de embalagem I destinado aos produtos que apresentam perigo alto. No grupo de embalagem II se enquadram os produtos com perigo médio, enquanto que o grupo III fica com os produtos de baixo perigo.

Para líquidos inflamáveis, os critérios para classificação no transporte, nos grupos de embalagem I, II e III são praticamente iguais aos critérios do GHS para classificação nas categorias 1,2 e 3 com exceção somente de $0,5^{\circ} \mathrm{C}$ de diferença nos limites de ponto de fulgor na categoria 3.

Esta comparação está representada no fluxograma 2, assim como os critérios para classificação de Líquidos Inflamáveis. Para maiores detalhes dos procedimentos para classificação nessa categoria de perigo, consultar capítulo 2.6 do GHS. 


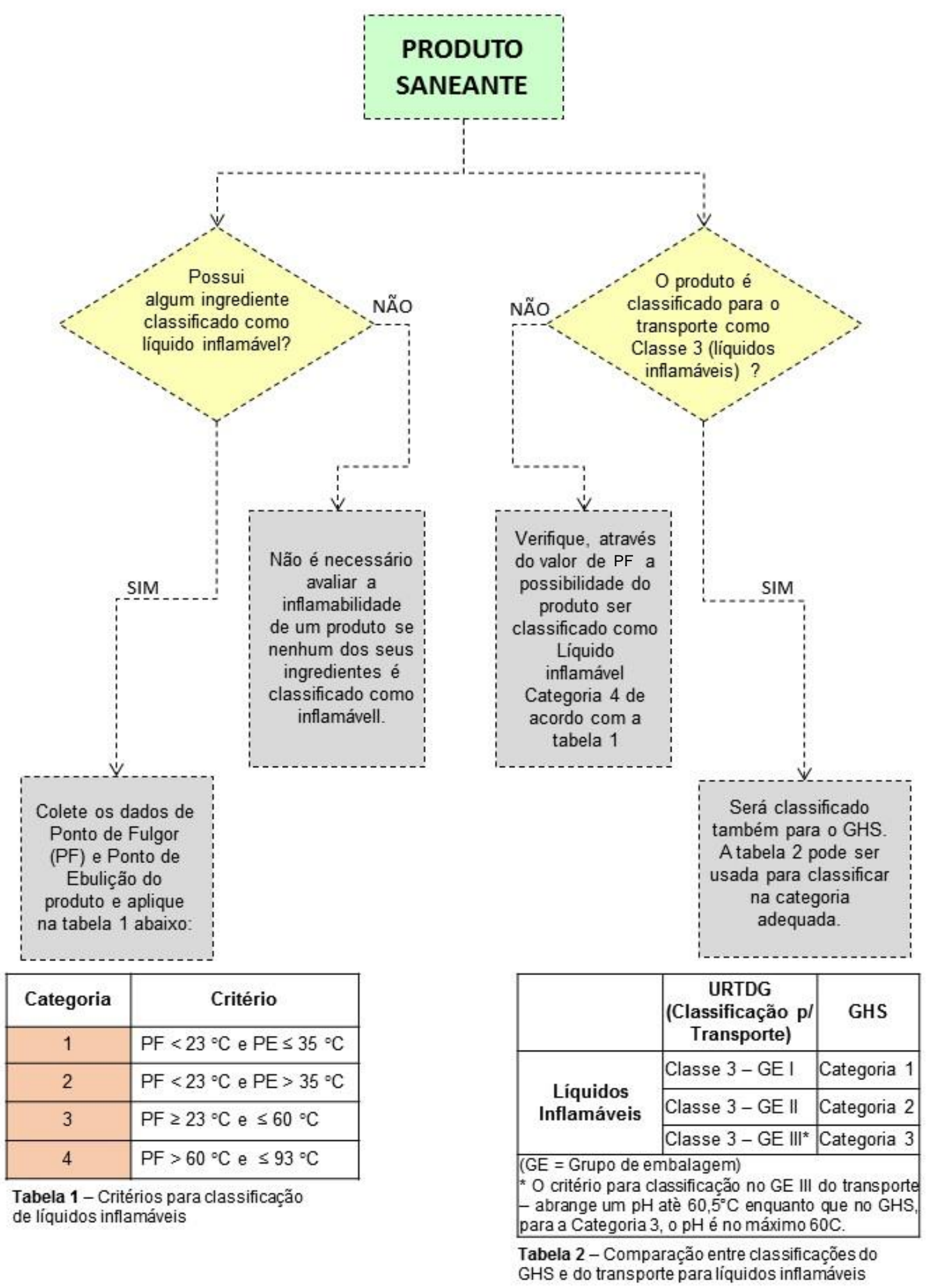

Fluxograma 2 - Decisão lógica para classificação de Líquidos Inflamáveis 


\subsubsection{Líquidos Oxidantes}

Um líquido oxidante é um líquido que, embora não seja necessariamente combustível por si só, pode, geralmente, liberar oxigênio, causar ou contribuir para a combustão de outro material. É também conhecido por Líquido Comburente.

O Fluxograma 3 apresenta os critérios para classificação de um produto como Líquido Oxidante. Para maiores detalhes dos procedimentos para classificação nessa categoria de perigo, consultar capítulo 2.13 do GHS. 


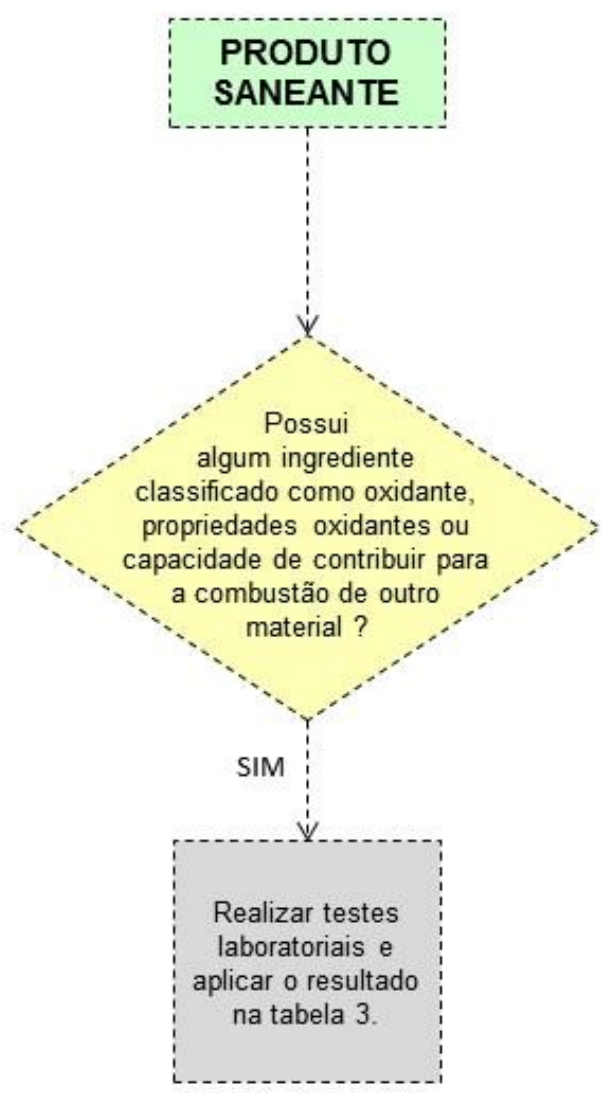

\begin{tabular}{|c|c|}
\hline Categoria & Critério \\
\hline 1 & $\begin{array}{c}\text { Qualquer substância ou mistura que, ensaiado com celulose em } \\
\text { proporção 1:1 (em massa), se inflama espontaneamente ou tem um } \\
\text { tempo médio de aumento de pressão inferior ao de uma mistura de } \\
\text { ácido perclórico } 50 \% \text { e celulose na proporção de 1:1 (em massa) }\end{array}$ \\
\hline 2 & $\begin{array}{c}\text { Qualquer substância ou mistura que, ensaiado com celulose em } \\
\text { proporção 1:1 (em massa), tem um tempo médio de aumento de } \\
\text { pressão inferior ou igual ao de uma mistura de clorato de sódio em } \\
\text { solução aquosa a 40\% e celulose, na proporção 1:1 (em massa), e } \\
\text { que não atende ao critério da categoria 1 }\end{array}$ \\
\hline 3 & $\begin{array}{c}\text { Qualquer substância ou mistura que, ensaiado com celulose na } \\
\text { proporção 1:1 (em massa), tem um tempo médio de aumento de } \\
\text { pressăo inferior ou igual ao de uma mistura de ácido nítrico em } \\
\text { solução aquosa a 65 \% e celulose, na proporção 1:1 (em massa), e } \\
\text { que não atende aos critérios das categorias 1 e 2 }\end{array}$ \\
\hline
\end{tabular}

Tabela 3-Critérios para classificação de líquidos oxidantes

Fluxograma 3 - Decisão lógica para classificação de Líquidos Oxidantes 


\subsubsection{Sólidos Oxidantes}

Um sólido oxidante é um sólido que, embora não seja necessariamente combustível por si só, pode, geralmente por liberar oxigênio, causar ou contribuir para a combustão de outro material. É também conhecido por Sólido Comburente.

Os critérios para classificação de Sólidos Oxidantes estão representados no Fluxograma 4. Para maiores detalhes dos procedimentos para classificação nessa categoria de perigo, consultar capítulo 2.14 do GHS. 


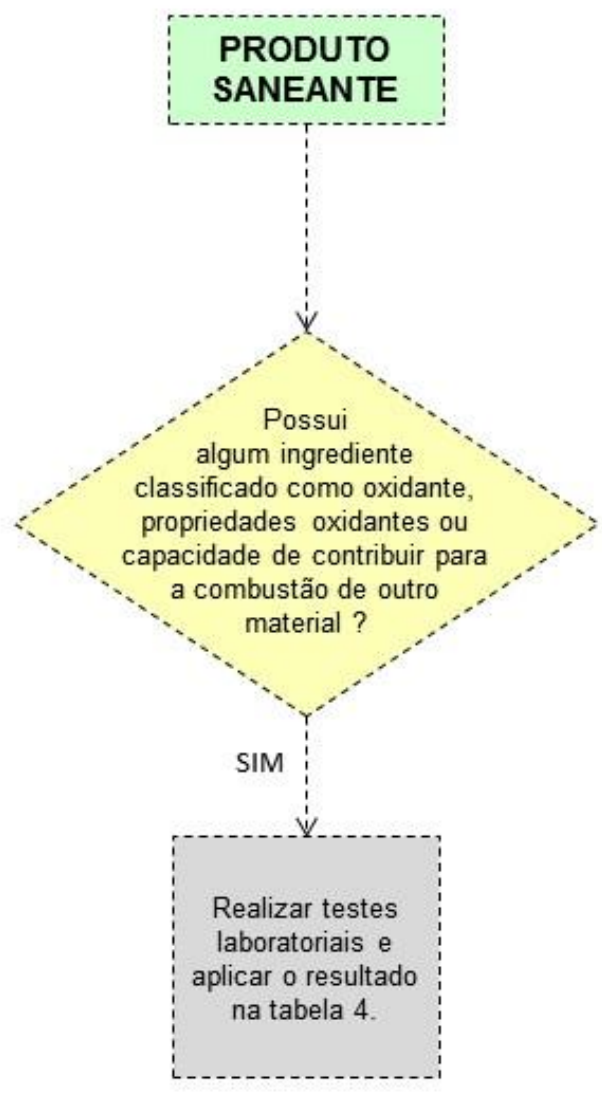

\begin{tabular}{|c|c|c|}
\hline Categoria & Critério aplicando o teste 0.1 & Critério aplicando teste 0.3 \\
\hline 1 & $\begin{array}{l}\text { Qualquer substáncia ou mistura que, ensaiada com celulose en } \\
\text { proporçăo } 4: 1 \text { ou } 1: 1 \text { (em massa), tem um tempo médio de } \\
\text { combustăo inferior ao tempo médio de combustăo de uma mistura. } \\
\text { de bromato de potássio e celulose na proporçăo } 3: 2 \text { (em massa) }\end{array}$ & $\begin{array}{l}\text { Qualquer substáncia ou mistura que, ensaiada com celulose em } \\
\text { proporçăo } 4: 1 \text { ou } 1: 1 \text { (em massa), tem um tempo médio de } \\
\text { combustăo maior ao tempo médio de combustăo de uma mistura } \\
\text { de peróxido de cálcio ecelulose na proporçăo } 3: 1 \text { (em massa) }\end{array}$ \\
\hline 2 & $\begin{array}{l}\text { Qualquer substáncia ou mistura que, ensaiada com celulose em } \\
\text { proporçăo } 4: 1 \text { ou } 1: 1 \text { (em massa), tem um tempo médio de } \\
\text { combustăo igual ou inferior ao tempo médio de combustăo de uma } \\
\text { mistura de bromato de potássio e celulose na proporçăo } 2: 3 \text { (em } \\
\text { massa), eque năo atenda ao critério da categoria } 1 \text {. }\end{array}$ & $\begin{array}{l}\text { Qualquer substáncia ou mistura que, ensaiada com celulose em } \\
\text { proporçắo } 4: 1 \text { ou } 1: 1 \text { (em massa), tem um tempo médio de } \\
\text { combustăo igual ou maior ao tempo médio de combustăo de uma } \\
\text { mistura de peróxido de cálcio e celulose na proporçắo } 1: 1 \text { (em } \\
\text { massa), e que nắo atenda ao critério da categoria } 1 \text {. }\end{array}$ \\
\hline 3 & $\begin{array}{l}\text { Qualquer substáncia ou mistura que, ensaiada com celulose en } \\
\text { proporçăo } 4: 1 \text { ou } 1: 1 \text { (em massa), tem um tempo médio de } \\
\text { combustăo igual ou inferior ao tempo médio de combustăo de uma } \\
\text { mistura de bromato de potássio e celulose na proporçăo } 3: 7 \text { (em } \\
\text { massa), e que năo atenda aos critérios das categorias } 1 \text { i e } 2 \text {. }\end{array}$ & $\begin{array}{l}\text { Qualquer substáncia ou mistura que, ensaiada com celulose em } \\
\text { proporçăo } 4: 1 \text { ou } 1: 1 \text { (em massa), tem um tempo médio de } \\
\text { combustăo igual ou maior ao tempo médio de combustăo de uma } \\
\text { mistura de peróxido de cálcio e celulose na proporçắo } 1: 2 \text { (em } \\
\text { massa), e que năo atenda aos critérios das categorias } 1 \text { e } 2 \text {. }\end{array}$ \\
\hline
\end{tabular}

Tabela 4 - Critérios para classificação de sólidos oxidantes

Fluxograma 4 - Decisão lógica para classificação de sólidos inflamáveis 


\subsubsection{Corrosivo para os metais}

Uma substâncias ou mistura corrosiva para os metais é aquela que, por ação química, pode danificar ou até destruir os metais.

Os critérios para classificação de Corrosivo para os metais estão representados no Fluxograma 5. Para maiores detalhes dos procedimentos para classificação nessa categoria de perigo, consultar capítulo 2.16 do GHS.

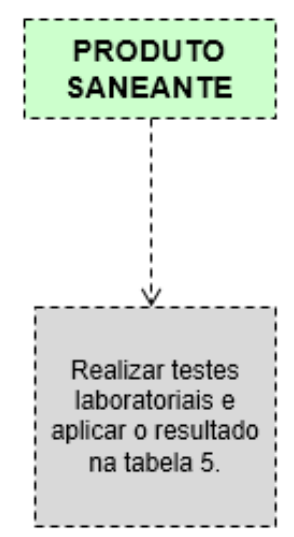

\begin{tabular}{|c|l|}
\hline Categoria & \multicolumn{1}{|c|}{ Criterio } \\
\hline \multirow{3}{*}{1} & $\begin{array}{l}\text { Taxa de corrosão em superfícies de aço ou } \\
\text { alumínio superiores a } 6,25 \mathrm{~mm} \text { por ano, a uma } \\
\text { temperatura de ensaio de } 55^{\circ} \mathrm{C} \text {, quando testado } \\
\text { em ambos os materiais. }\end{array}$ \\
\hline
\end{tabular}

Tabela 5 - Critério para classificação de corrosivo para os metais

Fluxograma 5 - Decisão lógica para classificação de Corrosivo para os metais

\subsubsection{Aerossóis}

Aerossol ou dispersor de aerossol, é qualquer recipiente não reutilizável de metal, vidro ou plástico contendo gás comprimido, liquefeito ou dissolvido sob pressão, com ou sem um líquido, uma pasta ou um pó e equipado com um dispositivo que permite a liberação do conteúdo na forma de partículas em suspensão sólidas ou 
líquidas ou na forma de gás, como espuma, pasta ou pó ou nos estados líquido ou gasoso (UNITED NATIONS, 2015)

Os aerossóis são classificados em uma das três categorias desta classe de perigo, dependendo das suas propriedades inflamáveis ou de seu calor de combustão. São considerados Aerossóis Categorias 1 ou 2 se tiverem mais de $1 \%$ de ingredientes classificados como inflamáveis de acordo com os critérios de Gases Inflamáveis, Líquidos Inflamáveis ou Sólidos Inflamáveis, descritos, respectivamente nos capítulos 2.2, 2.6 e 2.7 do GHS.

Os critérios para classificação de Aerossóis estão representados no Fluxograma 6. Aerossóis em forma de spray ou de espuma possuem critérios diferentes de classificação e também estão representados nos fluxogramas 7 e 8 . Para maiores detalhes dos procedimentos para classificação nessa categoria de perigo, consultar capítulo 2.3 do GHS 


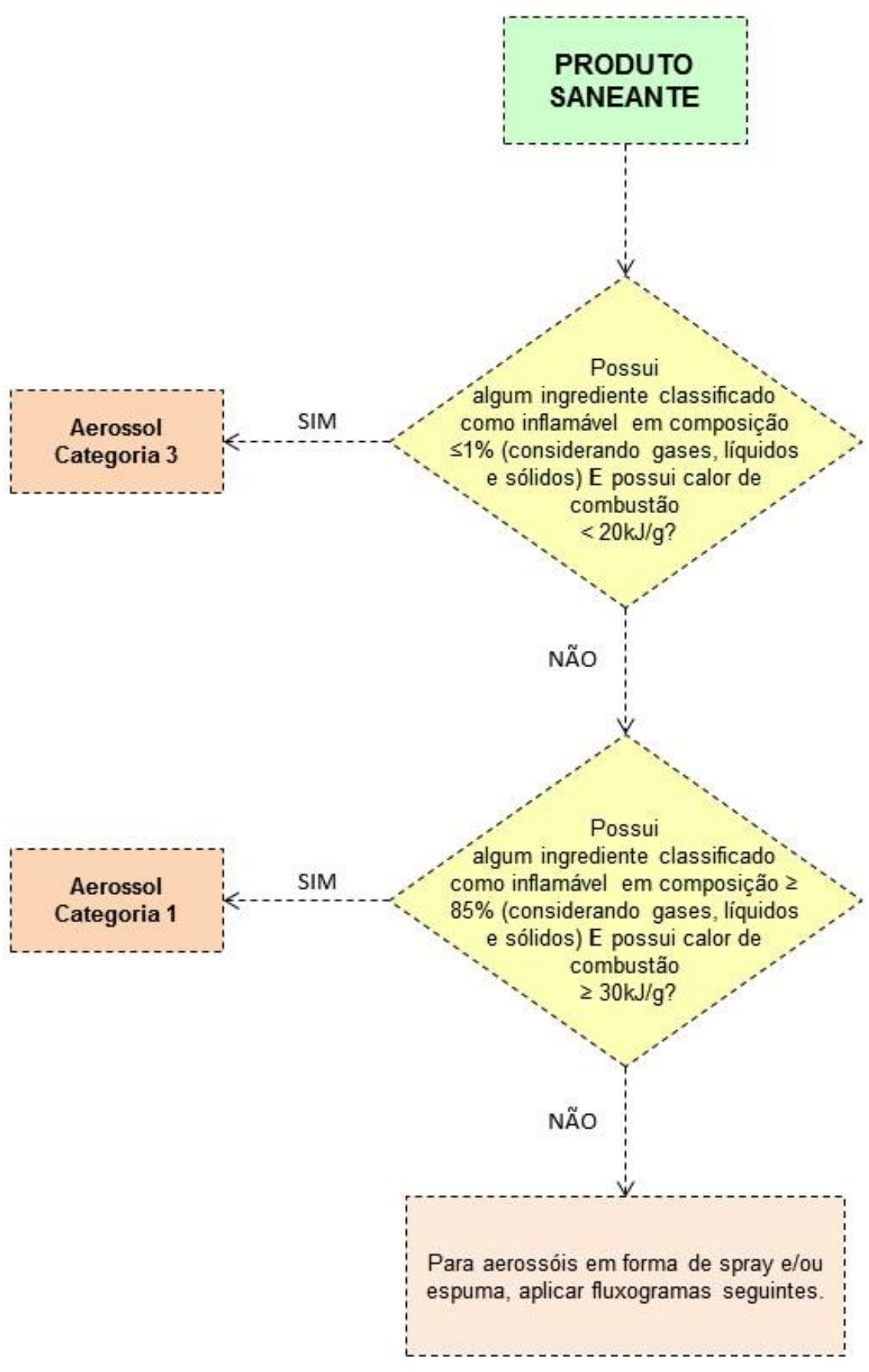

Fluxograma 6 - Decisão lógica para classificação de Aerossóis 


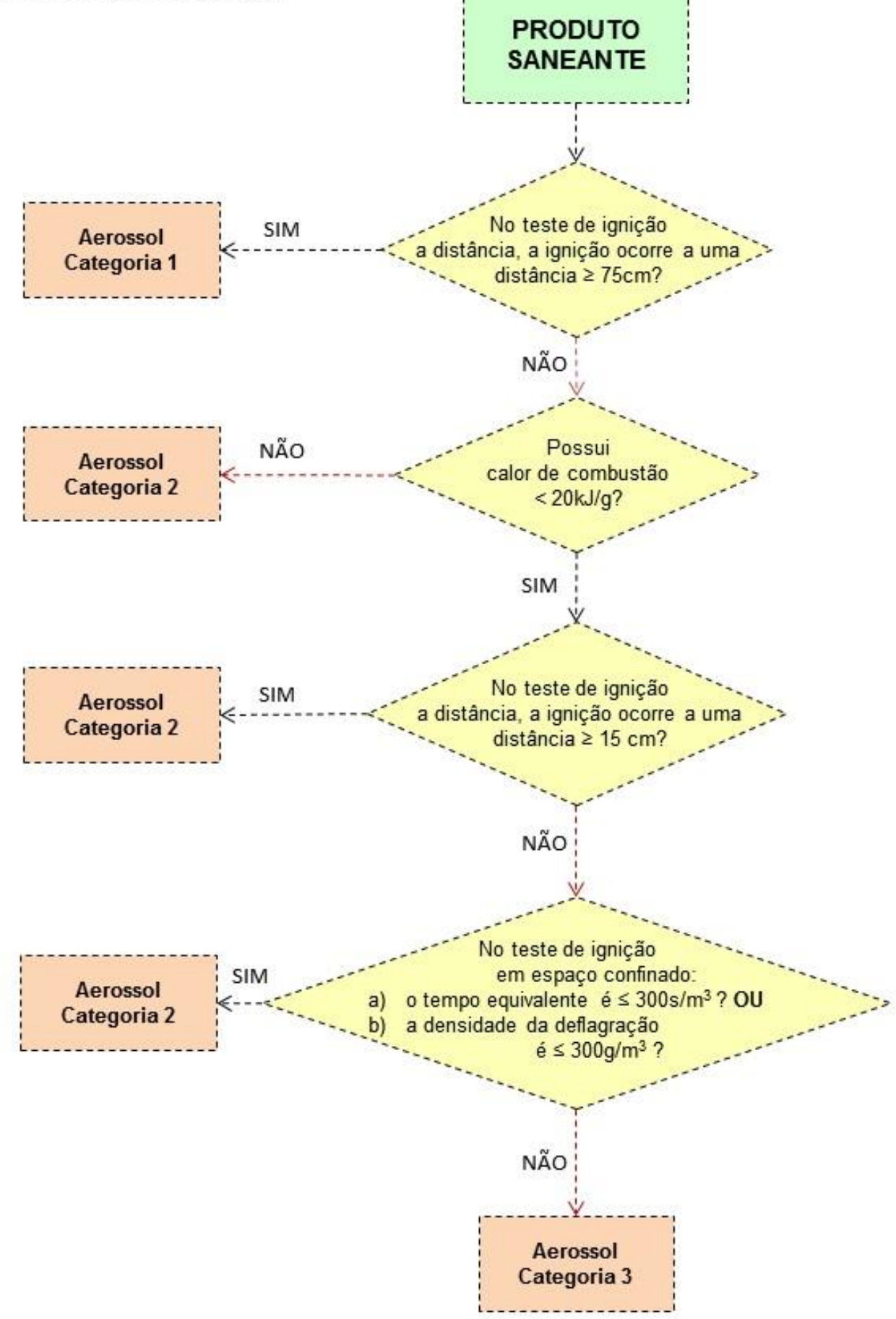

Fluxograma 7 - Decisão lógica para classificação de aerossóis em forma de spray 


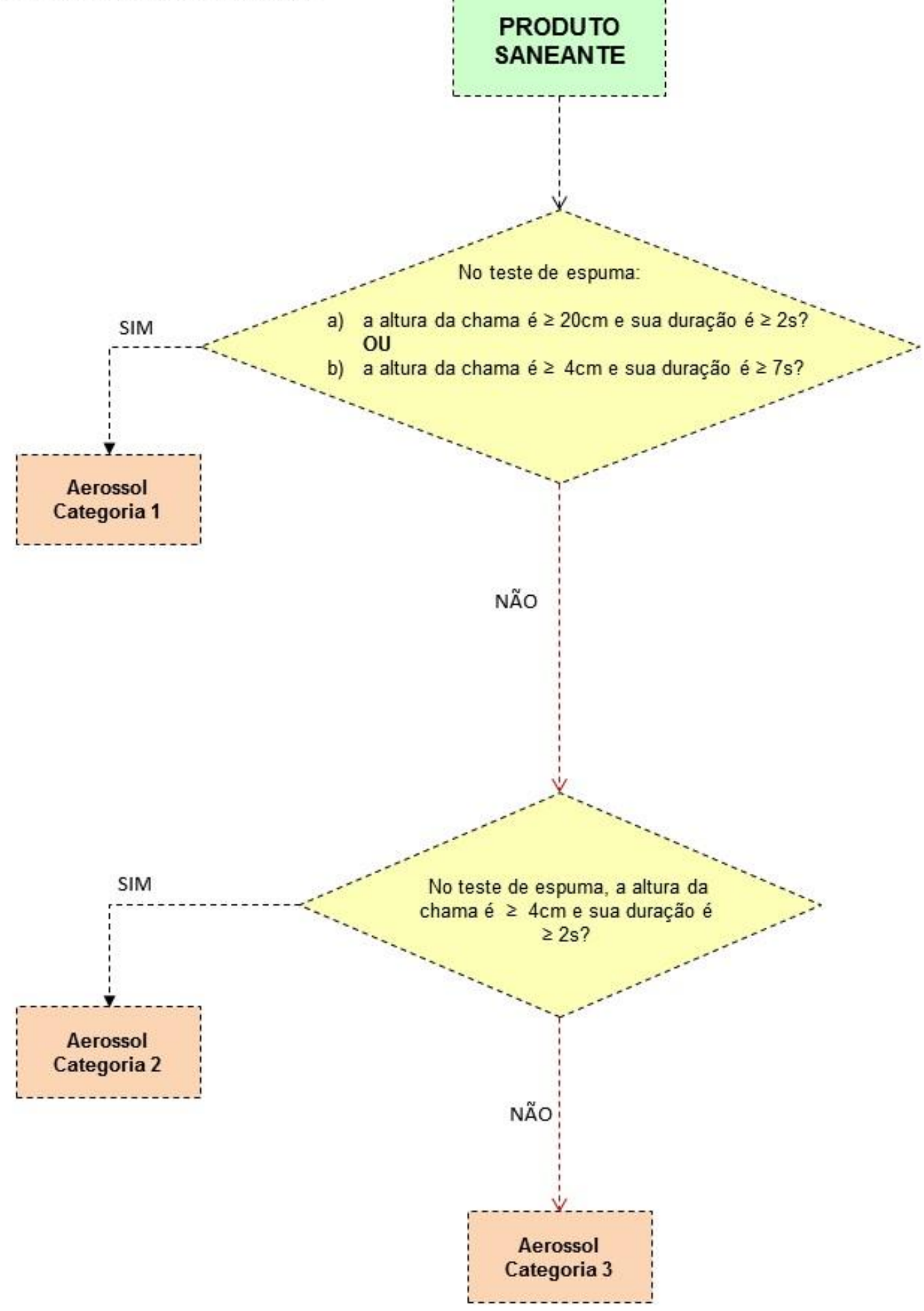

Fluxograma 8 - Decisão lógica para classificação de aerossóis em forma de espuma 


\subsection{Perigos à Saúde}

\subsubsection{Toxicidade Aguda (Oral, Dérmica e Inalatória)}

Segundo o GHS (2015), toxicidade aguda se refere aos efeitos adversos seguidos de uma exposição oral ou dérmica de uma única dose ou doses múltiplas administradas em 24 horas ou de uma exposição inalatória de 4 horas. Para se determinar a toxicidade aguda através de ensaios toxicológicos em mamíferos, analisa-se o valor de DL50 (exposições oral e dérmica) ou CL50 (exposição inalatória) das substancias ou, quando mistura, faz-se um cálculo para determinar o seu valor de ETA (estimativa de toxicidade aguda).

Entende-se por DL50, ou, Dose Letal 50, uma única dose da substância teste que, quando administrada por via oral ou dérmica, causa a morte de $50 \%$ dos animais testados (ANVISA, RDC 59). A unidade para DL50 é mg/l de peso corpóreo do animal ensaiado.

Para a via inalatória, como a porção administrada se refere a uma concentração da substância ou mistura na atmosfera, utiliza-se CL50, ou, Concentração Letal 50, expressos em mg/l ou ppmV (para gases). É importante destacar que a classificação toxicológica aguda inalatória de acordo aos critérios do GHS faz a distinção pela forma física da substância, seja esse gás, vapor, poeira ou névoa (TANAKA, 2013).

Apesar de dados disponíveis para a mistura como um todo serem mais confiáveis e, portanto, serem tidos como prioridade para classificação de perigo, o GHS, reconhecendo a necessidade de proteger o bem-estar dos animais, defende a ideia de que ensaios com animais devem ser evitados quando há informações suficientes de uma mistura similar ou dos ingregientes da mistura.

Para classificar uma mistura para Toxicidade Aguda as 3 vias de exposição devem ser consideradas separadamente e, então, seguem-se as seguintes etapas, prioritariamente na ordem abaixo:

a) Dados de DL50 e CL50 para a mistura como um todo. É importante salientar aqui que, uma vez que a RDC 59 da Anvisa estabelece limites máximos permitidos de DL50 Oral em produtos saneantes, pelo menos para a via Oral, 
é esperado que muitos produtos desse setor possuam os valores dos testes realizados em laboratórios. Esses resultados devem ser usados nesses casos.

b) Pincípios de extrapolação. Esses princípios consideram fatores, tais como: diluição da mistura, lotes do produto, concentração de misturas altamente tóxicas, interpolação dentro de uma mesma categoria de toxicidade para três misturas, misturas substancialmente similares e misturas em forma de aerossóis (ver item 3.1.3.5 do GHS).

c) Fórmula de aditividade usando dados dos ingredientes: A ETA da mistura é determinada usando dados de todos os ingredientes relevantes, de acordo com a equação abaixo para toxicidade aguda:

$$
\frac{100}{E T A_{m}}=\sum_{n} \frac{C_{i}}{E T A_{i}}
$$

em que:

Equacão 1a - Cálculo da Toxicidade Aguda da Mistura (ETAm) quando há dados para todos os ingredientes

- $\quad C_{i}$ é a concentração do ingrediente $\mathrm{i} ;$

- $n$ é o número de ingredientes, variando i de 1 a n;

- $E T A_{i}$ é a estimativa de toxicidade aguda do ingred--iente i (ou seja, o valor de sua DL ou CL50);

- ET $A_{\text {mix }}$ é a estimativa de toxicidade aguda da mistura m.

Nos casos em que não há dados de DL ou CL50 disponíveis para os ingredientes, mas há informação sobre a categoria de Toxicidade Aguda, pode-se estimar o valor da DL ou CL50 de acordo com o previsso na tabela abaixo:

\begin{tabular}{|c|c|c|}
\hline $\begin{array}{c}\text { Categorias de classificação ou faixas de toxicidade } \\
\text { aguda obtidas experimentalmente }\end{array}$ & $\begin{array}{c}\text { Pontos estimados } \\
\text { da conversão da } \\
\text { toxicidade aguda }\end{array}$ & Unidade \\
\hline Toxicidade Aguda Oral - Categoria 1 & 0,5 & mg/kg de \\
peso corpó- \\
reo
\end{tabular}




\begin{tabular}{|c|c|c|}
\hline Toxicidade Aguda Oral - Categoria 5 & 2500 & \\
\hline Toxicidade Aguda Dérmica - Categoria 1 & 5 & \multirow{5}{*}{$\begin{array}{l}\mathrm{mg} / \mathrm{kg} \text { de } \\
\text { peso corpó- } \\
\text { reo }\end{array}$} \\
\hline Toxicidade Aguda Dérmica - Categoria 2 & 50 & \\
\hline Toxicidade Aguda Dérmica - Categoria 3 & 300 & \\
\hline Toxicidade Aguda Dérmica - Categoria 4 & 1100 & \\
\hline Toxicidade Aguda Dérmica - Categoria 5 & 2500 & \\
\hline Toxicidade Aguda Inalatória (gases) - Categoria 1 & 10 & \multirow{4}{*}{ ppmV } \\
\hline Toxicidade Aguda Inalatória (gases) - Categoria 2 & 100 & \\
\hline Toxicidade Aguda Inalatória (gases) - Categoria 3 & 700 & \\
\hline Toxicidade Aguda Inalatória (gases) - Categoria 4 & 4500 & \\
\hline Toxicidade Aguda Inalatória (vapores) - Categoria 1 & 0,05 & \multirow{4}{*}{$\mathrm{mg} / \mathrm{L}$} \\
\hline Toxicidade Aguda Inalatória (vapores) - Categoria 2 & 0,5 & \\
\hline Toxicidade Aguda Inalatória (vapores) - Categoria 3 & 3 & \\
\hline Toxicidade Aguda Inalatória (vapores) - Categoria 4 & 11 & \\
\hline Toxicidade Aguda Inalatória (poeiras/névoas) - Categoria 1 & 0,005 & \multirow{4}{*}{$\mathrm{mg} / \mathrm{L}$} \\
\hline Toxicidade Aguda Inalatória (poeiras/névoas) - Categoria 2 & 0,05 & \\
\hline Toxicidade Aguda Inalatória (poeiras/névoas) - Categoria 3 & 0,5 & \\
\hline Toxicidade Aguda Inalatória (poeiras/névoas) - Categoria 4 & 1,5 & \\
\hline
\end{tabular}

Tabela 2 - Valores estimados da conversão de toxicidade aguda.

Para maiores detalhes da aplicação da fórmula, consultar item 3.1.3.6 do GHS.

\subsubsection{Toxicidade Aguda Oral}

Para produtos saneantes, a Anvisa (RDC 59) estabelece limites de DL50 Oral para produtos sólidos (mínimo $500 \mathrm{mg} / \mathrm{kg}$ de peso corpóreo) e líquidos (mínimo 2000 $\mathrm{mg} / \mathrm{kg}$ de peso corpóreo).

A decisão lógica para classificação de toxicidade aguda oral para líquidos e sólidos está representada nos Fluxogramas $7 \mathrm{a}$ e $7 \mathrm{~b}$ respectivamente. Os estados físicos foram considerados separadamente uma vez que a Anvisa estabelece limites diferentes para os dois estados físicos. 


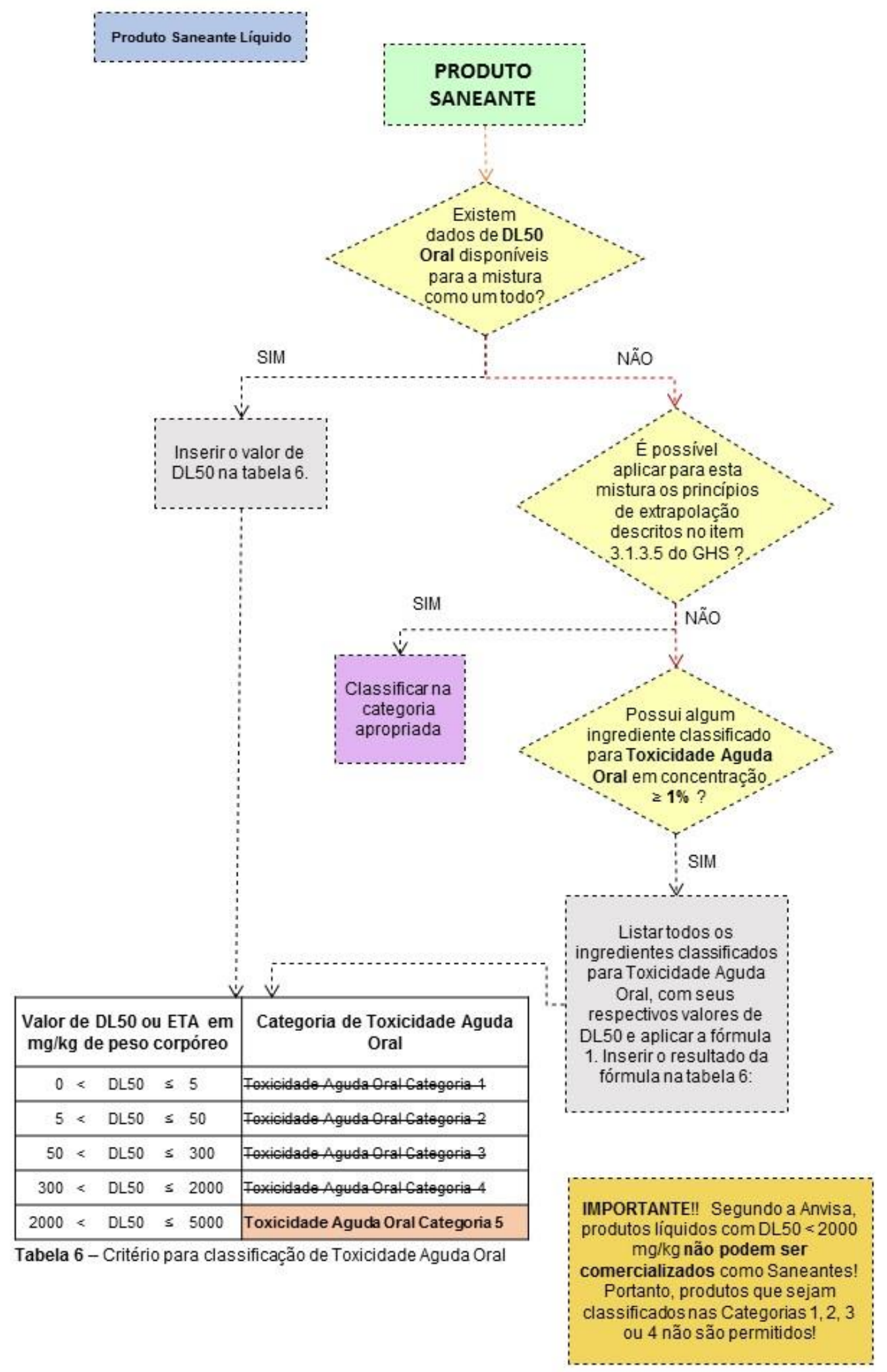

Fluxograma 9 - Decisão lógica para classificação de toxicidade aguda oral em saneantes líquidos 


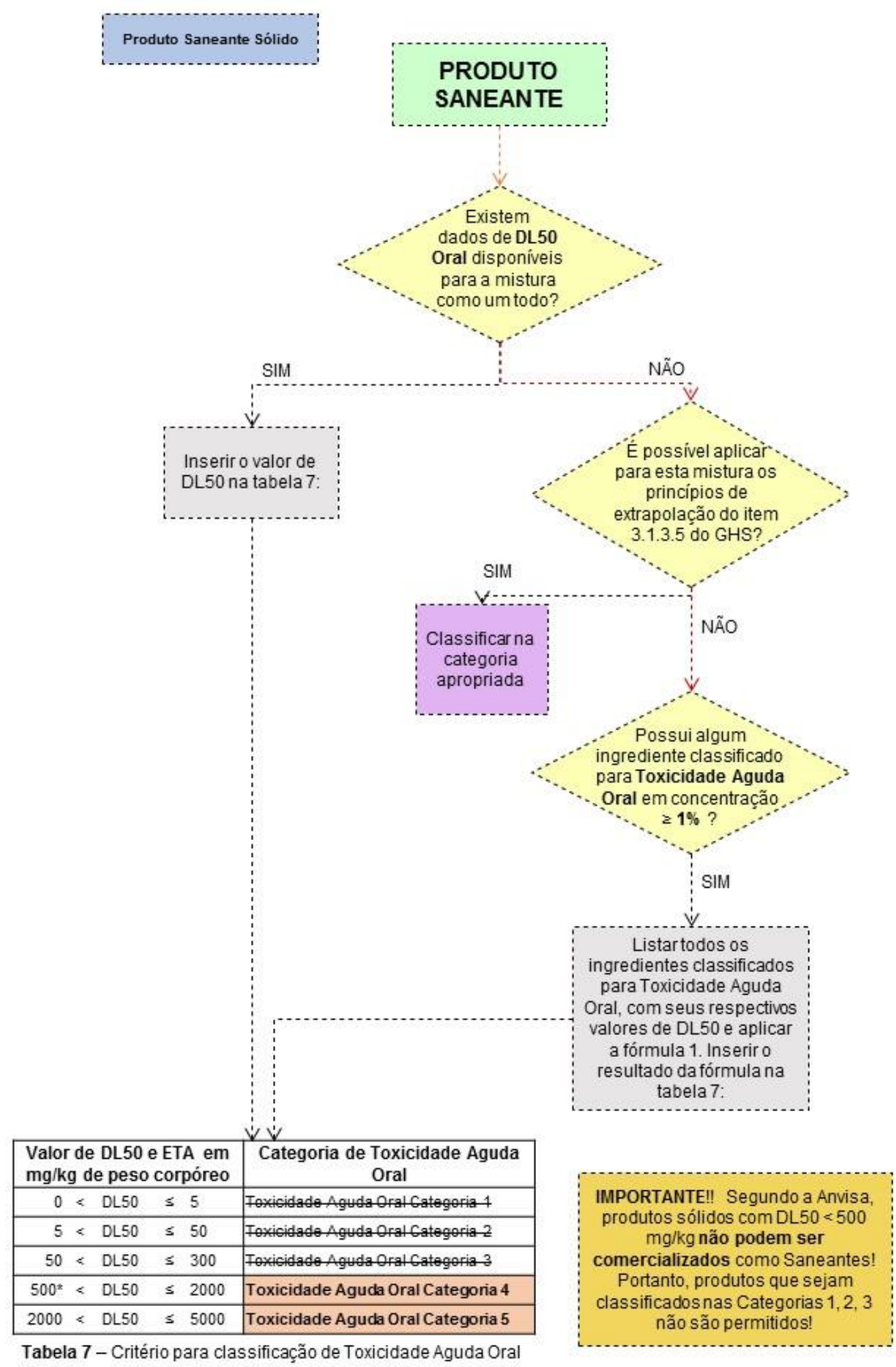

Fluxograma 10 - Decisão lógica para classificação de toxicidade aguda oral em saneantes sólidos 


\subsubsection{Toxicidade Aguda Dérmica}

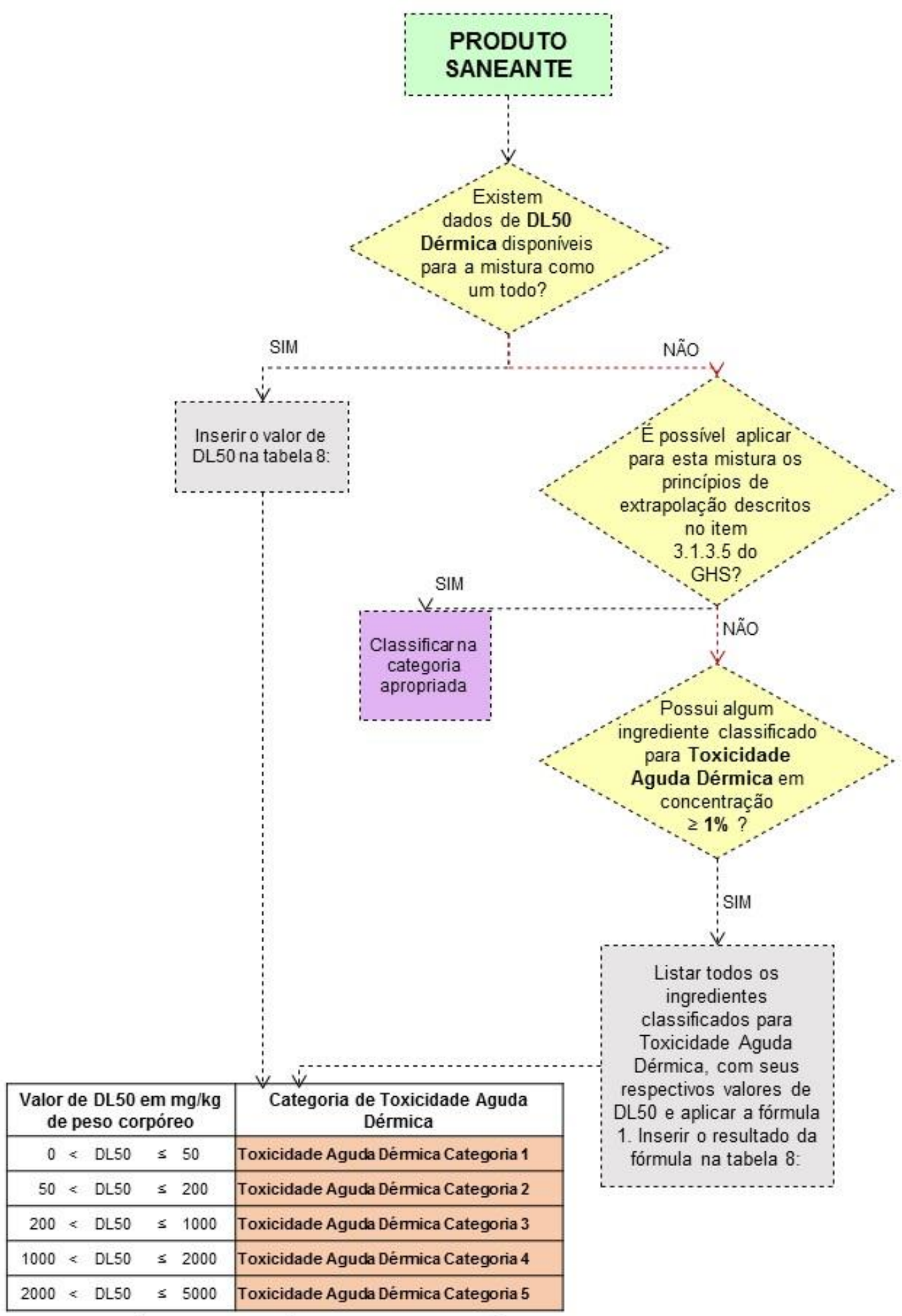

Tabela 8 - Critério para classificação de Toxicidade Aguda Dérmica

Fluxograma 11 - Decisão lógica para classificação de toxicidade aguda dérmica 


\subsubsection{Toxicidade Aguda Inalatória}

A toxicidade Aguda Inalatória é analisada somente em casos em que há compostos voláteis na mistura ou se no uso previsso do produto formar contaminantes atmosféricos.

Os valores de corte para toxicidade por inalação baseiam-se em ensaio de exposição de 4 h. Caso estejam disponíveis somente dados de toxicidade por inalação gerados em períodos de exposição de 1 h, o valor de CL50 deve ser dividido por um fator: de 2 para gases e vapores e de 4 para poeiras e névoas.

A análise da toxicidade aguda inalatória vai depender do tipo de partícula que o produto vai liberar, sendo estas poeiras, névoas, vapores ou gases. Os fluxogramas seguintes analisam cada um dos casos separadamente, uma vez que os valores de CL50 são diferentes devido ao tipo da partícula liberada. 


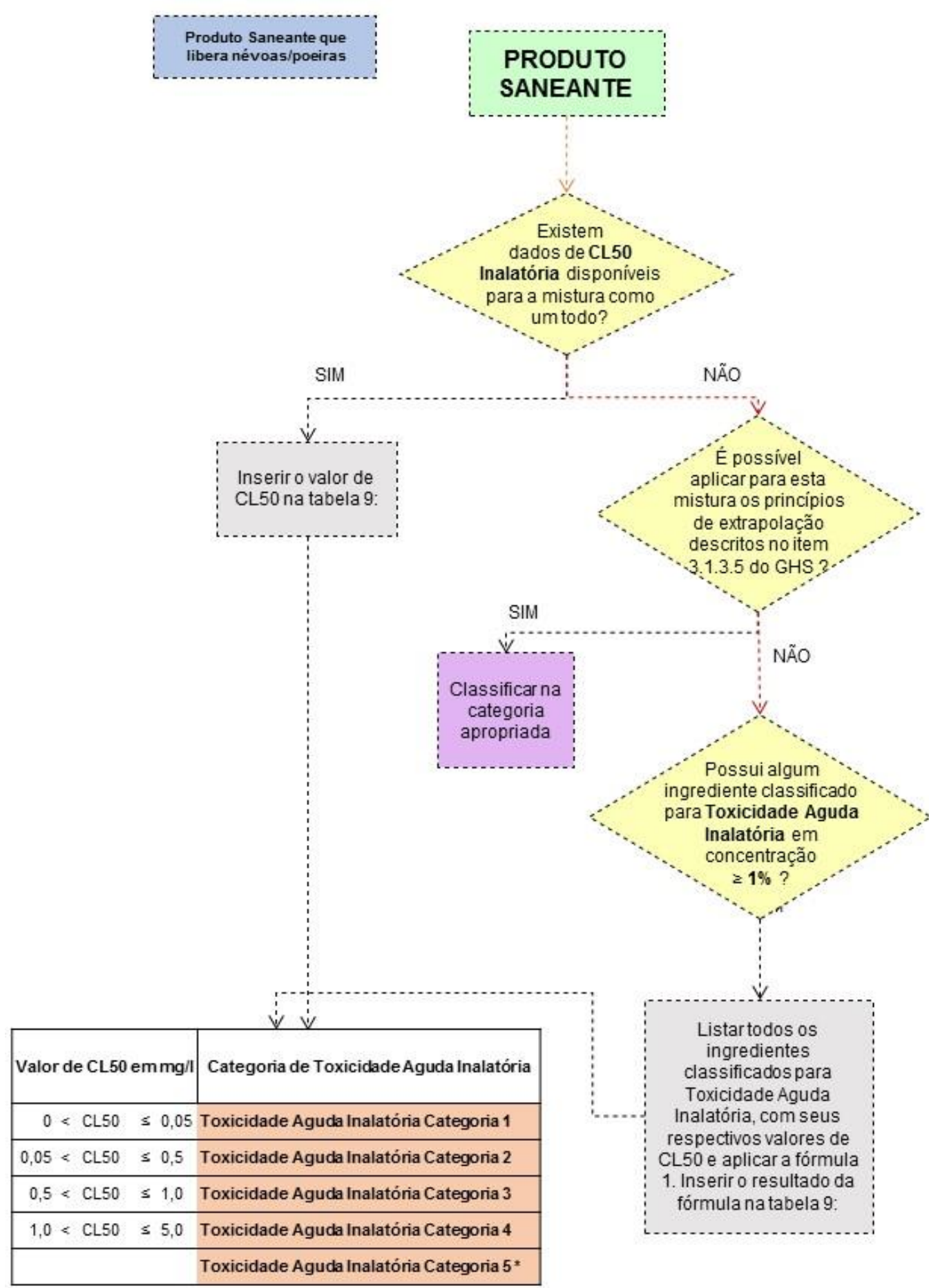

Tabela 9 - Critério para classificação de Toxicidade Aguda Inalatória

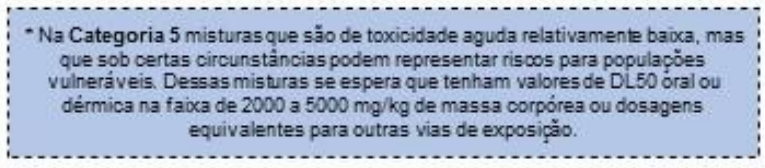

Fluxograma 12 - Decisão lógica para classificação de toxicidade aguda inalatória para produto que liberam névoas e poeiras 


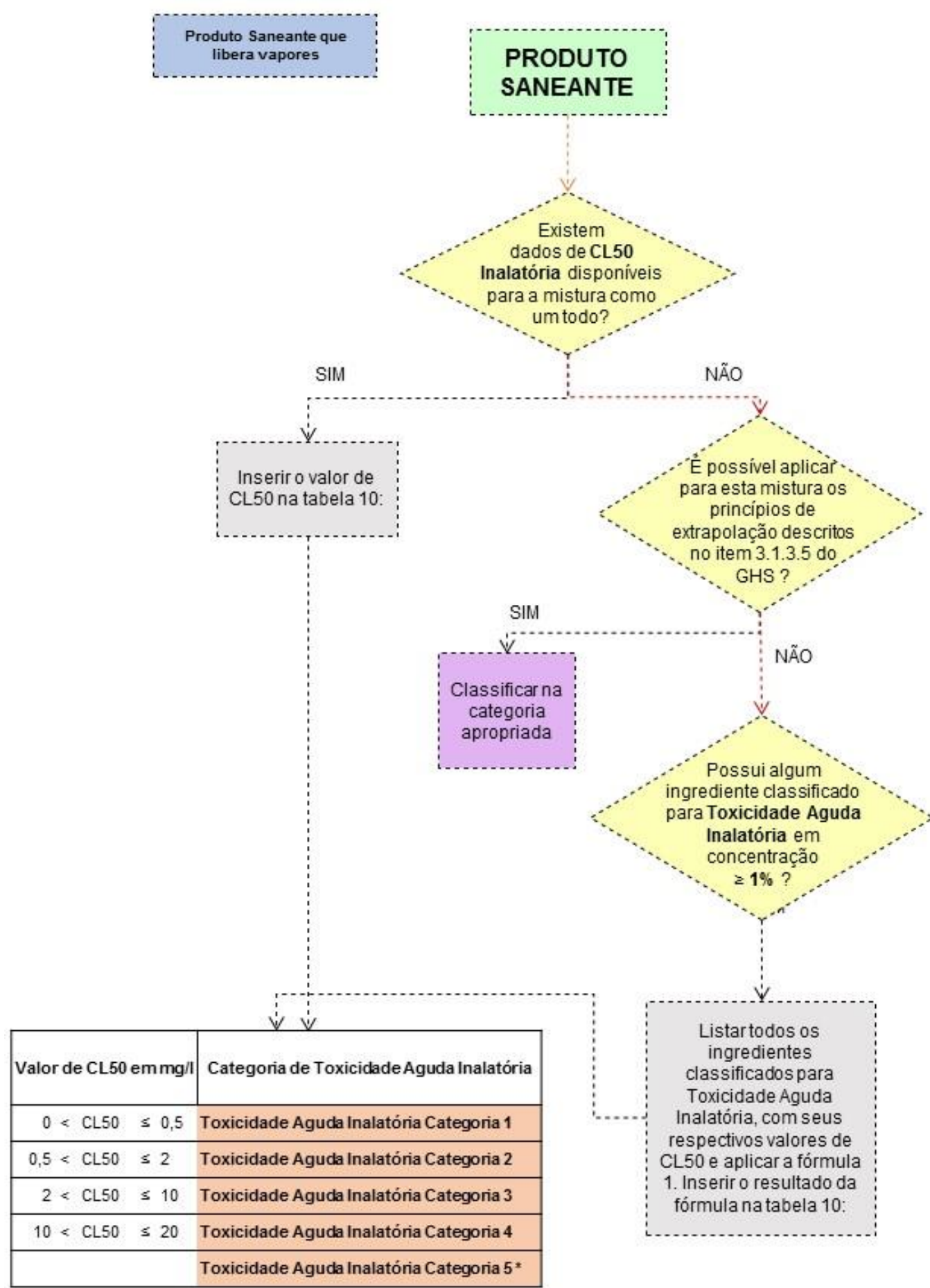

Tabela 10 - Critério para classificação de Toxicidade Aguda Inalatória

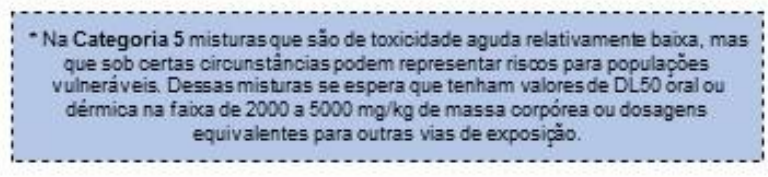

Fluxograma 13 - Decisão lógica para classificação de toxicidade aguda inalatória para produto que liberam vapores 


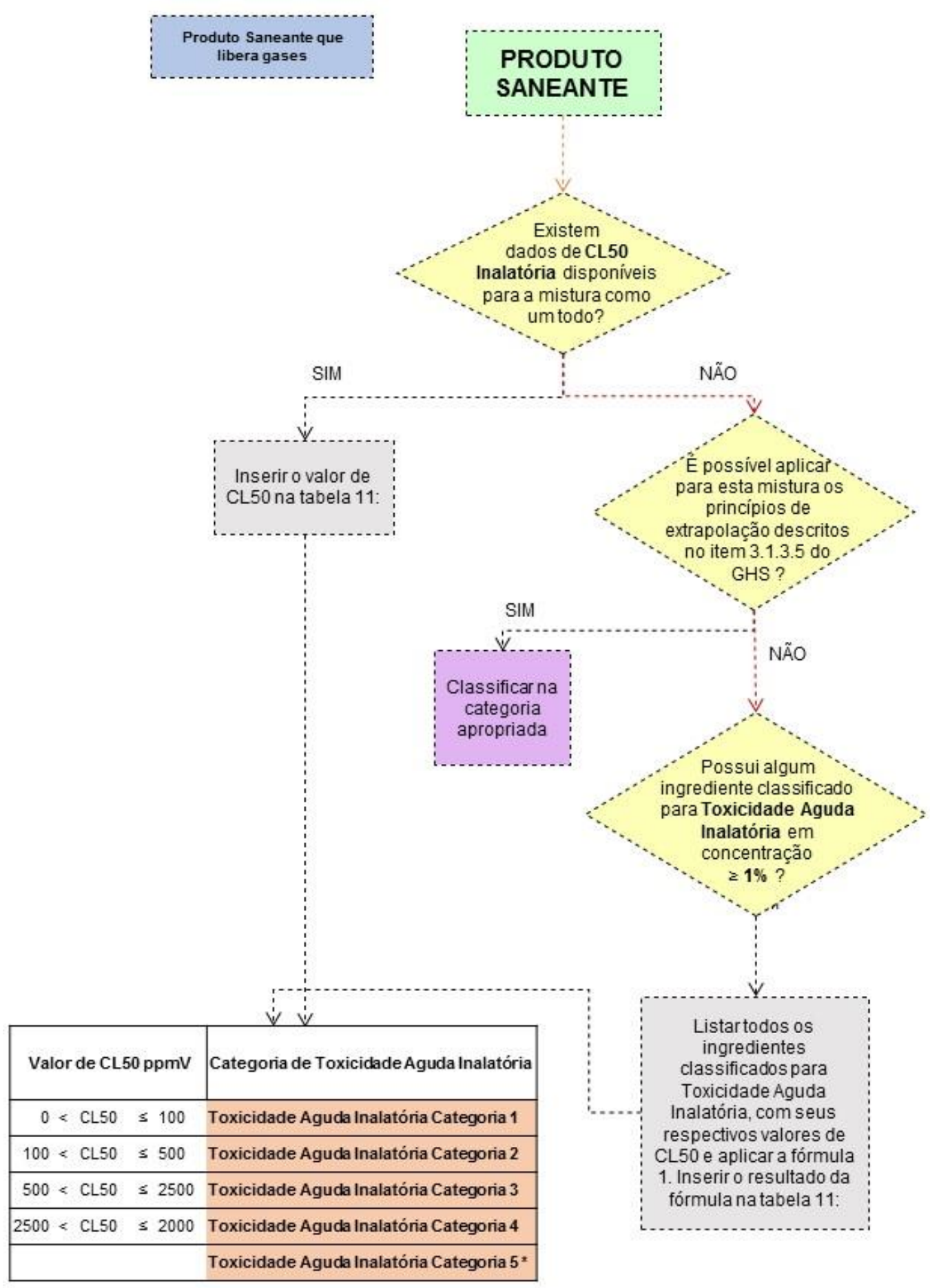

Tabela 11 - Critério para classificação de Toxicidade Aguda Inalatória

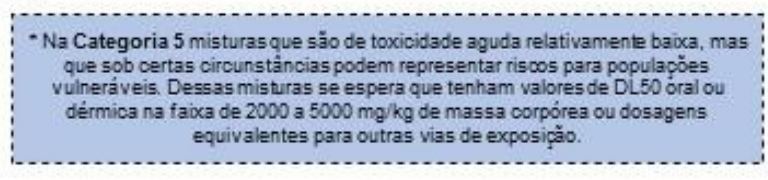

Fluxograma 14 - Decisão lógica para classificação de toxicidade aguda inalatória para produto que liberam gases 


\subsubsection{Corrosão/Irritação à pele}

Dentro desta classe de perigo, um produto pode ser classificado como corrosivo (Categorias 1르 $1 \mathrm{~B}$ e 1C) ou como Irritante (Categorias 2 e 3).

Corrosão à pele é a occorência de um dano irreversível à pele, como necrose visível através da epiderme e na derme, como consequência da aplicação de uma substância de ensaio por um período de até 4 horas. As reações corrosivas são caracterizadas por úlceras, sangramentos e escaras.

Irritação à pele é a produção de uma lesão reversível à pele como consequência da aplicação de um substância por um período de até 4 horas.

Para classificar uma substância nessa categoria, deve ser dada ênfase para evidências em humanos, se existentes, seguidos por dados em animais, dados in vitro e, por fim, outras fontes de informação, como por exemplo modelagem computacional.

Já para classificação de uma mistura, a relevância das informações é a mesma do que para uma substância pura, utilizando inicialmente, os dados da mistura como um todo. Na ausência de informações, uma mistura é considerada corrosiva (Categoria 1) se tiver um $\mathrm{pH} \leq 2$ ou $\geq 11,5$, especialmente quando associado a significantes reservas ácidas/alcalinas. Geralmente espera-se que estas substâncias possam produzir efeitos significantes na pele. Porém, se a avaliação da capacidade de tamponamento indicar que a mistura pode não ser corrosiva, apesar do valor de pH extremo, essa informação precisa ser confirmada por outros dados, preferencialmente por dados de ensaios in vitro.

\subsubsection{Princípios de extrapolação}

Quando a mistura como um todo não foi testada para determinar seu potencial de corrosão/irritação à pele, mas há dados suficientes sobre os ingredientes individuais e misturas similares testadas para caracterizar adequadamente os perigos da mistura, esses dados podem ser usados de acordo com os princípios de extrapolação descritos abaixo.

\section{Diluição}


Se a mistura teste for diluída com um diluente que tenha a mesma classificação de corrosão/irritação ou classificação inferior à do ingrediente original e do qual não seja esperado efeitos sobre a corrosão/irritação à pele nos outros ingredientes, então a mistura diluída deve ser classificada como equivalente à mistura teste original.

\section{Lote}

O potencial de corrosão/irritação à pele de um lote de produção de uma mistura pode ser assumido como substancialmente equivalente àquele de um outro lote de produção do mesmo produto comercial, quando produzido pelo mesmo fabricante ou sob seu controle, a menos que haja razão para acreditar que há variação significativa, de modo que a corrosão/irritação à pele do lote tenha mudado. Se isso ocorrer, é necessária uma nova classificação.

\section{Concentração de misturas da categoria mais elevada de corrosão/irritação à pele}

Quando a mistura teste classificada na categoria mais elevada de corrosão à pele é submetida a uma concentração maior de ingredientes, a nova mistura, mais concentrada deve ser classificada na subcategoria mais alta de corrosão à pele sem a necessidade de testes adicionais Quando a mistura teste classificada como irritante a pele (Categoria 2) é submetida a uma concentração maior de ingredientes, a nova mistura, mais concentrada deve ser classificada pra irritação à pele (Categoria 2) sema necessidade de testes adicionais.

\section{Interpolação dentro de uma categoria de perigo}

Para três misturas ( $A, B$ e $C$ ) com ingredientes idênticos, em que as misturas $A$ e B tenham sido ensaiadas e estejam na mesma categoria de perigo para corrosão/ irritação à pele, e a mistura $\mathrm{C}$ não testada tenha os mesmos ingredientes toxicologicamente ativos que as misturas $A$ e $B$ em concentrações similares, então assume-se que a mistura $C$ esteja na mesma categoria que $A$ e $B$.

\section{Misturas substancialmente similares}

Considerando-se o seguinte:

a) duas misturas: 
(i) $\mathrm{A}+\mathrm{B}$;

(ii) $\mathrm{C}+\mathrm{B}$;

b) a concentração do ingrediente B é essencialmente a mesma nas duas misturas;

c) a concentração do ingrediente $A$ na mistura (i) é igual à do ingrediente $C$ na mistura (ii);

d) os dados de corrosão/irritação à pele para $\mathrm{A}$ e $\mathrm{C}$ estão disponíveis e são substancialmente equivalentes, isso é, estão na mesma categoria de perigo e não é esperado que afetem o potencial de corrosão/irritação à pele de $\mathrm{B}$;

Se a mistura (i) ou (ii) já foi classificada por meio de ensaios, então a outra mistura pode ser classificada na mesma categoria de perigo.

\section{Aerossóis}

Uma mistura em forma de aerossol pode ser classificada na mesma categoria de perigo que uma mistura testada não na forma de aerossol, desde que a adição do propelente não afete as propriedades de corrosão/irritação à pele da mistura quando utilizada na forma de aerossol.

\section{Classificação de misturas quando existem dados disponíveis para todos os ingredientes ou apenas para alguns}

A fim de se fazer uso de todos os dados para classificação de corrosão/irritação à pele disponíveis para uma mistura, as hipóteses seguintes devem ser aplicadas, quando necessário, na abordagem por etapas:

- Os "ingredientes relevantes" de uma mistura são aqueles que estão presentes em concentrações $\geq 1 \%$ (massa/massa para sólidos, líquidos, poeiras, névoas e vapores e volume/volume para gases), a menos que se pressuponha que um ingrediente presente em uma concentração $<1 \%$ ainda seja relevante para classificação de misturas quanto à corrosão/ irritação à pele.

Em geral, a abordagem para classificar misturas como corrosivas/ irritantes à pele quando há dados disponíveis para os ingredientes, mas não para a mistura como um todo, é baseada na teoria da aditividade, na qual cada um dos ingredientes 
que contribui para as propriedades irritantes ou corrosivas da mistura na proporção de sua potencialidade e sua concentração sejam utilizados. Um fator de peso 10 é usado para ingredientes corrosivos quando eles estão presentes em concentração abaixo da concentração limite para classificação na categoria 1, mas estão a uma concentração que contribuirá para classificação da mistura como irritante. A mistura é classificada como corrosiva ou irritante à pele quando a soma das concentrações de cada ingrediente exceder o valor de corte/limite de concentração (tabela 12 do fluxograma 10).

De acordo com a Anvisa, os produtos saneantes de Risco I não podem apresentar características de corrosividade e devem possuir $\mathrm{pH}>2$ ou $<11,5$, ou seja, não podem apresentar $\mathrm{pH}$ extremo. $\mathrm{O}$ mesmo não acontece para produtos saneantes de Risco II, que geralmente possuem pH extremo e características de corrosividade.

O setor de saneantes apresenta uma particularidade especial para essa classe de perigo. Muitos ingredientes adicionados na composição de produtos de limpeza são classificados como corrosivos e podem, algumas vezes, ser adicionados em uma concentração maior do que o limite de corte para esse perigo. Porém, muitas das vezes os ingredientes ácidos e básicos adicionados nesses produtos sofrem entre si uma reação de neutralização, gerando como produto um componente neutro, não corrosivo. E, como já foi descrito anteriormente, de acordo com o GHS, uma mistura é uma combinação ou uma solução de duas ou mais substâncias que não reagem entre si. Porém, nesses casos, o componente que deve ser levado em conta para realizar a teoria da aditividade é o produto da reação de neutralização.

Para informações mais detalhadas de classificação para Corrosão/lrritação à pele, consultar o capítulo 3.2 do GHS.

O Fluxograma 15 apresenta os passos para classificação de uma mistura em Corrosão/Irritação à pele e a tabela 12 desse fluxograma apresenta a teoria da aditividade para classificação da mistura com base em seus ingredientes classificados para essa classe de perigo, utilizando sua classificação e sua composição na mistura. 


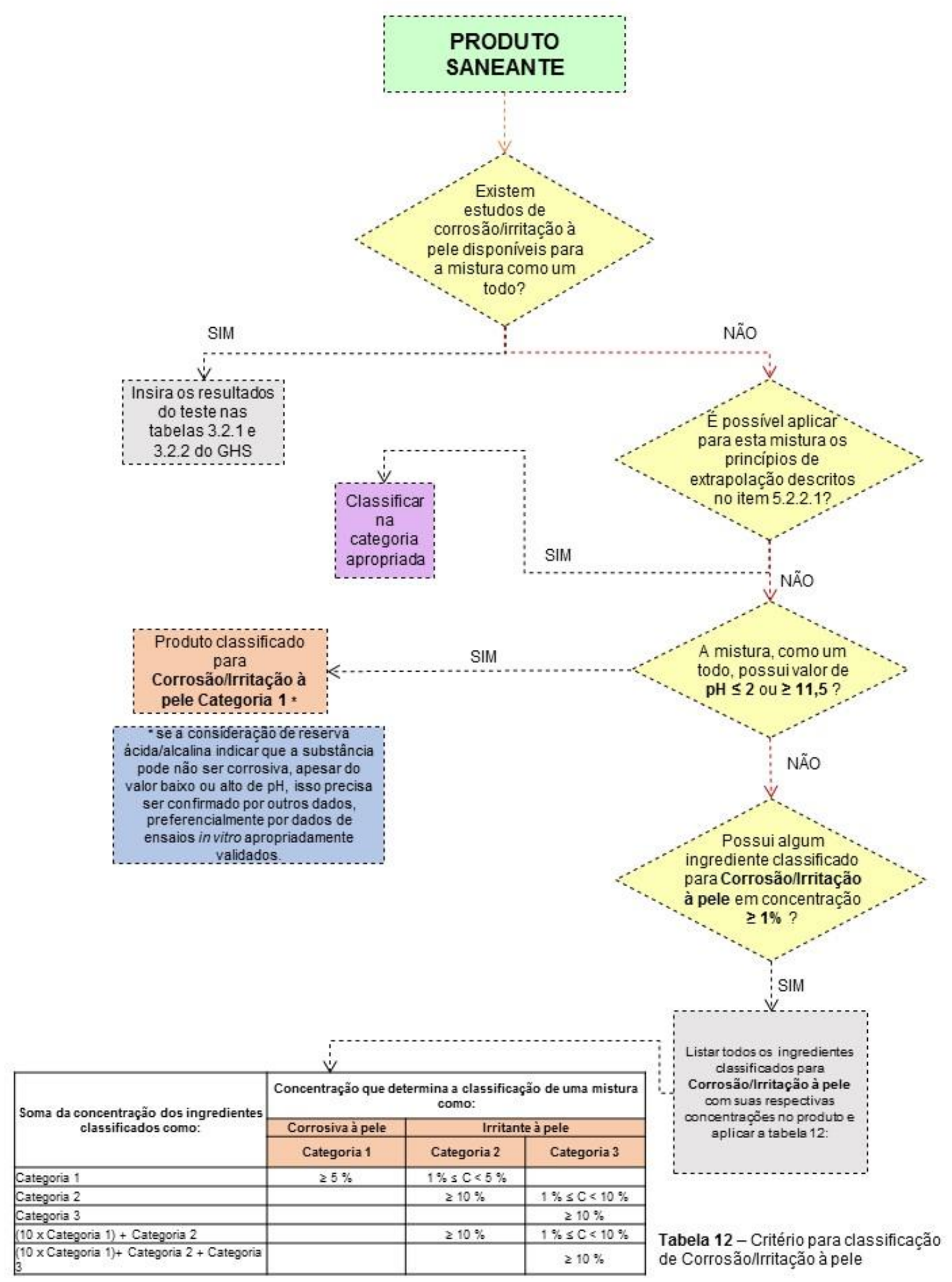

\section{Fluxograma 15 - Decisão lógica para classificação corrosão/irritação a pele}




\subsubsection{Lesões oculares graves/irritação ocular}

Dentro desta classe de perigo, um produto podeser classificado como potencial para causar lesão ocular grave (Categoria 1) ou irritação (Categoria2).

Lesão ocular grave consiste na ocorrência de danos no tecido ocular ou degradação grave da visão, resultantes da aplicação da substância de ensaio na superfície dos olhos e esses danos não são completamente reversíveis em um período de 1 dias depois da aplicação.

A irritação ocular consiste em alterações nos olhos resultantes da aplicação da substância de ensaio na superfície dos olhos e esses danos são completamente reversíveis no período de 21 dias depois da aplicação.

Para classificar uma substância nessa categoria, deve ser dada ênfase para evidências em humanos, se existentes, seguidos por dados em animais, dados in vitro e, por fim, outras fontes de informação, como por exemplo modelagem computacional.

Já para classificação de uma mistura, a relevância das informações é a mesma do que para uma mistura, utilizando inicialmente, os dados da mistura como um todo. $\mathrm{Na}$ ausência de informações, uma mistura é classificada como potencial causadora de lesões oculares graves (Categoria 1) se tiver um $\mathrm{pH} \leq 2$ ou $\geq 11,5$, especialmente quando associado a significantes reservas ácidas/alcalinas. Geralmente espera-se que estas substâncias possam produzir efeitos significantes nos olhos. Porém, se a avaliação da capacidade de tamponamento indicar que a mistura pode não causar graves lesões oculares, apesar do valor de pH extremo, essa informação precisa ser confirmada por outros dados, preferencialmente por dados de ensaios in vitro.

Como o olho é muito mais sensível do que a pele, quando um produto á classificado para corrosão à pele, automaticamente ele será classificado também como potencial para causar lesões oculares graves. Portanto, para avaliar essa classe de perigo, o perigo de corrosão à pele também é considerado.

\subsubsection{Princípios de extrapolação}


Quando a mistura como um todo não foi testada para determinar seu potencial de causar corrosão à pele, lesões oculares graves ou irritação ocular, mas há dados suficientes sobre os ingredientes individuais e misturas similares testadas para caracterizar adequadamente os perigos da mistura, esses dados podem ser usados de acordo com os princípios de extrapolação descritos abaixo.

\section{Diluição}

Se a mistura teste for diluída com um diluente que tenha a mesma classificação de lesões oculares graves/irritação ocular ou classificação inferior à do ingrediente original e do qual não seja esperado efeitos sobre a lesões oculares graves/irritação ocular nos outros ingredientes, então a mistura diluída deve ser classificada como equivalente à mistura teste original.

\section{Lote}

O potencial de lesões oculares graves/irritação ocular de um lote de produção de uma mistura pode ser assumido como substancialmente equivalente àquele de um outro lote de produção do mesmo produto comercial, quando produzido pelo mesmo fabricante ou sob seu controle, a menos que haja razão para acreditar que há variação significativa, de modo que a lesões oculares graves/irritação ocular do lote tenha mudado. Se isso ocorrer, é necessária uma nova classificação.

\section{Concentração de misturas da categoria mais elevada de danos oculares}

Quando a mistura teste classificada para lesões oculares graves (Categoria 1) é submetida a uma concentração maior de ingredientes, a nova mistura, mais concentrada deve ser classificada para lesões oculares graves (Categoria 1) sem a necessidade de testes adicionais Quando a mistura teste classificada como irritante ocular (Categoria 2 ou 2A) é submetida a uma concentração maior de ingredientes, a nova mistura, mais concentrada deve ser classificada pra irritação ocular (Categoria 2 ou 2A) sem a necessidade de testes adicionais.

\section{Interpolação dentro de uma categoria de perigo}

Para três misturas ( $A, B$ e $C$ ) com ingredientes idênticos, em que as misturas $A$ e $B$ tenham sido ensaiadas e estejam na mesma categoria de perigo para lesões oculares graves/irritação ocular, e a mistura C não testada tenha os mesmos 
ingredientes toxicologicamente ativos que as misturas $A$ e $B$ em concentrações similares, então assume-se que a mistura $C$ esteja na mesma categoria que $A$ e $B$.

\section{Misturas substancialmente similares}

Considerando-se o seguinte:

a) duas misturas:

(i) $A+B$;

(ii) $\mathrm{C}+\mathrm{B}$;

b) a concentração do ingrediente B é essencialmente a mesma nas duas misturas;

c) a concentração do ingrediente $A$ na mistura (i) é igual à do ingrediente $C$ na mistura (ii);

d) os dados de lesões oculares graves/irritação ocular para A e C estão disponíveis e são substancialmente equivalentes, isso é, estão na mesma categoria de perigo e não é esperado que afetem o potencial de causar lesões oculares graves/irritação ocular de B;

Se a mistura (i) ou (ii) já foi classificada por meio de ensaios, então a outra mistura pode ser classificada na mesma categoria de perigo.

\section{Aerossóis}

Uma mistura em forma de aerossol pode ser classificada na mesma categoria de perigo que uma mistura testada não na forma de aerossol, desde que a adição do propelente não afete as propriedades de causar lesões oculares graves/irritação ocular da mistura quando utilizada na forma de aerossol.

Classificação de misturas quando existem dados disponíveis para todos os ingredientes ou apenas para alguns

A fim de se fazer uso de todos os dados para classificação de lesões oculares graves/irritação ocular disponíveis para uma mistura, as hipóteses seguintes devem ser aplicadas, quando necessário, na abordagem por etapas: 
- Os "ingredientes relevantes" de uma mistura são aqueles que estão presentes em concentrações $\geq 1 \%$ (massa/massa para sólidos, líquidos, poeiras, névoas e vapores e volume/volume para gases), a menos que se pressuponha que um ingrediente presente em uma concentração < $1 \%$ ainda seja relevante para classificação de misturas quanto à lesões oculares graves/irritação ocular.

Em geral, a abordagem para classificar misturas como potencial em provocar lesões oculares graves/irritação ocular quando há dados disponíveis para os ingredientes, mas não para a mistura como um todo, é baseada na teoria da aditividade, na qual cada um dos ingredientes corrosivos ou que causem lesões oculares graves/irritação ocular sejam utilizados na proporção de sua potencialidade e sua concentração. Um fator de peso 10 é usado para ingredientes corrosivos ou que causem lesões oculares graves/irritaçãoquando eles estão presentes em concentração abaixo da concentração limite para classificação na categoria 1, mas estão a uma concentração que contribuirá para classificação da mistura. A mistura é classificada para lesões oculares graves/irritação ocular quando a soma das concentrações de cada ingrediente exceder o valor de corte/limite de concentração (tabela 13 do fluxograma 16).

Para informações mais detalhadas de classificação para Lesões oculares graves/irritação ocular, consultar o capítulo 3.3 do GHS.

O Fluxograma 16 apresenta os passos para classificação de uma mistura em Lesões oculares graves/irritação ocular e a tabela 13 desse fluxograma apresenta a teoria da aditividade para classificação da mistura com base em seus ingredientes classificados para essa classe de perigo, utilizando sua classificação e sua composição na mistura. 


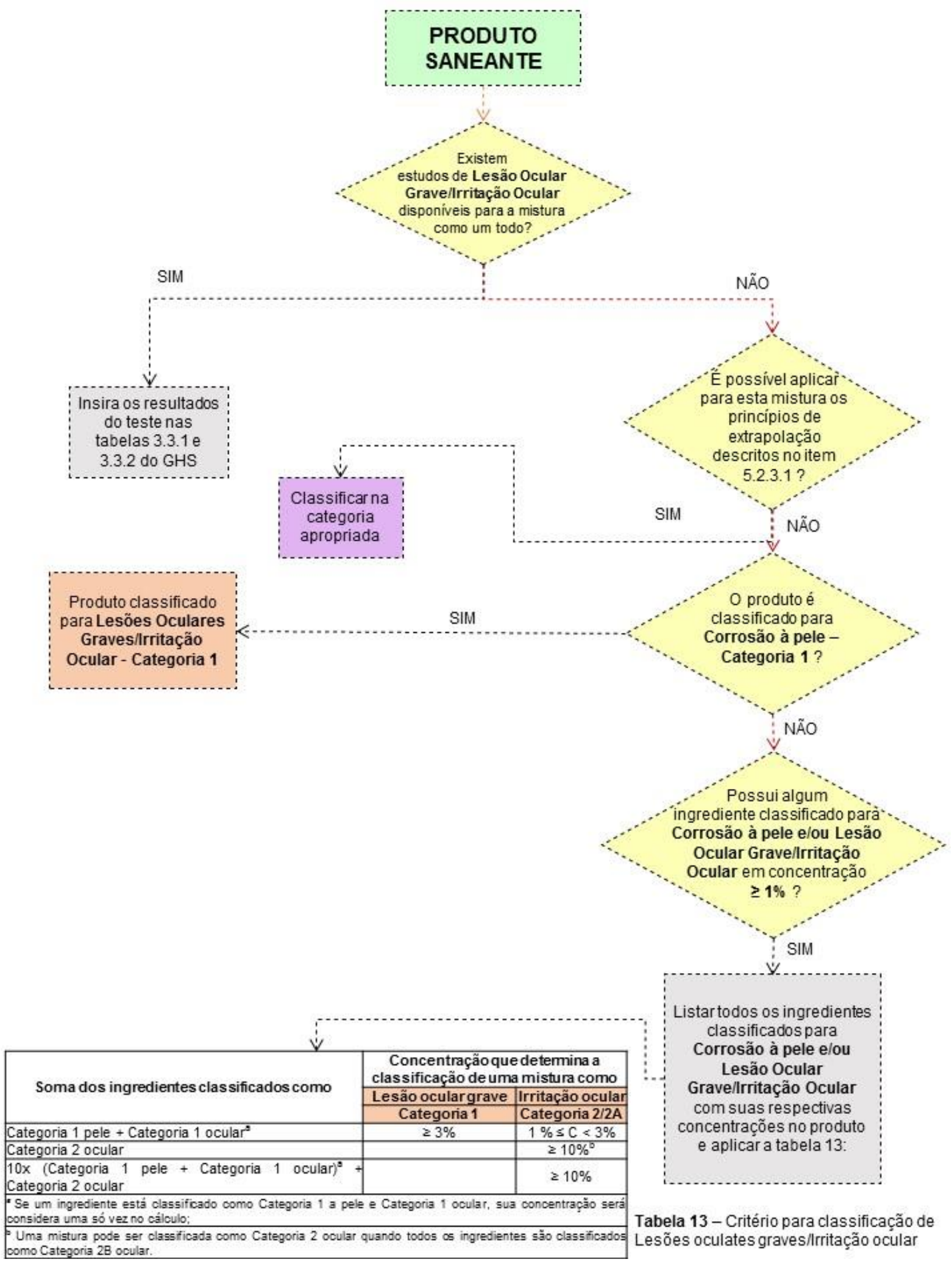

Fluxograma 16 - Decisão lógica para classificação de lesões oculares graves/irritação ocular 


\subsubsection{Sensibilização à pele}

Um sensibilizante à pele é uma substância que pode induzir resposta alergênica quando em contato com a pele. Produtos sensibilizantes à pele podem ser classificados na Categoria $1 \mathrm{e}$, quando houver informação suficiente ou a necessidade de uma avaliação minuciosa, podem ser alocados nas sub-categorias $1 \mathrm{~A}$ ou $1 \mathrm{~B}$.

Podem ser utilizados para classificação nessa classe de perigo as evidências em humanos, como prioridade ou, quando não disponíveis, estudos em animais.

\subsubsection{Princípios de extrapolação}

Quando a mistura como um todo não foi testada para determinar seu potencial de causar sensibilização à pele, mas há dados suficientes sobre os ingredientes individuais e misturas similares testadas para caracterizar adequadamente os perigos da mistura, esses dados podem ser usados de acordo com os princípios de extrapolação descritos abaixo.

\section{Diluição}

Se a mistura teste é diluída com um diluente que não é sensibilizante à pele e que não se espera que afete a sensibilização de outros ingredientes, então a nova mistura diluída pode ser classificada como equivalente a mistura original testada.

\section{Lote}

As propriedades sensibilizantes de um lote de produção de uma mistura podem ser assumidas como substancialmente equivalente àquele de um outro lote de produção do mesmo produto comercial, quando produzido pelo mesmo fabricante ou sob seu controle, a menos que haja razão para acreditar que há variação significativa, de modo que a sensibilização à pele do lote tenha mudado. Se isso ocorrer, é necessária uma nova classificação.

\section{Concentração de misturas da categoria mais elevada de sensibilização à pele}

Quando a mistura teste é classificada como Categoria 1 ou sub-categoria $1 \mathrm{~A} \mathrm{e}$ a concentração dos ingredientes classificados nestas categorias é aumentada, a nova 
mistura deve ser classificada na Categoria 1 ou na sub-categoria $1 \mathrm{~A}$ sem serem necessários testes adicionais.

\section{Interpolação dentro de uma categoria de perigo}

Para três misturas ( $A, B$ e $C)$ com ingredientes idênticos, em que as misturas $A$ e B tenham sido ensaiadas e estejam na mesma categoria de perigo para sensibilização à pele, e a mistura $C$ não testada tenha os mesmos ingredientes toxicologicamente ativos que as misturas $A$ e B em concentrações similares, então assume-se que a mistura $\mathrm{C}$ esteja na mesma categoria que $\mathrm{A}$ e $\mathrm{B}$.

\section{Misturas substancialmente similares}

Considerando-se o seguinte:

a) duas misturas:

(i) $A+B$;

(ii) $\mathrm{C}+\mathrm{B}$;

b) a concentração do ingrediente B é essencialmente a mesma nas duas misturas;

c) a concentração do ingrediente $A$ na mistura (i) é igual à do ingrediente $C$ na mistura (ii);

d) $O$ ingrediente $B$ é um sensibilizante à pele, enquanto os ingredientes $A$ e $C$ não são

e) Não é esperado que os ingredientes A e C afetem as propriedades sensibilizantes de B

Se a mistura (i) ou (ii) já foi classificada por meio de ensaios, então a outra mistura pode ser classificada na mesma categoria de perigo.

\section{Aerossóis}

Uma mistura em forma de aerossol pode ser classificada na mesma categoria de perigo que uma mistura testada não na forma de aerossol, desde que a adição do propelente não afete as propriedades sensibilizantes da mistura quando utilizada na forma de aerossol. 
Classificação de misturas quando existem dados disponíveis para todos os ingredientes ou apenas para alguns

Uma mistura deve ser classificada como sensibilizante à pele quando pelo menos um de seus ingredientes estejam classificados para tais perigos e estejam acima dos valores de limite de corte de acordo com a tabela 14 do fluxograma 17.

Para informações mais detalhadas de classificação para Sensibilização à pele, consultar o capítulo 3.4 do GHS.

O Fluxograma 17 apresenta os passos para classificação de uma mistura em Sensibilização à pele e a tabela 14 desse fluxograma apresenta os limites de corte da composição dos ingredientes para classificação nessa classe de perigo. 


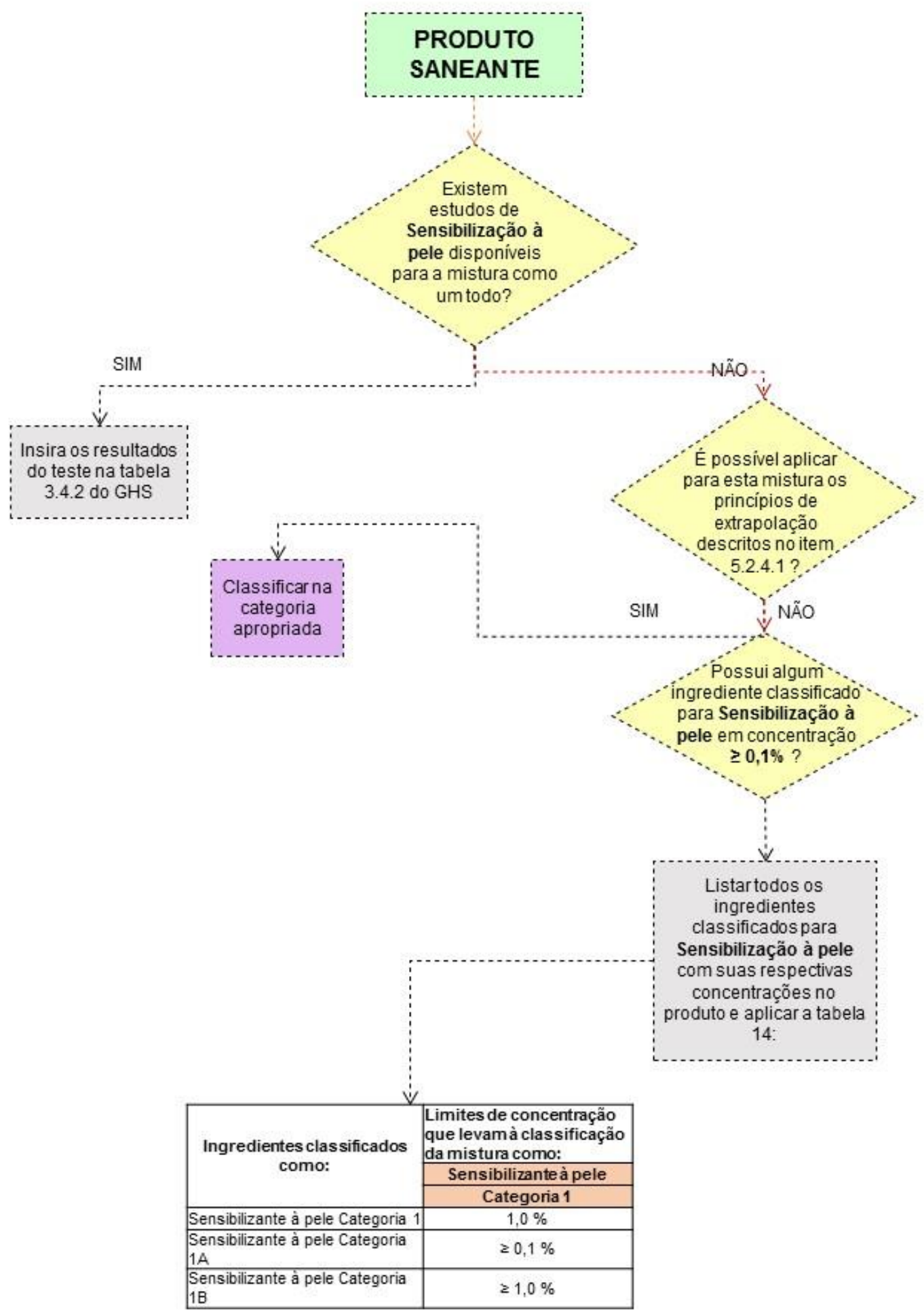

Tabela 14 - Critério para classificação para Sensibiilização à pele

\section{Fluxograma 17 - Decisão lógica para classificação de sensibilização à pele}




\subsubsection{Sensibilização respiratória}

Um sensibilizante respiratório é uma substância cuja inalação induz a hipersensibilidade das vias respiratórias.

Podem ser utilizados para classificação nessa classe de perigo as evidências em humanos, como prioridade ou, quando não disponíveis, estudos em animais.

\subsubsection{Princípios de extrapolação}

Quando a mistura como um todo não foi testada para determinar seu potencial de causar sensibilização respiratória, mas há dados suficientes sobre os ingredientes individuais e misturas similares testadas para caracterizar adequadamente os perigos da mistura, esses dados podem ser usados de acordo com os princípios de extrapolação descritos abaixo.

\section{Diluição}

Se a mistura teste é diluída com um diluente que não é sensibilizante respiratória e que não se espera que afete a sensibilização de outros ingredientes, então a nova mistura diluída pode ser classificada como equivalente a mistura original testada.

\section{Lote}

As propriedades sensibilizantes de um lote de produção de uma mistura podem ser assumidas como substancialmente equivalente àquele de um outro lote de produção do mesmo produto comercial, quando produzido pelo mesmo fabricante ou sob seu controle, a menos que haja razão para acreditar que há variação significativa, de modo que a sensibilização respiratória do lote tenha mudado. Se isso ocorrer, é necessária uma nova classificação.

\section{Concentração de misturas da categoria mais elevada de sensibilização respiratória}

Quando a mistura teste é classificada como Categoria 1 ou sub-categoria $1 \mathrm{~A} \mathrm{e}$ a concentração dos ingredientes classificados nestas categorias é aumentada, a nova 
mistura deve ser classificada na Categoria 1 ou na sub-categoria $1 \mathrm{~A}$ sem serem necessários testes adicionais.

\section{Interpolação dentro de uma categoria de perigo}

Para três misturas ( $A, B$ e $C)$ com ingredientes idênticos, em que as misturas $A$ e B tenham sido ensaiadas e estejam na mesma categoria de perigo para sensibilização respiratória, e a mistura $C$ não testada tenha os mesmos ingredientes toxicologicamente ativos que as misturas $A$ e $B$ em concentrações similares, então assume-se que a mistura $\mathrm{C}$ esteja na mesma categoria que $\mathrm{A}$ e $\mathrm{B}$.

\section{Misturas substancialmente similares}

Considerando-se o seguinte:

a) duas misturas:

(i) $A+B$;

(ii) $\mathrm{C}+\mathrm{B}$;

b) a concentração do ingrediente B é essencialmente a mesma nas duas misturas;

c) a concentração do ingrediente $A$ na mistura (i) é igual à do ingrediente $C$ na mistura (ii);

d) O ingrediente $B$ é um sensibilizante respiratório, enquanto os ingredientes $A$ e $C$ não são

e) Não é esperado que os ingredientes A e C afetem as propriedades sensibilizantes de B

Se a mistura (i) ou (ii) já foi classificada por meio de ensaios, então a outra mistura pode ser classificada na mesma categoria de perigo.

\section{Aerossóis}

Uma mistura em forma de aerossol pode ser classificada na mesma categoria de perigo que uma mistura testada não na forma de aerossol, desde que a adição do propelente não afete as propriedades sensibilizantes da mistura quando utilizada na forma de aerossol. 
Classificação de misturas quando existem dados disponíveis para todos os ingredientes ou apenas para alguns

Uma mistura deve ser classificada como sensibilizante respiratório quando pelo menos um de seus ingredientes estejam classificados para tais perigos e estejam acima dos valores de limite de corte de acordo com a tabela 15 do fluxograma 18.

Para informações mais detalhadas de classificação para Sensibilização respiratória, consultar o capítulo 3.4 do GHS.

O Fluxograma 18 apresenta os passos para classificação de uma mistura em Sensibilização respiraória e a tabela 15 desse fluxograma apresenta os limites de corte da composição dos ingredientes para classificação nessa classe de perigo. 


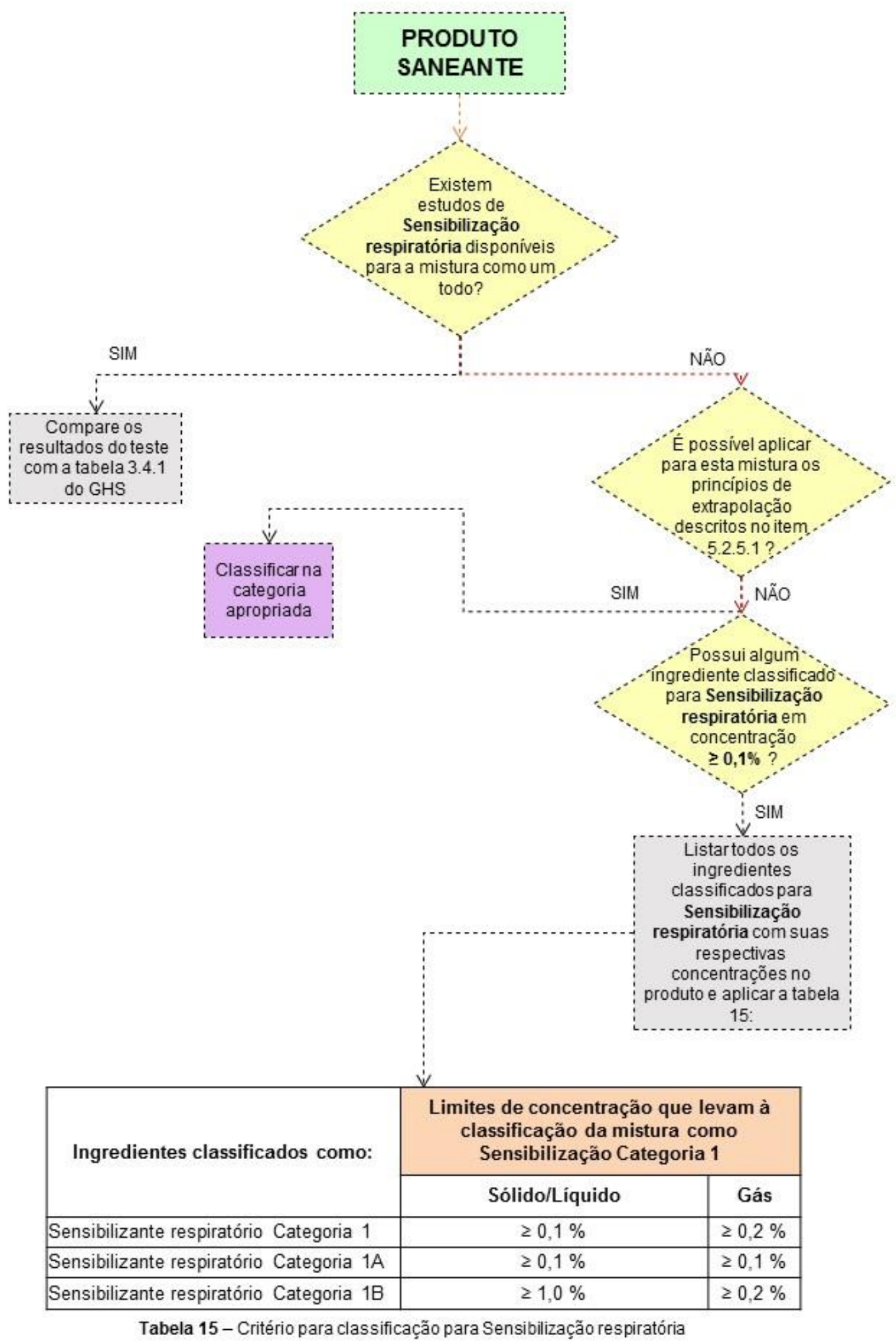

Fluxograma 18 - Decisão lógica para classificação de sensibilização respiratória 


\subsubsection{Mutagenicidade em Células germinativas, Carcinogenicidade e Toxicidade à Reprodução}

A Anvisa determina, no Artigo 9o da RDC 59 que

\footnotetext{
"Art. 9o É proibida a fabricação, importação e a comercialização de produto cuja formulação contenha:

III - componente que apresente efeitos comprovadamente mutagênicos, teratogênicos ou carcinogênicos em mamíferos."
}

Com base no exposto e, analisando as tabelas com os critérios de classificação para Mutagenicidade, Carcinogenicidade e Toxicidade à Reprodução descritos no GHS, conclui-se que, para produtos saneantes, não é permitido classificações na Categoria 1 (incluindo suas respectivas sub-categorias 1A e 1B) para esse setor de produtos.

\subsubsection{Mutagenicidade}

Nesta classe de perigo se enquadram as substâncias que podem provocar mutações em células germinativas de humanos que podem se transmitir por gerações. Entretanto, os ensaios mutagênicos/genotóxicos in vitro e em células somáticas em mamíferos in vivo, também são considerados para classificação nessa classe de perigo.

Um produto mutagênico pode ser classificado como Categoria 1 (subcategorias $1 \mathrm{~A}$ e 1B) e Categoria 2, porém, para produtos saneantes, a Categoria 1, com suas respectivas subcategorias, não é aplicável.

Para classificação de substâncias puras, os critérios estão descritos no capítulo 3.5 do GHS, na figura 3.5.1. Já para classificação de uma mistura, os procedimentos seguem o mesmo princípio da classificação em outras classes de perigo, ou seja, primeiro avaliam-se os estudos realizados para a mistura como um todo, se disponíveis. Se não há, utiliza-se os princípios de extrapolação e, caso não se apliquem, por último, utilizam-se os dados disponíveis para os ingredientes. 


\subsection{Princípios de extrapolação}

Quando a mistura como um todo não foi testada para determinar seu potencial mutagênico, mas há dados suficientes sobre os ingredientes individuais e misturas similares testadas para caracterizar adequadamente os perigos da mistura, esses dados podem ser usados de acordo com os princípios de extrapolação descritos abaixo.

\section{Diluição}

Se a mistura teste é diluída com um diluente que não se espera que afete o potencial mutagênico de outros ingredientes, então a nova mistura diluída pode ser classificada como equivalente a mistura original.

\section{Lote}

O potencial mutagênico de um lote de produção de uma mistura podem ser assumidas como substancialmente equivalente àquele de um outro lote de produção do mesmo produto comercial, quando produzido pelo mesmo fabricante ou sob seu controle, a menos que haja razão para acreditar que há variação significativa, de modo que a mutagenicidade em células germinativas do lote tenha mudado. Se isso ocorrer, é necessária uma nova classificação.

\section{Misturas substancialmente similares}

Considerando-se o seguinte:

a) duas misturas:

(i) $A+B$;

(ii) $\mathrm{C}+\mathrm{B}$;

b) a concentração do ingrediente $B$ é essencialmente a mesma nas duas misturas;

c) a concentração do ingrediente $A$ na mistura (i) é igual à do ingrediente $C$ na mistura (ii);

d) dados de mutagenicidade para A e B estão disponíveis e são essencialmente equivalentes, ou seja, são da mesma categoria de perigo e não é esperado que 
afetem a mutagenicidade de $B$.

Se a mistura (i) ou (ii) já foi classificada por meio de ensaios, então a outra mistura pode ser classificada na mesma categoria de perigo.

Classificação de misturas quando existem dados disponíveis para todos os ingredientes ou apenas para alguns

Uma mistura deve ser classificada para mutagenicidade quando pelo menos um de seus ingredientes esteja classificado para tais perigos e esteja acima dos valores de limite de corte de $0,1 \%$.

Para informações mais detalhadas de classificação para Mutagenicidade para células germinativas, consultar o capítulo 3.5 do GHS.

O Fluxograma 19 apresenta os passos para classificação de uma mistura em Mutagenicidade para células germinativas. 


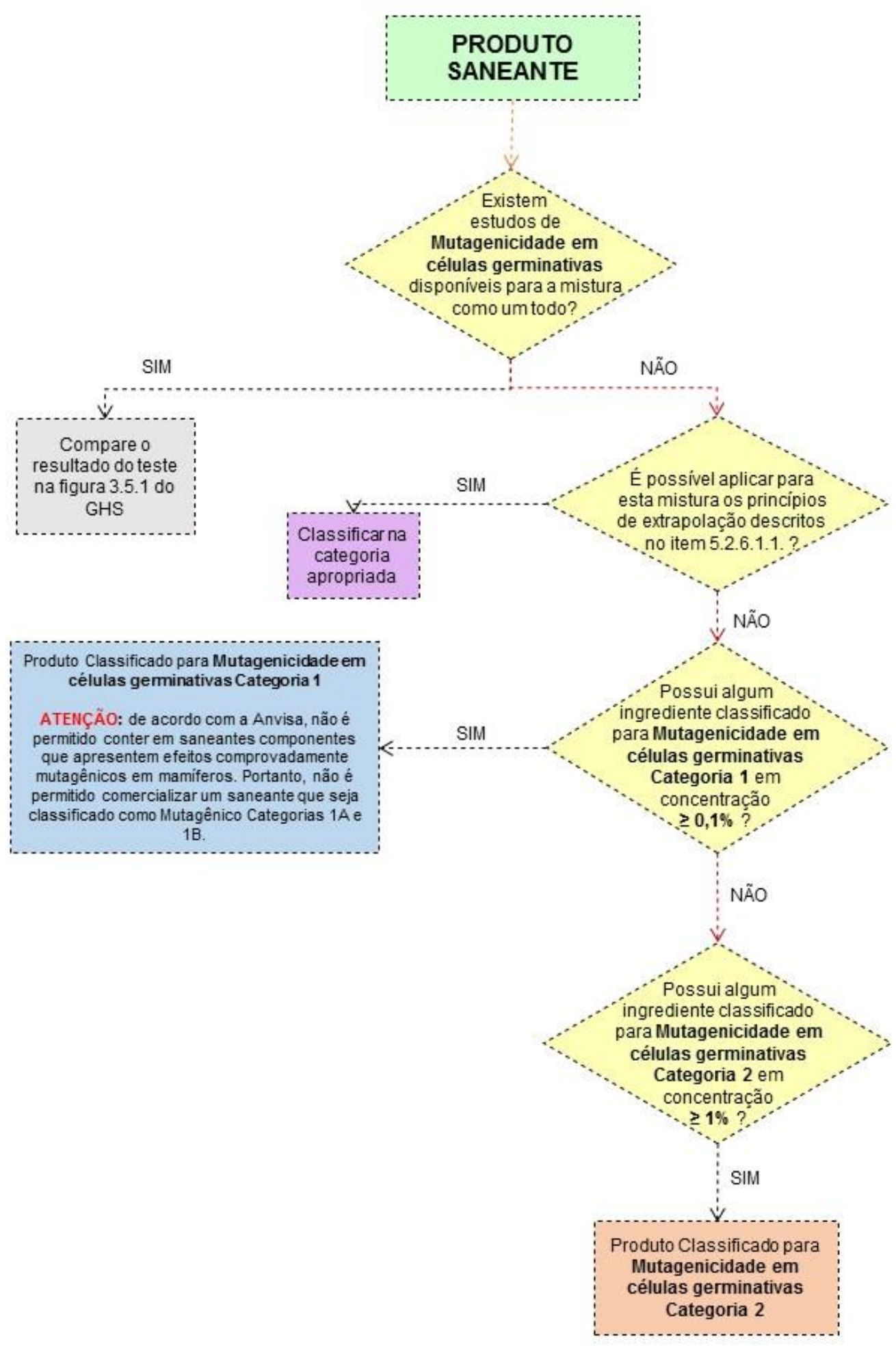

Fluxograma 19 - Decisão lógica para classificação de mutagenicidade em células germinativas 


\subsubsection{Carcinogenidade}

Um produto carcinogênico corresponde àquele que induz a formação de câncer ou promove o aumento da sua incidência. Substâncias e misturas que induzem tumores benignos ou malignos em estudos experimentais em animais também são consideradas como suspeitas ou prováveis de serem um ccarcinogênico para humanos, a menos que haja forte evidência de que o mecanismo de formação do tumor não seja relevante para o homem.

Um produto carcinogênico pode ser classificado como Categoria 1 (subcategorias 1A e 1B) e Categoria 2, porém, para produtos saneantes, a Categoria 1 , com suas respectivas subcategorias, não é aplicável.

Para classificação de substâncias puras, os critérios estão descritos no capítulo 3.5 do GHS, na figura 3.6.1. Já para classificação de uma mistura, os procedimentos seguem o mesmo princípio da classificação em outras classes de perigo, ou seja, primeiro avaliam-se os estudos realizados para a mistura como um todo, se disponíveis. Se não há, utiliza-se os princípios de extrapolação e, caso não se apliquem, por último, utilizam-se os dados disponíveis para os ingredientes.

\subsection{Princípios de extrapolação}

Quando a mistura como um todo não foi testada para determinar seu potencial carcinogênico, mas há dados suficientes sobre os ingredientes individuais e misturas similares testadas para caracterizar adequadamente os perigos da mistura, esses dados podem ser usados de acordo com os princípios de extrapolação descritos abaixo.

\section{Diluição}

Se a mistura teste é diluída com um diluente que não se espera que afete a carcinogenicidade de outros ingredientes, então a nova mistura diluída pode ser classificada como equivalente a mistura original.

\section{Lote}


O potencial carcinogênico de um lote de produção de uma mistura podem ser assumidas como substancialmente equivalente àquele de um outro lote de produção do mesmo produto comercial, quando produzido pelo mesmo fabricante ou sob seu controle, a menos que haja razão para acreditar que há variação significativa, de modo que a carcinogenicidade do lote tenha mudado. Se isso ocorrer, é necessária uma nova classificação.

\section{Misturas substancialmente similares}

Considerando-se o seguinte:

e) duas misturas:

(i) $A+B$;

(ii) $\mathrm{C}+\mathrm{B}$;

f) a concentração do ingrediente B é essencialmente a mesma nas duas misturas;

g) a concentração do ingrediente $A$ na mistura (i) é igual à do ingrediente $C$ na mistura (ii);

h) dados de carcinogenicidade para A e B estão disponíveis e são essencialmente equivalentes, ou seja, são da mesma categoria de perigo e não é esperado que afetem a carcinogenicidade de $B$.

Se a mistura (i) ou (ii) já foi classificada por meio de ensaios, então a outra mistura pode ser classificada na mesma categoria de perigo.

\section{Classificação de misturas quando existem dados disponíveis para todos os ingredientes ou apenas para alguns}

Uma mistura deve ser classificada para carcinogenicidade quando pelo menos um de seus ingredientes esteja classificado para tais perigos e esteja acima dos valores de limite de corte de $0,1 \%$.

Para informações mais detalhadas de classificação para Carcinogenicidade, consultar o capítulo 3.6 do GHS. 
O Fluxograma 20 apresenta os passos para classificação de uma mistura como Carcinogênica.

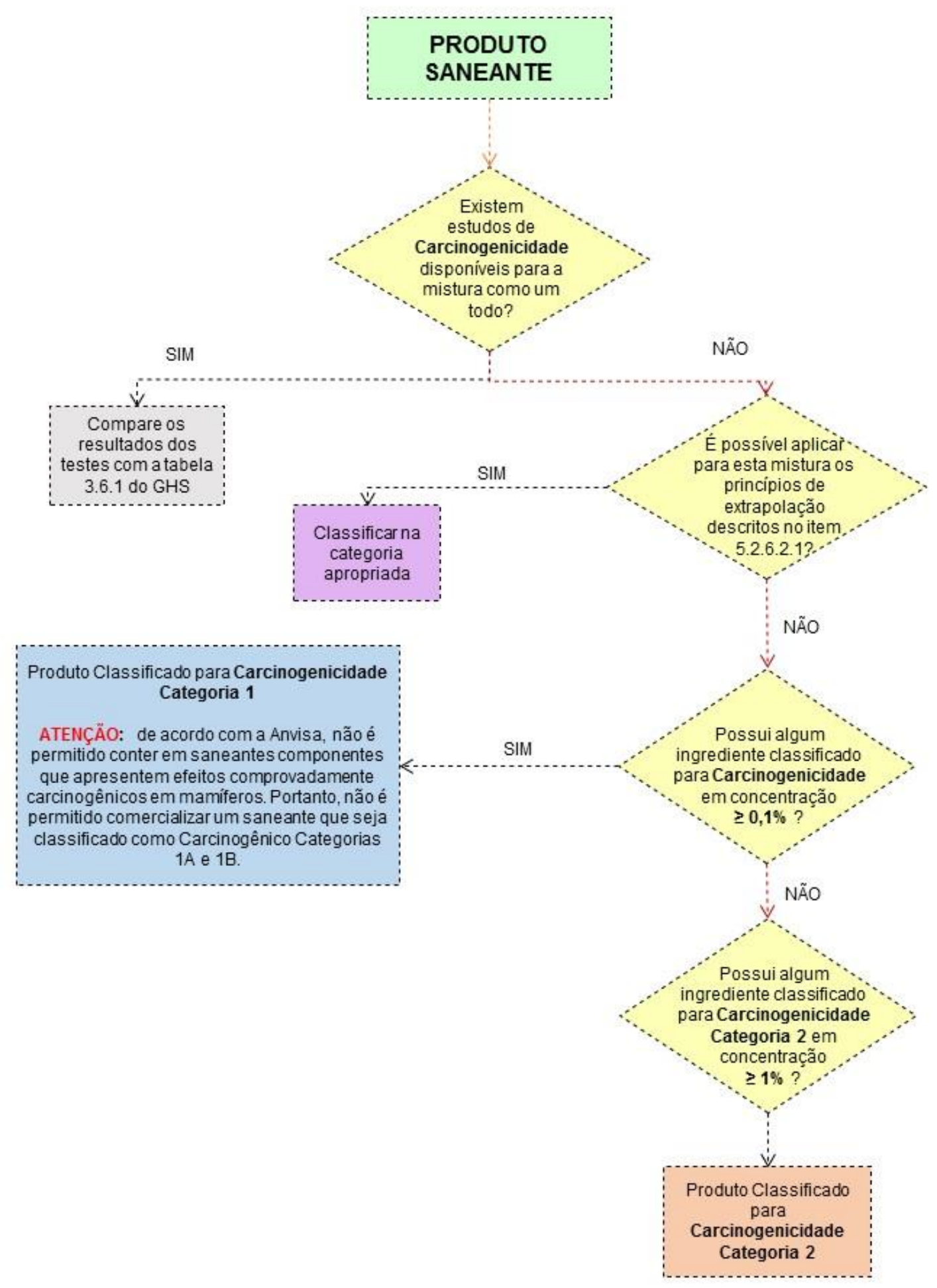

Fluxograma 20 - Decisão lógica para classificação de carcinogenicidade 


\subsubsection{Toxicidade à reprodução}

Na classificação para toxicidade à reprodução incluem os produtos que causam efeitos adversos para a função sexual e/ou para a fertilidade em homens e mulheres adultos e/ou afetem o desenvolvimento dos descendentes. Portanto, no GHS, a toxicidade à reprodução subdivide-se em dois grupos principais:

$\checkmark$ efeitos adversos para a função sexual e a fertilidade;

$\checkmark$ efeitos adversos para o desenvolvimento dos descendentes.

Um produto tóxico à reprodução pode ser classificado como Categoria 1 (subcategorias 1A e 1B) e Categoria 2, porém, para produtos saneantes, a Categoria 1 , com suas respectivas subcategorias, não é aplicável.

Nesta classe de perigo também se inclui uma outra categoria, a de Efeitos sobre a Lactação.

Para classificação de substâncias puras, os critérios estão descritos no capítulo 3.7 do GHS, na figura 3.7.1 (a e b) Já para classificação de uma mistura, os procedimentos seguem o mesmo princípio da classificação em outras classes de perigo, ou seja, primeiro avaliam-se os estudos realizados para a mistura como um todo, se disponíveis. Se não há, utiliza-se os princípios de extrapolação e, caso não se apliquem, por último, utilizam-se os dados disponíveis para os ingredientes.

\subsection{Princípios de extrapolação}

Quando a mistura como um todo não foi testada para determinar seu potencial tóxico à reprodução, mas há dados suficientes sobre os ingredientes individuais e misturas similares testadas para caracterizar adequadamente os perigos da mistura, esses dados podem ser usados de acordo com os princípios de extrapolação descritos abaixo.

\section{Diluição}


Se a mistura teste é diluída com um diluente que não se espera que afete a toxicidade à reprodução de outros ingredientes, então a nova mistura diluída pode ser classificada como equivalente a mistura original.

\section{Lote}

O potencial tóxico à reprodução de um lote de produção de uma mistura podem ser assumidas como substancialmente equivalente àquele de um outro lote de produção do mesmo produto comercial, quando produzido pelo mesmo fabricante ou sob seu controle, a menos que haja razão para acreditar que há variação significativa, de modo que a toxicidade do lote tenha mudado. Se isso ocorrer, é necessária uma nova classificação.

\section{Misturas substancialmente similares}

Considerando-se o seguinte:

a) duas misturas:

(i) $A+B$;

(ii) $\mathrm{C}+\mathrm{B}$;

b) a concentração do ingrediente B é essencialmente a mesma nas duas misturas;

c) a concentração do ingrediente $A$ na mistura (i) é igual à do ingrediente $C$ na mistura (ii);

d) dados de toxicidade para A e B estão disponíveis e são essencialmente equivalentes, ou seja, são da mesma categoria de perigo e não é esperado que afetem a carcinogenicidade de $B$.

Se a mistura (i) ou (ii) já foi classificada por meio de ensaios, então a outra mistura pode ser classificada na mesma categoria de perigo.

Classificação de misturas quando existem dados disponíveis para todos os ingredientes ou apenas para alguns 
Uma mistura deve ser classificada para toxicidade à reprodução quando pelo menos um de seus ingredientes esteja classificado para tais perigos e esteja acima dos valores de limite de corte de $0,1 \%$.

Para informações mais detalhadas de classificação para Carcinogenicidade, consultar o capítulo 3.7 do GHS.

O Fluxograma 21 apresenta os passos para classificação de uma mistura para Toxicidade à Reprodução. 


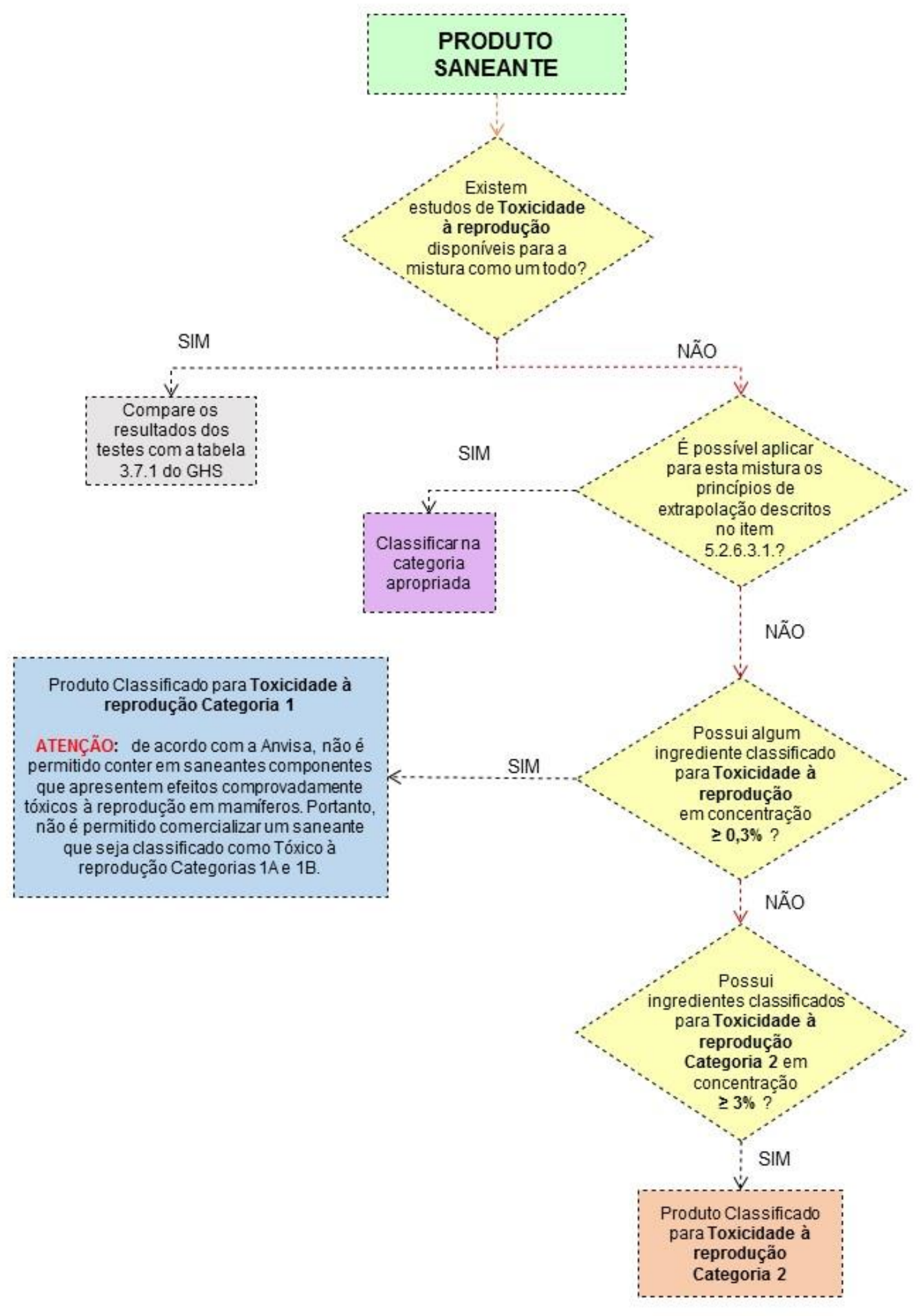

Fluxograma 21 - Decisão lógica para classificação de toxicidade à reprodução 


\subsubsection{Toxicidade para órgãos-alvo específicos - Exposição única}

Se enquadram nessa classe de perigo produtos que produzem toxicidade não letal para certos órgãos-alvo a partir de uma única exposição, ou seja, uma exposição aguda. Estão incluidos também todos os efeitos sobre a saúde que possam provocar alterações funcionais, sejam estas reversíveis ou irreversíveis, imediatas ou retardadas. A avaliação deve levar em consideração não só as mudanças significativas em um único órgão ou sistema biológico, mas também as alterações generalizadas de caráter menos grave envolvendo vários órgãos.

Esta é uma classe de perigo na qual muitos produtos saneantes podem ser enquadrados. Dentre os órgãos afetados estão, por exemplo: Sistema nervoso central, o qual pode ser efetado causando efeitos narcóticos, com sintomas como tontura, fraqueza, enjôo, formigamento, falta de coordenação. Sistema respiratório, o qual pode ter efeitos irritantes caracterizados por vermelhidão, edema, prurido e dor e são acompanhados de sintomas como dor, tosse, engasgo e dificuldade respiratória.

Os produtos podem ser classificados nessa classe de perigo entre as Categorias 1, 2 ou 3, dependendo da gravidade dos efeitos causados.

Os critérios detalhados para classificação de substâncias puras nessa classe de perigo se encontram descritos na tabela 3.8.1 do GH.

\subsubsection{Princípios de extrapolação}

Quando a mistura como um todo não foi testada para determinar seu potencial tóxido em certos órgõs-alvo, mas há dados suficientes sobre os ingredientes individuais e misturas similares testadas para caracterizar adequadamente os perigos da mistura, esses dados podem ser usados de acordo com os princípios de extrapolação descritos abaixo.

\section{Diluição}

Se a mistura teste é diluída com um diluente que é classificado para a mesma classe d perigo da mistura original ou em uma categoria inferior do qual não se espera que afete a toxicidade de outros ingredientes, então a nova mistura diluída pode ser classificada como equivalente a mistura original testada. 


\section{Lote}

As propriedades tóxicas de um lote de produção de uma mistura podem ser assumidas como substancialmente equivalente àquele de um outro lote de produção do mesmo produto comercial, quando produzido pelo mesmo fabricante ou sob seu controle, a menos que haja razão para acreditar que há variação significativa, de modo que a sensibilização respiratória do lote tenha mudado. Se isso ocorrer, é necessária uma nova classificação.

\section{Concentração de misturas da categoria mais elevada}

Quando a mistura teste é classificada como Categoria 1 e a concentração do ingrediente classificado nessa categoria é aumentada, a nova mistura deve ser classificada na Categoria 1 sem que sejam necessários testes adicionais.

\section{Interpolação dentro de uma categoria de perigo}

Para três misturas ( $A, B$ e $C$ ) com ingredientes idênticos, em que as misturas $A$ e $B$ tenham sido ensaiadas e estejam na mesma categoria de perigo e a mistura $C$ não testada tenha os mesmos ingredientes toxicologicamente ativos que as misturas A e B em concentrações similares, então assume-se que a mistura C esteja na mesma categoria que $\mathrm{A}$ e $\mathrm{B}$.

\section{Misturas substancialmente similares}

Considerando-se o seguinte:

a) duas misturas:

(i) $A+B$;

(ii) $\mathrm{C}+\mathrm{B}$;

b) a concentração do ingrediente $B$ é essencialmente a mesma nas duas misturas;

c) a concentração do ingrediente $A$ na mistura (i) é igual à do ingrediente $C$ na mistura (ii);

d) Dados de toxicidade para A e C estão disponíveis e são substancialmente equivalentes, isso é, estão classificadas na mesma categoria de perigo e não é esperado que afetem a toxicidade de $B$ 
Se a mistura (i) ou (ii) já foi classificada por meio de ensaios, então a outra mistura pode ser classificada na mesma categoria de perigo.

\section{Aerossóis}

Uma mistura em forma de aerossol pode ser classificada na mesma categoria de perigo que uma mistura testada não na forma de aerossol, desde que a adição do propelente não afete as propriedades sensibilizantes da mistura quando utilizada na forma de aerossol.

Classificação de misturas quando existem dados disponíveis para todos os ingredientes ou apenas para alguns

Uma mistura deve ser classificada como Tóxica para órgãos-alvo específicos Exposição única quando pelo menos um de seus ingredientes estejam classificados para tais perigos e estejam acima dos valores de limite de corte de acordo com a tabela 16 do fluxograma 22.

Para informações mais detalhadas de classificação para Sensibilização respiratória, consultar o capítulo 3.8.1 do GHS.

O Fluxograma 22 apresenta os passos para classificação de uma mistura para Toxicidade para ógãos-alvo específicos - Exposição única e a tabela 16 desse fluxograma apresenta os limites de corte da composição dos ingredientes para classificação nessa classe de perigo. 


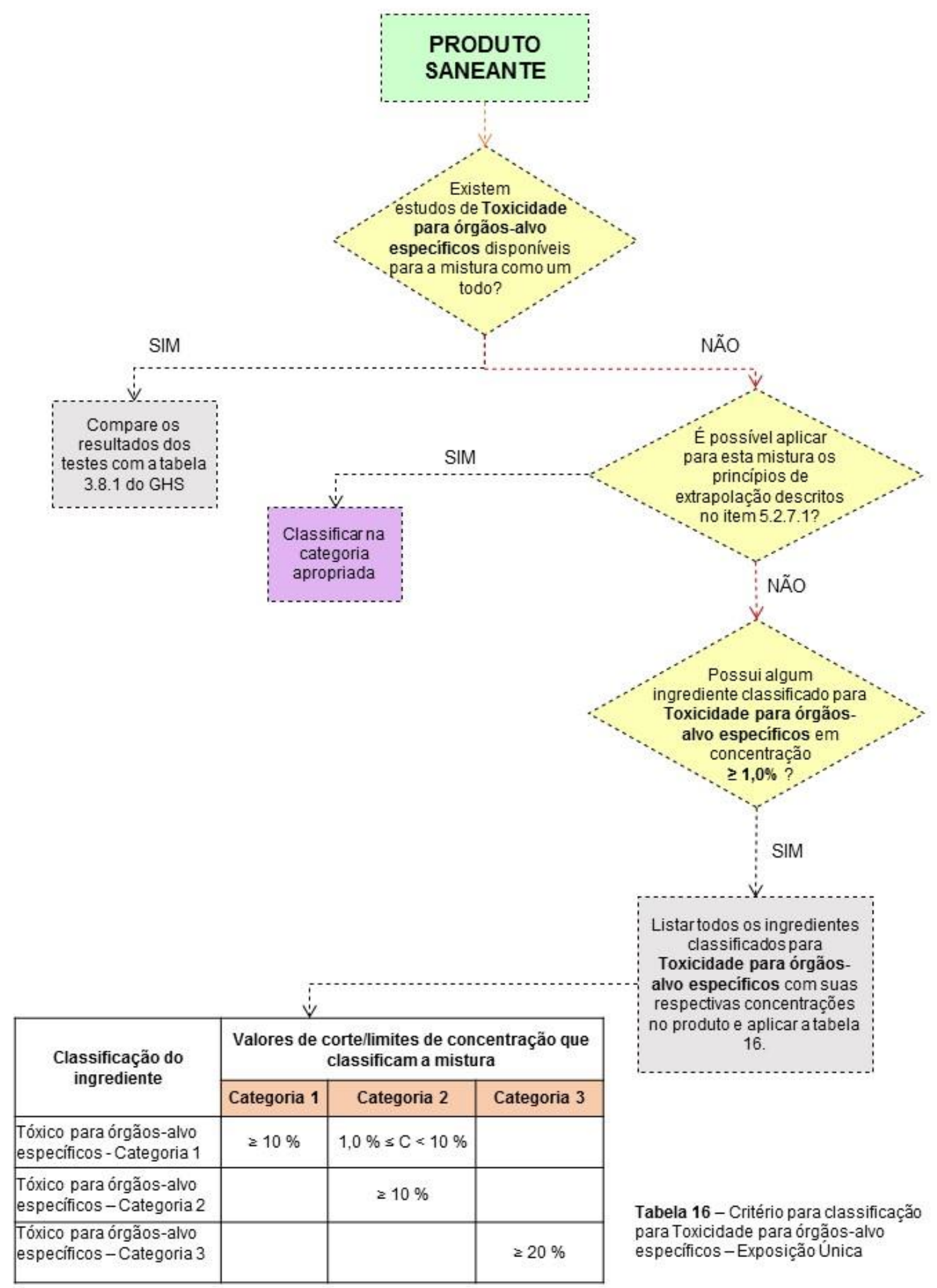

Fluxograma 22 - Decisão lógica para classificação de toxicidade para órgãos-alvo específicos - exposição única 


\subsubsection{Toxicidade para órgãos-alvo específicos - Exposição repetida}

Se enquadram nessa classe de perigo produtos que produzem toxicidade não letal para certos órgãos-alvo a partir de exposições repetidas. Estão incluidos também todos os efeitos sobre a saúde que possam provocar alterações funcionais, sejam estas reversíveis ou irreversíveis, imediatas ou retardadas. A avaliação deve levar em consideração não só as mudanças significativas em um único órgão ou sistema biológico, mas também as alterações generalizadas de caráter menos grave envolvendo vários órgãos.

Os produtos podem ser classificados nessa classe de perigo entre as Categorias 1 ou 2, dependendo da gravidade dos efeitos causados.

\subsubsection{Princípios de extrapolação}

Quando a mistura como um todo não foi testada para determinar seu potencial tóxido em certos órgõs-alvo, mas há dados suficientes sobre os ingredientes individuais e misturas similares testadas para caracterizar adequadamente os perigos da mistura, esses dados podem ser usados de acordo com os princípios de extrapolação descritos abaixo.

\section{Diluição}

Se a mistura teste é diluída com um diluente que é classificado para a mesma classe de perigo da mistura original ou em uma categoria inferior do qual não se espera que afete a toxicidade de outros ingredientes, então a nova mistura diluída pode ser classificada como equivalente a mistura original testada.

\section{Lote}

As propriedades tóxicas de um lote de produção de uma mistura podem ser assumidas como substancialmente equivalente àquele de um outro lote de produção do mesmo produto comercial, quando produzido pelo mesmo fabricante ou sob seu controle, a menos que haja razão para acreditar que há variação significativa, de modo que a sensibilização respiratória do lote tenha mudado. Se isso ocorrer, é necessária uma nova classificação. 


\section{Concentração de misturas da categoria mais elevada}

Quando a mistura teste é classificada como Categoria 1 e a concentração do ingrediente classificado nessa categoria é aumentada, a nova mistura deve ser classificada na Categoria 1 sem que sejam necessários testes adicionais.

\section{Interpolação dentro de uma categoria de perigo}

Para três misturas ( $A, B$ e $C$ ) com ingredientes idênticos, em que as misturas $A$ e $B$ tenham sido ensaiadas e estejam na mesma categoria de perigo e a mistura $C$ não testada tenha os mesmos ingredientes toxicologicamente ativos que as misturas $A$ e $B$ em concentrações similares, então assume-se que a mistura $C$ esteja na mesma categoria que $\mathrm{A}$ e $\mathrm{B}$.

\section{Misturas substancialmente similares}

Considerando-se o seguinte:

e) duas misturas:

(i) $A+B$;

(ii) $\mathrm{C}+\mathrm{B}$;

f) a concentração do ingrediente $B$ é essencialmente a mesma nas duas misturas;

g) a concentração do ingrediente $A$ na mistura (i) é igual à do ingrediente $C$ na mistura (ii);

h) Dados de toxicidade para A e C estão disponíveis e são substancialmente equivalentes, isso é, estão classificadas na mesma categoria de perigo e não é esperado que afetem a toxicidade de $B$

Se a mistura (i) ou (ii) já foi classificada por meio de ensaios, então a outra mistura pode ser classificada na mesma categoria de perigo.

\section{Aerossóis}

Uma mistura em forma de aerossol pode ser classificada na mesma categoria de perigo que uma mistura testada não na forma de aerossol, desde que a adição do propelente não afete as propriedades sensibilizantes da mistura quando utilizada na forma de aerossol. 
Classificação de misturas quando existem dados disponíveis para todos os ingredientes ou apenas para alguns

Uma mistura deve ser classificada como Tóxica para órgãos-alvo específicos Exposição repetida quando pelo menos um de seus ingredientes estejam classificados para tais perigos e estejam acima dos valores de limite de corte de acordo com a tabela 17 do fluxograma 23.

Os critérios detalhados para classificação nessa classe de perigo e outras informações importantes podem ser encontrados no capítulo 3.9 do GHS.

O Fluxograma 23 apresenta os passos para classificação de uma mistura para Toxicidade para ógãos-alvo específicos - Exposição repetida e a tabela 17 desse fluxograma apresenta os limites de corte da composição dos ingredientes para classificação nessa classe de perigo. 


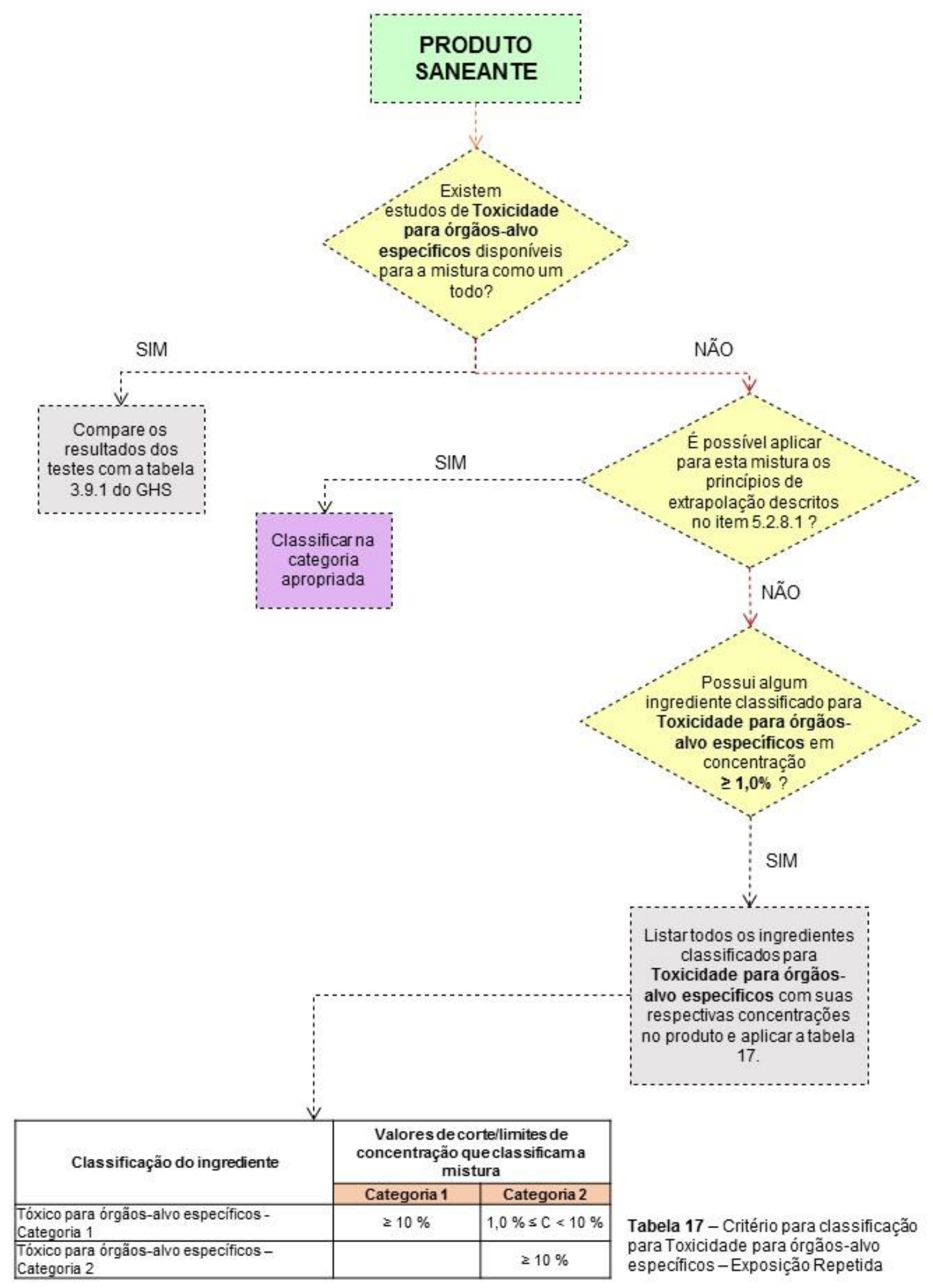

Fluxograma 23 - Decisão lógica para classificação de toxicidade para órgãos-alvo específicos - exposição repetida 


\subsubsection{Perigo por aspiração}

São classificados como perigosos por aspiração os produtos que possuem o potencial de causar aspiração.Aspiração significa a entrada de um produto químico líquido ou sólido diretamente através da cavidade bucal ou nasal, ou indiretamente por regurgitação, na traqueia ou nas vias respiratórias inferiores. A toxicidade por aspiração pode incluir efeitos agudos graves como pneumonia química, lesões pulmonares e aspiração seguida de morte.

A aspiração de inicia no momento da inspiração, quando o produto se aloja na conjunção das vias respiratórias superiores e do trato digestivo na região laringofarínge.

A aspiração de uma substância ou mistura pode ocorrer por uma ingestão após o vômito. Isso pode ter consequências para a rotulagem, principalmente quando, em casos de toxicidade aguda, for considerada a possibilidade de recomendar que, após a ingestão, se provoque vômito. No entanto, quando o produto apresenta um perigo de toxicidade por aspiração, o vômito pode não ser recomendado.

Geralmente possuem o potencial de causar esses dados os produtos que possuem uma viscosidade elevada, que pode ser o caso de óleos ou substâncias viscosas.

\subsubsection{Princípios de extrapolação}

Quando a mistura como um todo não foi testada para determinar seu potencial perigo por aspiração, mas há dados suficientes sobre os ingredientes individuais e misturas similares testadas para caracterizar adequadamente os perigos da mistura, esses dados podem ser usados de acordo com os princípios de extrapolação descritos abaixo.

\section{Diluição}

Se a mistura teste é diluída com um diluente que não é perigoso por aspiração e não espera-se que afete o potencial de outros ingredientes, então a nova mistura diluída pode ser classificada como equivalente a mistura original. Entretanto, a concentração de ingrediente tóxico por aspiração não pode ser menor que $10 \%$. 


\section{Lote}

O potencial tóxico por aspiração de um lote de produção de uma mistura podem ser assumidas como substancialmente equivalente àquele de um outro lote de produção do mesmo produto comercial, quando produzido pelo mesmo fabricante ou sob seu controle, a menos que haja razão para acreditar que há variação significativa, na viscosidade ou concentração no lote que não foi testado. Se isso ocorrer, é necessária uma nova classificação.

\section{Concentração de misturas da categoria 1}

Quando a mistura teste é classificada como Categoria 1 e a concentração do ingrediente classificado nessa categoria é aumentada, a nova mistura deve ser classificada na Categoria 1 sem que sejam necessários testes adicionais.

\section{Interpolação dentro de uma categoria de perigo}

Para três misturas ( $A, B$ e $C$ ) com ingredientes idênticos, em que as misturas $A$ e $B$ tenham sido ensaiadas e estejam na mesma categoria de perigo e a mistura $C$ não testada tenha os mesmos ingredientes toxicologicamente ativos que as misturas $A$ e $B$ em concentrações similares, então assume-se que a mistura $C$ esteja na mesma categoria que $\mathrm{A}$ e $\mathrm{B}$.

\section{Misturas substancialmente similares}

Considerando-se o seguinte:

a) duas misturas:

(i) $A+B$;

(ii) $\mathrm{C}+\mathrm{B}$;

b) a concentração do ingrediente B é essencialmente a mesma nas duas misturas;

c) a concentração do ingrediente $A$ na mistura (i) é igual à do ingrediente $C$ na mistura (ii);

d) Toxicidade por aspiração de A e B estão disponíveis e são essencialmente equi- 
valentes, ou seja, são da mesma categoria de perigo e não é esperado que afetem a carcinogenicidade de $\mathrm{B}$.

Se a mistura (i) ou (ii) já foi classificada por meio de ensaios, então a outra mistura pode ser classificada na mesma categoria de perigo.

\section{Classificação de misturas quando existem dados disponíveis para todos os ingredientes ou apenas para alguns}

Os ingredientes relevantes para classificar uma mistura como tóxica por aspiração são aqueles presentes em concentrações acima de 1\%.

Uma mistura será classificada como Categoria 1 quando a soma da concentração dos ingredientes classificados na Categoria 1 for $\geq 10 \%$ e a mistura tenha uma viscosidade cinemática $\leq 20,5 \mathrm{~mm} / \mathrm{s}^{2}$ medida a $40^{\circ} \mathrm{C}$.

Uma mistura é classificada na Categoria 2 quando a soma da concentração dos ingredientes classificados na Categoria 2 for $\geq 10 \%$ e a mistura tenha uma viscosidade cinemática $\leq 14 \mathrm{~mm} / \mathrm{s}^{2}$ medida a $40^{\circ} \mathrm{C}$.

Os critérios detalhados para classificação nessa classe de perigo e outras informações importantes podem ser encontrados no capítulo 3.10 do GHS.

O Fluxograma 24 apresenta os passos para classificação de uma mistura para Toxicidade por Aspiração. 


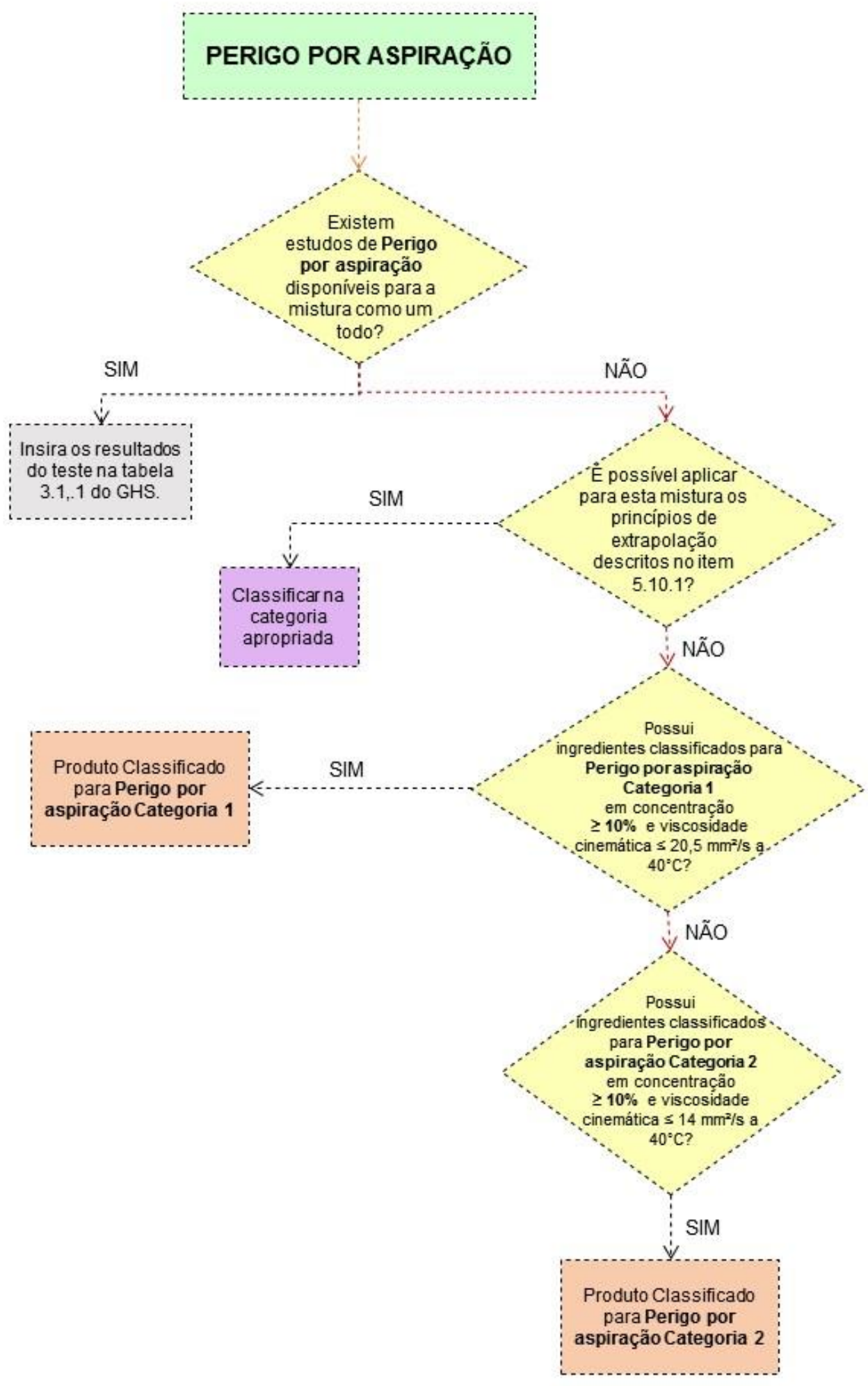

Fluxograma 24 - Decisão lógica para classificação de perigo por aspiração 


\subsection{Perigos ao meio ambiente aquático}

Toxicidade aguda para o meio ambiente aquático é a propriedade intrínseca de um produto de causar efeitos prejudiciais aos organismos aquáticos através de uma curta exposição, enquanto que a toxicidade crônica ao meio ambiente aquático é a propriedde intrínseca de um produto de causar efeitos prejudiiciais aos organismos aquáticos através de uma exposição que é determinada em relação ao ciclo de vida do organismo.

O potencial de toxicidade ao ambiente aquático é avaliado com base nos valores de CL50, CE50 ou CEr50 para organismos aquáticos. Os três valores consistem na concentração do produto que pode matar, causar efeitos adversos e causar efeitos no crescimento em $50 \%$ da população estudada, respectivamente. Para avaliação toxicidade crônica, são avaliados também dados de degradabilidade da substância, potencial de bioacumulação e NOEC (No observed effect concentration), que consiste no valor máximo de concontração do produto em qu não se observa efeitos adversos no organismo estudado. Esses estudos são avaliados em três níveis tróficos diferentes, peixes, crustáceos e algas.

Os critérios detalhados para classificação nestas categorias estão descritos no capítulo 4.1 do GHS. Foram considerados aqui, apenas a classificação de misturas através do método somatório dos ingredientes.

\subsubsection{Perigoso para o meio ambiente aquático - Agudo}

O fluxograma 25 representa os passos para serem tomados para classificação de uma mistura em que se tenham ingredientes classificados para toxicidade aguda ao meio ambiente aquático através do método de somatória. 


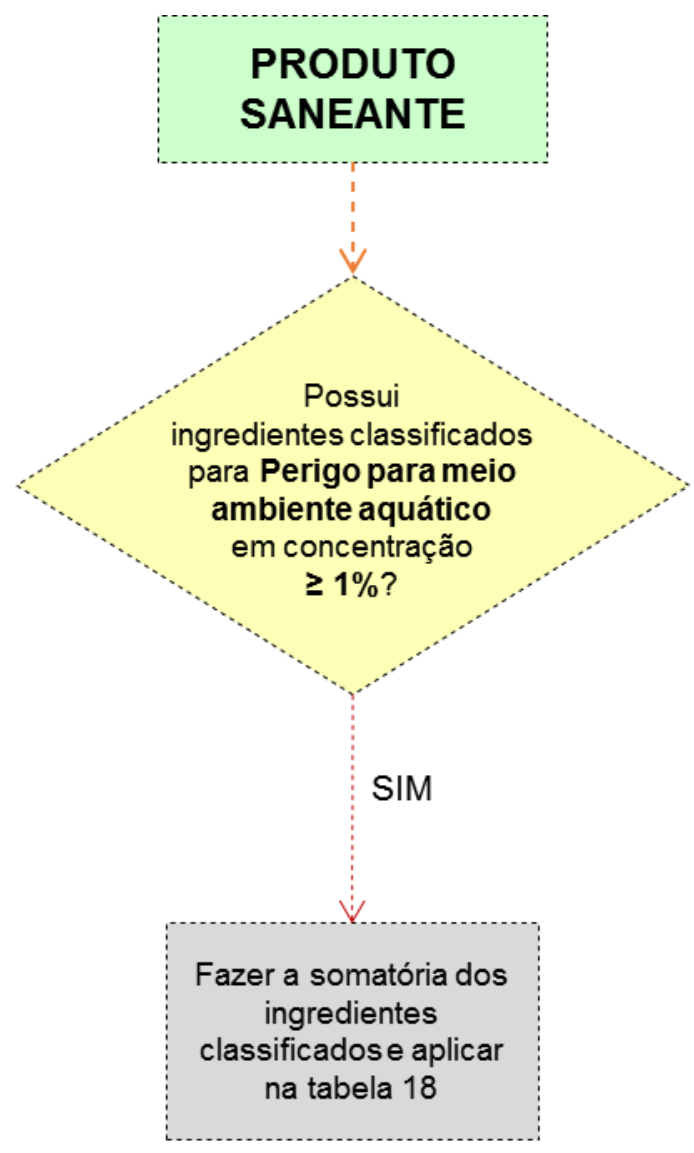

\begin{tabular}{|l|c|c|}
\hline \multicolumn{2}{|c|}{ Soma das concentrações dos ingredientes classificados como: } & A mistura é classificada como: \\
\hline Agudo $1 \times \mathrm{M}^{\mathrm{a}}$ & $\geq 25 \%$ & Aguda 1 \\
\hline$(\mathrm{M} \times 10 \times$ Agudo 1$)+$ Agudo 2 & $\geq 25 \%$ & Aguda 2 \\
\hline$(\mathrm{M} \times 100 \times$ Agudo 1$)+(10 \times$ Agudo 2$)+$ Agudo 3 & $\geq 25 \%$ & Aguda 3 \\
\hline
\end{tabular}

Tabela 18: Critérios para classificação de Perigos ao meio ambiente aquático - Agudo

a : M consiste no fator de multiplicação que é aplicado quando o ingrediente é extremamente tóxico e possui um valores de CL50 inferiores a $1 \mathrm{mg} / \mathrm{L}$

Fluxograma 25 - Decisão lógica para classificação de perigoso para o meio ambiente aquático - agudo 


\subsubsection{Perigoso para o meio ambiente aquático - Crônico}

O fluxograma 26 representa os passos para serem tomados para classificação de uma mistura em que se tenham ingredientes classificados para toxicidade aguda ao meio ambiente aquático através do método de somatória.

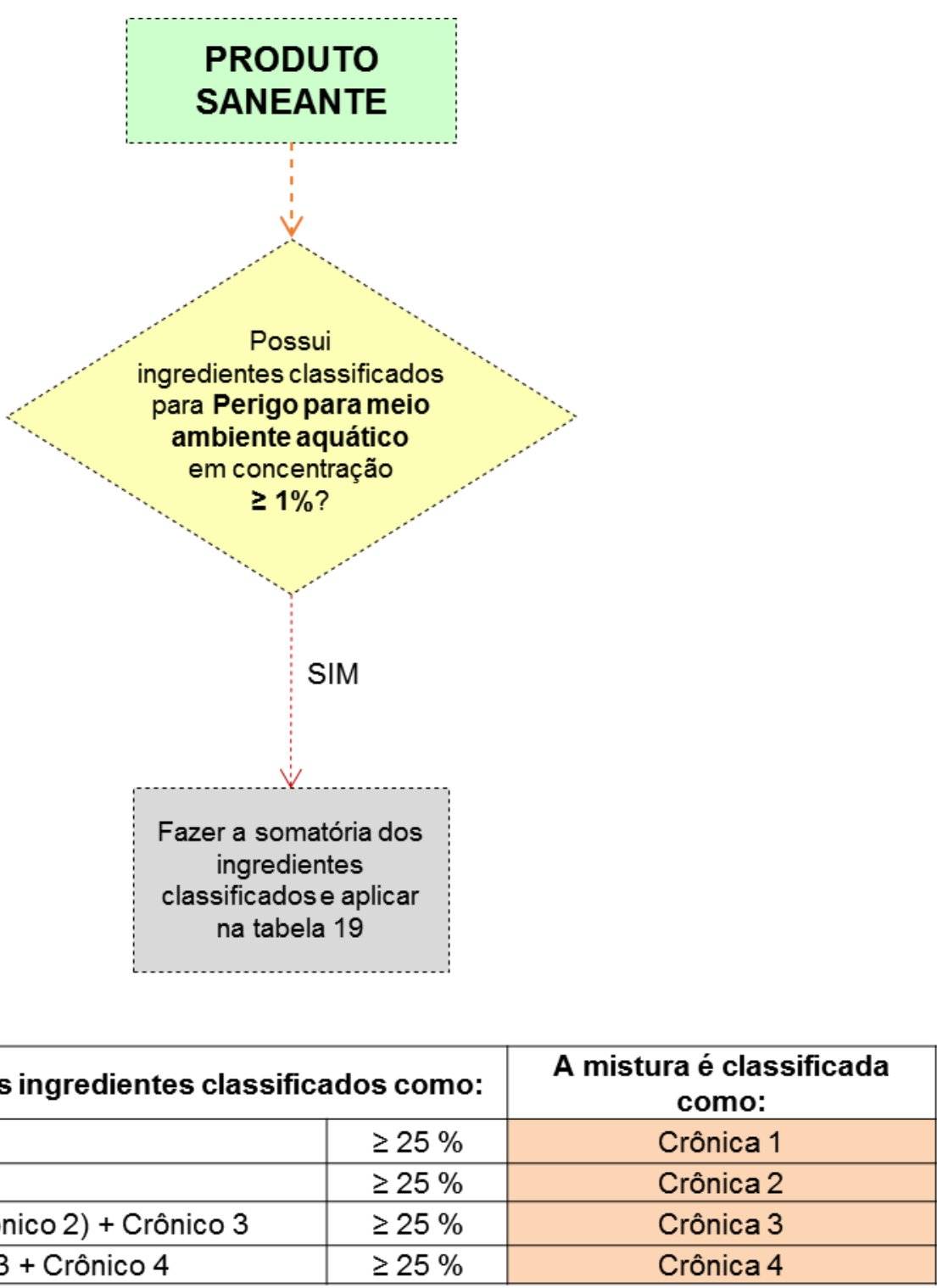

\begin{tabular}{|l|c|c|}
\hline \multicolumn{2}{|c|}{ Soma das concentrações dos ingredientes classificados como: } & $\begin{array}{c}\text { A mistura é classificada } \\
\text { como: }\end{array}$ \\
\hline Crônico $1 \times \mathrm{M}^{\mathrm{a}}$ & $\geq 25 \%$ & Crônica 1 \\
\hline (M x 10 × Crônico 1) + Crônico 2 & $\geq 25 \%$ & Crônica 2 \\
\hline (M x 100 x Crônico 1) + (10 x Crônico 2) + Crônico 3 & $\geq 25 \%$ & Crônica 3 \\
\hline Crônico 1 + Crônico 2 + Crônico 3 + Crônico 4 & $\geq 25 \%$ & Crônica 4 \\
\hline
\end{tabular}

Tabela 19: Critérios para classificação de Perigos ao meio ambiente aquático - Crônico

a : M consiste no fator de multiplicação que é aplicado quando o ingrediente é extremamente tóxico e possui um valores de CL50 inferiores a $1 \mathrm{mg} / \mathrm{L}$

Fluxograma 26 - Decisão lógica para classificação de perigoso para o meio ambiente aquático - crônico 


\section{DISCUSSÕES E CONCLUSÃO}

O GHS é um sistema extremamente complexo e com uma série de particularidades. Sua aplicação requer um conhecimento elevado e uma análise profunda de cada peculiaridade do produto a ser classificado. Além da análise dos requisitos do GHS, o setor de saneantes, em especial, passa por exigências para sua notificação ou registro junto à Anvisa. Portanto, o intuito desse trabalho foi associar os requisitos do GHS e as exigências da Anvisa em um mesmo Roteiro para aplicação na classificação de produtos saneantes.

Utilizando um exemplo para aplicação do roteiro (Anexo I) notou-se que o procedimentto de classificação se tornou mais simples do que aplicar o GHS como um todo devido aos seguintes pontos:

- os fluxogramas do roteiro abrangem apenas as classes de perigo aplicáveis ao setor de saneantes, tornando a consulta aos critérios de classificação mais rápida do que consultar o GHS como um todo;

- as exigências da Anvisa para produtos saneantes já estão compiladas no mesmo fluxograma, evitando, assim, a consulta a dois regulamentos ao mesmo tempo;

- as decisões lógicas contidas nos fluxogramas conteplam vários passos descritos no GHS em um só fluxograma;

- como o fluxograma abrange somente a classificação de misturas, caso se tenha informações confiáveis de todos os ingredientes e não haja nenhuma particularidade para o produto a ser classificado, a classificação se dá de forma simples, fácil e rápida.

Entretanto, foram observadas algumas limitações e imperfeições do roteiro. Devido ao GHS possuir inúmeras particularidades descritas para cada um dos capítulos, muitas delas, a fim de se evitar uma total compilação do livro do GHS, foram desconsideradas para esse roteiro. Apesar de algumas não serem realmente aplicáveis ao setor de saneantes, algumas outras possuem informações específicas que poderiam ter sido melhor incorporadas no roteiro. 
Um exemplo é a diferenciação entre as subcategorias 1A e 1B para classificar uma mistura quando há ingredientes classificados para ambas as subcategorias. $O$ Fator M, utilizado para corroborar com a classificação de Perigodo para o Meio Ambiente aquático também não foi detalhado e pode contrubuir para classificação em outra categoria, quando existente.

Apesar do roteiro integrar em um mesmo fluxograma os requisitos do GHS e as exigências da Anvisa, dentre as 18 classes de perigo aplicáveis para produtos saneantes, somente 4 delas possuem peculiaridades para classificação quando se trata de produto saneante. São elas: Toxicidade Aguda Oral, Mutagenicidade, Carcinogenicidade e Toxicidade à Reprodução. A Corrosão/lrritação à pele possui uma particularidade apenas quando o produto é de Risco I de acordo com classificação da Anvisa. Com isso, percebeu-se que somente para estas 5 classes de perigo há uma diferenciação quando se trata de produto saneante, tendo, para os outros 11 perigos listados no roteiro, critérios de classificação idênticos aos do GHS. esse fato levanta a questão da necessidade de haver um roteiro específico para o setor de saneantes.

O Roteiro abrange as classificações de misturas, considerando que, para isso é preciso estar disponíveis resultados de testes para a mistura como um todo ou haver a classificação e a composição dos ingredientes da mistura. É possível conseguir a classificação das matérias primas da mistura de duas formas; através da FDS enviada pelo fornecedor da substância e/ou consultando as bases de dados internacionais que possuem dados sobre a substância ou fornecem até mesmo a classificação pronta. $O$ impasse é que não é possível confiar totalmente em nenhuma das duas opções. As FDS muitas vezes estão classificadas de forma errônea, outras vezes são muito desatualizadas e não estão nem em conformidade com o GHS. Por outro lado, buscar as informações em bancos de dados requer um longo tempo hábil, uma vez que nem sempre é possível encontrar todas as informações em um único banco de dados. As listas harmonizadas de classificação são específicas para cada uma das regiões e algumas vezes possuem diferenças de classificação de um país para o outro, por isso é necessário verificar e complementar os dados encontrados nestas listas. Com isso concluimos que mesmo que exista um roteiro para auxiliar na classificação, o conhecimento especializado é extremamente importante oara a classificação de um produto de acordo com o GHS. 
Outra limitação que pode ser citada é que esse roteiro tratou apenas da classificação de perigo, que, consideravelmente é a etapa mais complicada, porém, outras informações do GHS como pictogramas, frases de perigo e frases de precaução não foram citadas. Apesar de, depois de realizada a classificação, inserir os pictogramas e as frases de perigo e precaução se tornar um processo fácil, esses dados poderiam ter sido mencionados nesse roteiro para o tornar mais completo.

\section{Conclusão}

O trabalho atingiu o seu objetivo como um todo, criando um modelo de roteiro para aplicação do GHS para o setor de saneantes. Após a aplicação do roteiro em um produto exemplo e após as discussões levantadas, percebeu-se que alguns detalhes poderiam ser melhor incorporados no roteiro. Devido a grande maioria das indústrias de saneantes ser composta por micro ou pequenas empresas, muitas vezes estas não possuem um profissional especializado em classificações do GHS ou nem mesmo possuem recurso para tal, ficando, uma pessoa de outra área da empresa responsável pela classificação do produto e elaboração dos documentos de comunicação de perigo.

Portanto, apesar do roteiro possuir suas limitações e algumas imperfeições, acredita-se que possa contribuir de alguma forma para o setor. Em lugar dos profissionais consultarem o GHS como um todo ou a norma ABNT 14725 que aplica o GHS no Brasil, os quais são documentos extremamente extensos, consultar um guia simplificado, resumido e com particularidades do setor, pode fazer com que as indústrias tenham com esse instrumento uma maneira mais fácil de aplicar o GHS e, assim, contribuir para que as classificações sejam realizadas de uma maneira mais adequada do que são atualmente.

\section{Recomendações}

Para melhorar a comunicação de perigos e riscos em um ambiente de trabalho, recomenda-se investir em um profissional que possa se dedicar totalmente a essa função e em treinamentos dos trabalhadores. 
Para a publicação de um roteiro para o setor de saneantes recomenda-se detalhar melhor algumas particularidades do setor que podem se tornar uma dificuldade. Outros exemplos, contendo cada um um caso específico também contribuirão para o roteiro aqui descrito.

Para complementar o roteiro, pictogramas do GHS, frases de perigo, frases de precaução e detalhamento da elaboração de FDS seria muito contribuidor.

O Brasil é carente de uma lista de substâncias classificadas para ser publicada oficialmente e usada pelos diversos setores de produtos químicos. essa lista facilitaria a classificação das substâncias puras e das próprias misturas, uma vez que, mesmo as indústrias de pequeno porte poderiam fazer a classificação baseando-se na lista e, diminuindo, assim, os possíveis erros de classificação. 


\section{REFERÊNCIAS BIBLIOGRÁFICAS}

ASSOCIAÇÃO BRASILEIRA DAS INDÚSTRIAS DE PRODUTO DE LIMPEZA E AFINS. Anuário Abipla. 8 ${ }^{\text {a }}$ ed. São Paulo: Public Projetos Editoriais, 2013.

ASSOCIAÇÃO BRASILEIRA DAS INDÚSTRIAS DE PRODUTO DE LIMPEZA E AFINS. Anuário Abipla. 10ª ed. São Paulo: Public Projetos Editoriais, 2015.

ASSOCIAÇÃO BRASILEIRA DE NORMAS TÉCNICAS. NBR 14725 - Informações sobre segurança, saúde e meio ambiente. Parte 2: Sistema de classificação de perigo. Rio de Janeiro, 2010.

ASSOCIAÇÃO BRASILEIRA DE NORMAS TÉCNICAS. NBR 14725 - Informações sobre segurança, saúde e meio ambiente. Parte 4: Ficha de informações de segurança de produtos químicos (FISPQ). Rio de Janeiro, 2014.

ALMEIDA, T. N. D. Contaminação por agrotóxicos carbamatos e organofosforados em água para consumo humano de Dourados, MS. Campo Grande: FIOCRUZ, 2010.

Agência Nacional de Vigilância Sanitária. Conceito de Saneantes, Disponível em $<$ http://www.anvisa.gov.br/saneantes/conceito.htm\#O QUE SÃO SANEANTES.> Acesso em: 20 jun. 2016

ANVISA, Agência Nacional de Vigilância Sanitária. Resolução-RDC n 59, de 17 de Dezembro de 2010, 2010.

ARIF, A. A.; DELCLOS, G. L. Association between cleaning-related chemicals and work-related asthma and asthma symptoms among healthcare professionas. Occupational and Environmental Medicine, USA. v. 69, n. 1, p. 35-40, 2012.

AZIZULLAH, A.; RICHTER, P.; HÄDER, D. P. Toxicity assessment of a common laundry detergent using the freshwater flagellate Euglena gracilis. Chemosphere, Germany v. 84, n. 10, p. 1392-1400, 2011.

BAUER, A. Contact dermatitis in the cleaning industry. Current opinion in allergy and clinical immunology, Germany. v. 13, n. 5, p. 521-4, 2013.

BÉDARD, A. et al. Cleaning sprays, household help and asthma among elderly women. Respiratory Medicine, France. v. 108, n. 1, p. 171-180, 2014.

BELLO, A. et al. Quantitative assessment of airborne exposures generated during common cleaning tasks: a pilot study. Environmental health: a global access science source, Bonton (USA). v. 9, n. 1, p. 76, 2010. 
BERNSTEIN, J. A. et al. A combined respiratory and cutaneous hypersensitivity syndrome induced by work exposure to quaternary amines. Journal of Allergy and Clinical Immunology, Ohio p. 257-259, 1994.

BONDI, C. A. M. Applying the precautionary principle to consumer household cleaning product development. Journal of Cleaner Production, Vermont, USA v. 19, n. 5, p. 429437, 2011.

BURGE, P. S; RICHARDSON M.N. Occupational asthma due to indirect exposure to lauryl dimethyl benzyl ammonium chloride used in a floor cleaner. Thorax, United Kingdon v.49, p.842-843, 1994.

BRASIL. Decreto $\mathrm{n}^{\circ} 2.657$, de 3 de Julho de 1998. Diário Oficial da República Federativa do Brasil de 6 de julho de 1998, p. 3, 1998.

CARØE, T. K.; EBBEHØJ, N.; AGNER, T. A survey of exposures related to recognized occupational contact dermatitis in Denmark in 2010. Contact Dermatitis, Copenhagen (Denmark) v. 70, n. 1, p. 56-62, 2014.

CHEMICAL ABSTRACT SERVICE (CAS) - A division of the American Chemical Society. Disponível em: <https://www.cas.org/>. Acesso em 10 jun.2016

CASAS, L. et al. The use of household cleaning products during pregnancy and lower respiratory tract infections and wheezing during early life. International Journal of Public Health, v. 58, n. 5, p. 757-764, 2013.

CHANG, Y.-K. et al. Employee Impact and Attitude Analysis for GHS Implementation in Taiwan. Industrial Health, Japan v. 51, n. 3, p. 353-363, 2013.

CLARK, C R. et al. A GHS-consistent approach to health hazard classification of petroleum substances, a class of UVCB substances. Regulatory Toxicology and Pharmacology, United States. v. 67, n. 3, p. 409-420, 2013.

CORRÊA, L M.LEAL. Saneantes Domissanitários e Saúde : Um estudo sobre a exposição de empregadas domésticas. Rio de Janeiro: UFRJ, 2005.

CORREIA, L. M. et al. Vigilância de efeitos adversos de saneantes em trabalhadores hospitalares: um relato de experiência. Revista Brasileira de Promoção à Saude, Fortaleza. v. 26, n. 3, p. 442-450, 2013.

CÂMARA DOS DEPUTADOS. Conferência das Nações Unidas sobre o meio ambiente e desenvolvimento. Agenda 21. 1995. 
DODSON, R. E. et al. Endocrine disruptors and asthma-associated chemicals in consumer products. Environmental Health Perspectives, Massashusets, USA. v. 120, n. 7, p. 935-943, 2012.

DICKEY,P. Safer Cleaning Products. The Washington Toxics Coalition Fact Sheet, Seatle, WA, 2009 - 2015

DUMAS, O. et al. Cleaning and asthma characteristics in women. American Journal of Industrial Medicine, Europe v. 57, n. 3, p. 303-311, 2014.

EUROPEAN CHEMICAL AGENCY (ECHA). Search for Chemicals. Disponível em: $<$ http://echa.europa.eu/>. Acesso em 15 jun. 2016

EUROPEAN CHEMICAL SUBSTANCES INFORMATION SYSTEM (ESIS). Annex VI to Regulation (EC) No 1272/2008. Disponível em: <http://esis.jrc.ec.europa.eu/>. Acesso em 15 jun. 2016.

EL-GAWAD, H.S.A. Aquatic environmental monitoring and removal efficiency of detergents. Water Science, Egypt. v. 28, n. 1, p. 51-64, 2014.

FEIJTEL, T.C.; PLASSCHE, E.J. VAN DE. Environmental risk characterizaion of 4 major surfactants used in the Netherlands. Dutcch Soap Association (NVZ), Netherlands, 1995

FOLLETTI, I. et al. Asthma and rhinitis in cleaning workers: a systematic review of epidemiological studies. The Journal of Asthma: Official journal of the Association for the Care of Asthma, USA. v. 51, n. 1, p. 18-28, 2014.

FOOK, S. M. L. et al. Avaliação das intoxicações por domissanitários em uma cidade do Nordesse do Brasil. Cad. Saúde Pública, Rio de Janeiro. v. 29, n. 5, p. 1041-1045, 2013.

GERMAN DATABASES ON HAZARDOUS SUBSTANCES (GESTIS). Gestis Substance Database. Disponível em: <http://gestis-en.itrust.de/>. Acesso em 15 jun. 2016.

JAPAN GOVERNMENT. GHS Classification Guidance for Enterprises. [s.I: s.n.].

MATTA, M.E.M.M. Índice De Perigo Para Subsidiar a Aplicação De Lodo De Esgoto Em Solo Agrícola. Tese (Doutorado em Ciências) - Faculdade de Medicina da Universidade de São Paulo, São Paulo, 2011.

MERCOSUL. Programa de apoio ao aprofundamento do processo de integração econômica e desenvolvimento sustentável do MERCOSUL.Lanboratório tecnológico do Uruguai, Uruguai. p. 1-137, 2013. 
MORITA, T.; MORIKAWA, K. Expert Review for GHS Classification of Chemicals on Health Effects. Industrial Health, Japan. v. 49, n. 5, p. 559-565, 2011.

MOUAL, N. LE et al. Use of household cleaning products, exhaled nitric oxide and lung function in females. European Respiratory Journal, France. v. 44, n. 3, p. 816-819, 2014.

NAYAR, G.A. et al. The efficacy of Safety Data Sheets in informing risk based decision making: A review of the aerospace sector. Journal of Chemical Health and Safety, United Kingdon. p. 1-12, 2016.

PECHTER, E. et al. Work-related asthma among health care workers: Surveillance data from California, Massachusetts, Michigan, and New Jersey, 1993-1997. American Journal of Industrial Medicine, Massashussets, New Jersey. v. 47, n. 3, p. 265-275, 2005.

PRESGRAVE, R.F.; CAMACHO, L.A.B.; VILLAS BOAS, M.H.S. Análise dos dados dos Centros de Controle de Intoxicação do Rio de Janeiro, Brasil, como subsídio às ações de saúde pública. Cadernos de Saúde Pública, Rio de Janiro. v. 25, n. 2, p. 401-408, 2009.

PUIATTI, R. Seminário: boas práticas de fabricação e controle de saneantes e e controle de saneantes e cosméticos. Porto Alegre, 2011.

QUIRCE, S.; BARRANCO, P. Cleaning agents and Asthma. Journal of Investigational Allergology and Clinical Immunology, Madrid, Spain.v. 20, n. 7, p. 542-550, 2010.

RODRIGUES, C.D R. Comunicação de Risco e Comunicação Publicitária de Produtos Saneantes Domissanitários. In: XXXII Congresso Brasileiro de Ciências da Comunicação, Caixias do Sul (RS). Anais... Caixias do Sul (RS), 2010

ROSENMAN, K. D. et al. Cleaning products and work-related asthma. Journal of occupational and environmental medicine, USA. v. 45, n. 5, p. 556-563, 2003.

SANTOS, J. A. T. et al. Severity of poisoning by illegal sanitizer. v. 105, p. 247-254, Florianópolis: Texto \& Contexto Enfermagem, 2011.

SISTEMA NACIONAL DE INFORMAÇÕES TOXICOLÓGICAS (SINITOX). Casos Registrados de Intoxicação Humana por Agente Tóxico e Faixa Etária. Brasília: MS; 2013.

SULEIMAN, A.M.; SVENDSEN, K.V.H. Are Safety Data Sheets for Cleaning Products Used in Norway a Factor Contributing To the Risk of Workers Exposure To Chemicals ? International Journal of Occupational Medicine and Environmental Health,Oslo, Norway. v. 27, n. 5, p. 840-853, 2014. 
TANAKA, Mirtha Susana Yamada. Classificação toxicológica dos agrotóxicos e comunicação de perigos e riscos à saúde humana no Brasil: a regulamentação atual e o GHS. 2013. Dissertação de Mestrado em Toxicologia, Universidade Estadual de Londrina, Londrina. 2013.

UNITED NATIONS. Globally Harmonized System of Classification and Labelling of Chemicals (GHS).6th ed. rev. New York; Geneva: United Nations, 2015.

VIZCAYA, D. et al. Functional and biological characteristics of asthma in cleaning workers. Respiratory Medicine, v. 107, n. 5, p. 673-683, 2013.

WALLAU, W.M.; JÚNIOR,J.A.S. O Sistema Globalmente Harmonizado de Classificação e Rotulagem de Produtos Químicos (GHS) - Uma introdução para sua aplicação em laboratórios de ensino e pesquisa acadêmica. Química Nova, Pelotas (RS) v. 36, n. 4, p. 607 $-617,2013$.

WILLEY, R. J. Understanding a safety data sheet (SDS) in regards to process safety. Procedia Engineering, USA. v. 45, n. March, p. 857-867, 2012.

WOLKOFF, P. et al. Risk in cleaning: Chemical and physical exposure. Science of the Total Environment, Europe. v. 215, n. 1-2, p. 135-156, 1998.

WORKPLACE SAFETY \& PREVENTION SERVICES; OCCUPATIONAL HEALTH CLINICS FOR ONTARIO WORKERS. Work-related Asthma: Preventing Work-related Asthma in the Cleaning Industry. Ontario, 2010 


\section{ANEXO I - Exemplo de Aplicação do Roteiro}

Para aplicação do Roteiro apresentado nesse trabalho, foi escolhida como exemplo a concentração típica de um produto desinfetante que está listada na figura 6 (WOLKOFF et al., 1998), desse trabalho. IMPORTANTE: as informações contidas aqui foram totalmente idealizadas afim de se criar um exemplo didático e de fácil compreensão.

10 PASSO: Reunir informações sobre o produto que deseja classificar

Produto a ser classificado: DESINFETANTE XLY

- Propriedades físico-químicas da mistura como um todo

Estado Físico: Líquido

Ponto de Fulgor: $120^{\circ} \mathrm{C}$

Ponto de ebulição: $165^{\circ} \mathrm{C}$

- Resultados de ensaios laboratoriais, se disponíveis

Não há.

- Informações sobre os componentes do produto

Composição:

\begin{tabular}{|l|c|c|}
\hline \multicolumn{1}{|c|}{ Substância } & Número CAS & Concentração (\%) \\
\hline EDTA (ácido etilenodiamino tetra-acético) & $60-00-4$ & 25 \\
\hline Dodecilbenzeno sulfonato de sódio & $25155-30-0$ & 8 \\
\hline 2-propanol & $67-63-0$ & 5 \\
\hline Hidróxido de sódio & $1310-73-2$ & 2 \\
\hline Ácido cítrico & $77-92-9$ & 2 \\
\hline Metassilicato de sodio & $6834-92-0$ & 1 \\
\hline Hipoclorito de sódio & $7681-52-9$ & 0,5 \\
\hline
\end{tabular}




\begin{tabular}{|l|c|c|}
\hline Oléo citrus & $8008-56-8$ & 0,5 \\
\hline Água & & 56 \\
\hline
\end{tabular}

Através dos número CAS dos ingredientes, foram buscadas as classificações de cada um deles em bancos de dados internacionais, como ECHA, GESTIS, TOXNET (estas informações também podem ser obtidas através das FDS/FISPQ dos fornecedores da substância).

EDTA $(60-00-4)$

Lesões oculares graves//rritação ocular - Categoria 2

\section{DODECILBENZENO SULFONATO DE SÓDIO (25155-30-0)}

Toxicidade Aguda Oral - Categoria 4

Corrosão/Irritação à pele - Categoria 2

Lesões oculares graves/Irritação Oculat - Categoria 1

Toxicidade para órgãos-alvo específicos - Exposição Única - Categoria 3

Perigoso ao meio ambiente aquático - Agudo - Categoria 2

\section{2-PROPANOL (67-63-0)}

Líquido Inflamável - Categoria 2

Lesões oculares graves/Irritação Ocular - Categoria 2

Toxicidade para órgãos-alvo específicos - Exposição Única - Categoria 3

\section{HIDRÓXIDO DE SÓDIO (1310-73-2)}

Corrosivo para metais

Corrosão/Irritação à pele - Categoria $1 \mathrm{~A}$

Lesões oculares graves/Irritação ocular - Categoria 1

\section{ÁCIDO CÍTRICO (77-92-9)}

Toxicidade Aguda Oral - Categoria 5 
Lesões oculares graves//rritação ocular - Categoria 2

Perigoso ao meio ambiente aquático - Agudo - Categoria 3

\section{METASSILICATO DE SODIO (6834-92-0)}

Toxicidade Aguda Oral - Categoria 4

Corrosão/Irritação à pele - Categoria 1B

Lesões oculares graves//rritação ocular - Categoria 1

Toxicidade para órgãos-alvo específicos - Exposição Única - Categoria 3

\section{HIPOCLORITO DE SÓDIO (7681-52-9)}

Corrosão/Irritação à pele - Categoria 1B

Lesões oculares graves//rritação ocular - Categoria 1

Perigoso ao meio ambiente aquático - Agudo - Categoria 3

\section{OLÉO CITRUS (8008-56-8)}

Líquido Inflamável - Categoria 3

Toxicidade Aguda Oral - Categoria 5

Toxicidade Aguda Dérmica - Categoria 5

\section{PASSO: Verificar quais dos ingredientes estão abaixo das concentrações de corte-limite}

Analisando todos os ingredientes do produto, com seu respectivos perigos e aplicando a tabela 7, de limites de corte, conclui-se que, o ingredientes Óleo Citrus pode se desconsiderado do cálculo de perigo da mistura para Toxicidade Dérmica, uma vez que sua concentração (0,5\%) está abaixo dos limites de corte estabelecidos para Toxicidade Aguda.

\section{PASSO: Aplicar os fluxogramas}


Os primeiros fluxogramas a serem aplicados serão os dos perigos físicos, utilizando as propriedades físico-químicas do produto desinfetante.

\section{Fluxograma: Líquidos Inflamáveis}

Temos disponíveis o Ponto de Fulgor $\left(120^{\circ} \mathrm{C}\right)$ e o Ponto de Ebulição $\left(165^{\circ} \mathrm{C}\right)$ do produto. Aplicando o fluxograma de líquidos inflamáveis e inserindo esses valores na tabela 1, conclui-se que o produto não será classificado como Líquido Inflamável.

Continuando a aplicação dos outros Fluxogramas de perigos físicos, pode-se descartar o de Líquidos Oxidantes pois não há nenhuma informação disponível a esse respeito para o produto em questão. As classificações para Sólido Oxidante e Aerossol não se aplicam devido ao estado do produto ser líquido e não estar na forma de aerossol.

Na sequência, há o fluxograma de Corrosivo para os metais. Apesar do produto conter um ingrediente classificado como Corrosivo para os metais (hidróxido de sódio), esse está em uma concentração muito baixa (2\%) e o perigo de corrosividade não será herdado para a mistura. Em casos em que ingredientes classificados para esse perigo estejam em concentrações relevantes, é necessário realizar testes para comprovar a classificação.

\section{Fluxograma 9 - Toxicidade Aguda Oral}

Partindo agora para os perigos à saúde, a primeira classe de perigo a ser analisada é a Toxicidade Aguda. Há 4 ingredientes classificados para esse perigo:

- Dodecilbenzeno sulfonato de sódio (8\%)

Toxicidade aguda oral - categoria 4

- Ácido cítrico (2\%)

Toxicidade aguda oral - categoria 5

- Metassilicato de sodio (1\%)

Toxicidade aguda oral - categoria 4

- Oléo citrus $(0,5 \%)$ 
Toxicidade aguda oral - categoria 5

Foxicidade aguda dérmica - categoria 5 - desconsiderado pelo valor de concentração na mistura estar abaixo dos limites de corte para Toxicidade Aguda (1\%)

Como não há dados do valor de DL50 específica para cada um dos ingredientes, o valor foi estimado de acordo com a tabela 8. Portanto:

Toxicidade Aguda Oral - Categoria $4=500 \mathrm{mg} / \mathrm{kg}$ de peso corpóreo

Toxicidade Aguda Oral - Categoria $5=2500 \mathrm{mg} / \mathrm{kg}$ de peso corpóreo.

A partir desses valores, aplicou-se a fórmula 1 para descobrir o valor de ETAm da mistura. Usou-se aqui, a fórmula 1b, uma vez que a soma da concentração dos ingredientes em que não se sabe o valor de DL50 é maior do que $10 \%$.

Aplicando a fórmula:

$$
\begin{gathered}
\frac{100}{E T A_{m}}=\sum_{n} \frac{C_{i}}{E T A_{i}} \\
\frac{100}{E T A_{m}}=\sum \frac{8}{500}+\frac{2}{2500}+\frac{1}{500}+\frac{0,5}{2500}
\end{gathered}
$$

$E T A m=5.319 \mathrm{mg} / \mathrm{Kg}$

Aplicando esse valor de ETA na tabela 6 do fluxograma 9, concluiu-se que o produto não é classificado para Toxicidade Aguda Oral. 
A Toxicidade Aguda Dérmica não precisa ser avaliada, uma vez que o único ingrediente classificado para essa classe de perigo (óleo citrus) está abaixo do valor de limite de corte para Toxicidade Aguda (1\%).

A Toxicidade Aguda Inalatória não será avaliada pois não há ingrediente classificado para essa classe de perigo.

\section{Fluxograma 15 - Corrosão/Irritacão à pele}

Levantando agora os produtos que são classificados para corrosão/irritação à pele, temos que:

\section{DODECILBENZENO SULFONATO DE SÓDIO (8\%)}

Corrosão/Irritação à pele - Categoria 2

HIDRÓXIDO DE SÓDIO (2\%)

Corrosão/Irritação à pele - Categoria $1 \mathrm{~A}$

METASSILICATO DE SODIO (1\%)

Corrosão/Irritação à pele - Categoria 1B

\section{HIPOCLORITO DE SÓDIO (0,5\%)}

Corrosão/Irritação à pele - Categoria 1B

Somando a concentração dos ingredientes classificados como Categoria 1 temos 3,5\% ( $2 \%$ do hidróxido de sódio, $1 \%$ do metassilicato de sódio e $0,5 \%$ do hipoclorito de sódio). Aplicando esse valor na tabela 12 no fluxograma 15, obteve-se a Categoria 2 para a mistura.

O valor de $8 \%$ do ingrediente dodecil benzeno sulfonato de sódio quando aplicado na tabela também resultou na Categoria 2. 
Com estas duas aplicações, concluimos que o produto é classificado para Corrosão/Irritação à pele - Categoria 2.

\section{Fluxograma 16 - Lesões oculares graves/Irritação ocular}

Partindo agora para outra classe de perigo encontrada entre os ingredientes do desinfetante, levantou-se os ingredientes classificados para lesões oculares graves/irritação ocular.

EDTA $(25 \%)$

Lesões oculares graves/Irritação ocular - Categoria 2

\section{DODECILBENZENO SULFONATO DE SÓDIO (8\%)}

Lesões oculares graves//rritação Oculat - Categoria 1

2-PROPANOL (5\%)

Lesões oculares graves//rritação Ocular - Categoria 2

HIDRÓXIDO DE SÓDIO (2\%)

Lesões oculares graves//rritação ocular - Categoria 1

ÁCIDO CÍTRICO (2\%)

Lesões oculares graves//rritação ocular - Categoria 2

METASSILICATO DE SODIO (1\%)

Lesões oculares graves//rritação ocular - Categoria 1

HIPOCLORITO DE SÓDIO (0,5\%)

Lesões oculares graves//rritação ocular - Categoria 1 
A partir desse levantamento concluiu-se que há na mistura $11,5 \%$ de ingredientes classificados na Categoria 1 e $32 \%$ de ingredientes classificados na Categoria 2.

Para analisar essa categoria de perigo também é possível a classificação de corrosão à pele $(3,5 \%)$.

Portanto, analisando a tabela 13 do fluxograma 16, com base em 3,5\% de ingredientes corrosivos para a pele e $11,5 \%$ de ingredientes capazes de provocar lesões oculates graves, conclui-se que o desinfetante será classificado para Lesões oculares graves/Irritação ocular - Categoria 1.

\section{Fluxograma 22 - Toxicidade para órgãos-alvo específicos - Exposição Única}

Três ingredientes são classificados para essa classe de perigo. São eles: DODECILBENZENO SULFONATO DE SÓDIO (8\%)

Toxicidade para órgãos-alvo específicos - Exposição Única - Categoria 3

2-PROPANOL (5\%)

Toxicidade para órgãos-alvo específicos - Exposição Única - Categoria 3

METASSILICATO DE SODIO (1\%)

Toxicidade para órgãos-alvo específicos - Exposição Única - Categoria 3

Somando a concentração dos ingredientes classificados para essa classe de perigo, temos um total de $14 \%$. Avaliando a tabela 16 do fluxograma 22, observou-se que, para ser classificada, a mistura deveria ter, no mínimo, 20\% de ingredientes classificados para essa classe de perigo.

Fluxograma 25 - Perigoso ao ambiente aquático - Agudo 
O último fluxograma aplicado para esse produto desinfetante foi o de perigoso para o meio ambiente aquático agudo, pois dentre os seus ingredientes, há 3 ingredientes classificados para essa classe de perigo:

\section{DODECILBENZENO SULFONATO DE SÓDIO (8\%)}

Perigoso ao meio ambiente aquático - Agudo - Categoria 2

\section{ÁCIDO CÍTRICO (2\%)}

Perigoso ao meio ambiente aquático - Agudo - Categoria 3

\section{HIPOCLORITO DE SÓDIO $(0,5)$}

Perigoso ao meio ambiente aquático - Agudo - Categoria 3

Aplicando a tabela 18 do fluxograma 25, considerando que há $8 \%$ de ingrediente classificado para Categoria 2 e 2,5\% para Categoria 3 e que não há valores de CL50 disponíveis, multiplicou-se $8 \%$ por 2 e somou-se com 2,5\%.Concluiuse, então, que o produto se classificou para Perigoso ao meio ambiente aquático Agudo - Categoria 3.

Portanto, a classificação para o produto DESINFETANTE XLY será a seguinte:

Nome do produto: DESINFETANTE XLY

Classificação GHS:

Corrosão/Irritação à pele - Categoria 2

Lesões oculares graves/Irritação Ocular - Categoria 1

Perigoso ao meio ambiente aquático - Agudo - Categoria 3 